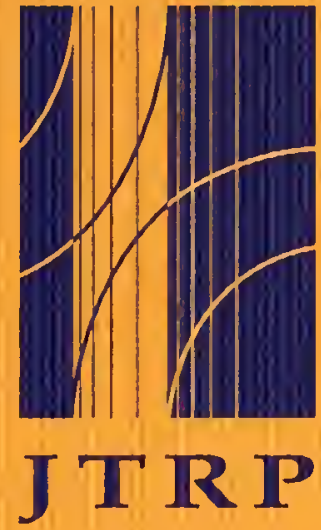

\title{
Joint
}

Transportation

Research

Program

FHWA/IN/JTRP-98/18

Final Report

GEOTECHNICAL PERFORMANCE OF A HIGHWAY EMBANKMENT CONSTRUCTED USING WASTE FOUNDRY SAND

Patrick J. Fox

David G. Mast

November 23, 1998

Indiana

Department

of Transportation

Purdue

University 

Final Report

\title{
FHWA/N/JTRP-98/18
}

\section{GEOTECHNICAL PERFORMANCE OF HIGHWAY EMBANKMENT CONSTRUCTED USING WASTE FOUNDRY SAND}

\author{
Dr. Patrick J. Fox \\ Associate Professor \\ and \\ David G. Mast \\ Staff Engineer \\ School of Civil Engineering \\ Purdue University \\ Joint Transportation Research Program \\ Project No: C-36-36Z \\ File No: 6-14-26 \\ Prepared in Cooperation with the \\ Indiana Department of Transportation and \\ the U.S. Department of Transportation \\ Federal Highway Administration
}

The contents of this report reflect the views of the authors who are responsible for the facts and the accuracy of the data presented herein. The contents do not necessarily reflect the official views or policies of the Federal Highway Administration and the Indiana Department of Transportation. This report does not constitute a standard, specification or regulation.

Purdue University

West Lafayette, Indiana

November 23, 1998 
- 
TECHITCAL REPORT STAVDARD TITLE PAGE

\begin{tabular}{|c|c|c|}
\hline $\begin{array}{l}\text { 1. Report No. } \\
\text { FHWA/N/JTRP-98/18 }\end{array}$ & 2. Government Accession No. & 3. Recipient's Catalog No. \\
\hline \multirow{2}{*}{\multicolumn{2}{|c|}{$\begin{array}{l}\text { 4. Title and Subtitle } \\
\text { Geotechnical Performance of Highway Embankment Constructed Using Waste } \\
\text { Foundry Sand }\end{array}$}} & $\begin{array}{l}\text { 5. Report Date } \\
\text { November } 1998\end{array}$ \\
\hline & & 6. Performing Organization Code \\
\hline \multicolumn{2}{|l|}{$\begin{array}{l}\text { 7. Author(s) } \\
\text { Patrick J. Fox and David G. Mast }\end{array}$} & $\begin{array}{l}\text { 8. Performing Organization Report Nio. } \\
\text { FHWA/NN/JTRP-98/18 }\end{array}$ \\
\hline \multirow{2}{*}{\multicolumn{2}{|c|}{$\begin{array}{l}\text { 9. Performing Organization Name and Address } \\
\text { Joint Transportation Research Program } \\
\text { 1284 Civil Engineering Building } \\
\text { Purdue University } \\
\text { West Lafayette, Indiana } 47907-1284\end{array}$}} & 10. Work Unit No. \\
\hline & & $\begin{array}{l}\text { 11. Contract or Grant Nio. } \\
\text { SPR-2136 }\end{array}$ \\
\hline \multirow{2}{*}{\multicolumn{2}{|c|}{$\begin{array}{l}\text { 12. Sponsoring Agency Name and Address } \\
\text { Indiana Department of Transportation } \\
\text { State Office Building } \\
100 \text { North Senate Avenue } \\
\text { Indianapolis, IN } 46204\end{array}$}} & $\begin{array}{l}\text { 13. Type of Report and Period Covered } \\
\text { Final Report }\end{array}$ \\
\hline & & 14. Sponsuring Agency Code \\
\hline
\end{tabular}

15. Supplementary Notes

Prepared in cooperation with the Indiana Department of Transportation and Federal Highway Administration.

\section{Abstract}

The purpose of this study was to evaluate the use of waste foundry sand (WFS) as a highway embankment material in a full-scale field demonstration project. This evaluation included geotechnical concerns, such as deformation, strength, hydraulic conductivity, and ease of construction. The report presents an introduction and previous research concerning WFS use in highway construction. A geotechnical laboratory testing program characterized the WFS used in the project, which was a waste product of Auburn Foundry, Inc., located in Auburn, Indiana. This study was also a part of the FHWA Priorities Technology Program.

The project site was a $275 \mathrm{~m}$ section of the Country Route 206 highway project near Butler, Indiana. Three sections of the embankment were studied: a section built with clay borrow, a section built with natural sand, and a section built with WFS. The embankment was built during the summer of 1996. This report presents field testing data with regard to vertical and lateral deformations of the WFS embankment, in situ changes in pore pressures in the foundation soils during construction, and the post-construction in situ penetration resistance of the WFS. The performance of the WFS section is compared to that of the clay borrow and natural sand sections of the embankment.

The results of laboratory and field testing of the Auburn Foundry WFS provide general guidelines for the choice of geotechnical parameters for preliminary design of WFS embankments. From a geotechnical perspective, the results indicate that WFS can be used successfully as embankment fill material for full-scale highway projects.

\section{Key Words}

waste foundry sand, highway embankment, geotechnical performance, laboratory testing.
18. Distribution Statement

No restrictions. This document is available to the public through the National Technical Information Service, Springfield, VA 22161
19. Security Classif. (of this report)

Unclassified
20. Security Classic. (of this page)

Unclassified

21. No. of Pages
110

22. Price 
Digitized by the Internet Archive in 2011 with funding from

LYRASIS members and Sloan Foundation; Indiana Department of Transportation 
TABLE OF CONTENTS

Page

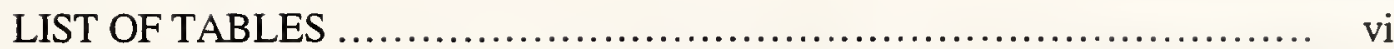

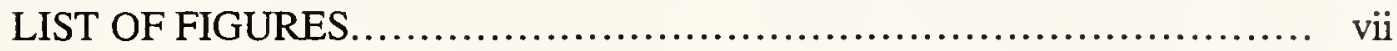

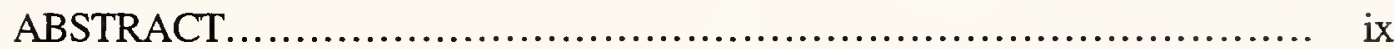

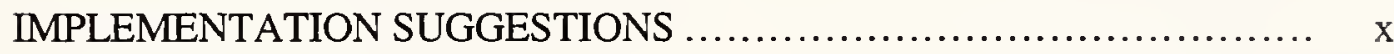

CHAPTER 1: INTRODUCTION........................................ 1

CHAPTER 2: OBJECTIVES.......................................... 3

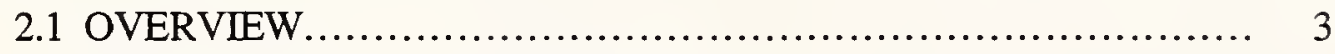

2.2 SPECIFIC RESEARCH OBJECTIVES........................... 3

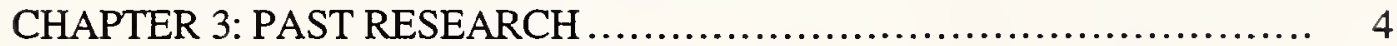

3.1 LABORATORY STUDIES OF WFS ............................. 4

3.1.1 Loss on Ignition ...................................... 4

3.1.2 Shape and Texture of WFS ................................ 4

3.1.3 Clay Lumps and Friable Particles ........................ 5

3.1.4 Compressibility of WFS................................ 5

3.1.5 Resilient Modulus of WFS .................................. 7

3.2 FIELD STUDIES OF WFS EMBANKMENTS .................... 7

CHAPTER 4: LABORATORY TESTING RESULTS ..................... 11

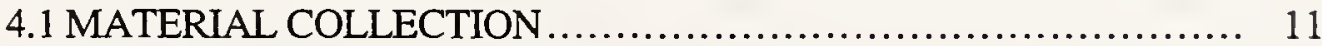

4.2 GRAIN SIZE DISTRIBUTION................................. 11

4.3 SPECIFIC GRAVITY OF SOLIDS ............................ 16

4.4 ATTERBERG LIMITS ........................................... 16

4.5 PROCTOR COMPACTION ...................................... 17 
Page

4.6 VIBRATORY COMPACTION .................................. 21

4.7 CALIFORNIA BEARING RATIO ............................. 21

4.8 HYDRAULIC CONDUCTIVITY.................................. 28

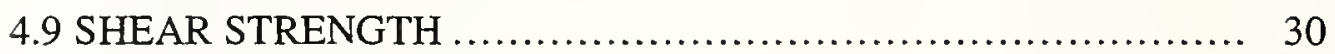

CHAPTER 5: FIELD CONSTRUCTION AND TESTING ................. 38

5.1 PRE-CONSTRUCTION INFORMATION ........................ 38

5.1.1 Project Site Location .................................... 38

5.1 .2 Geology and Subsurface Conditions........................ 38

5.1.3 Embankment Plans and Drawings.......................... 40

5.1.4 Instrument Locations....................................... 40

5.2 CHRONOLOGY OF WFS PROJECT ............................ 44

5.3 FIELD COMPACTION TESTING ................................. 50

5.3.1 Compaction Test Pad at Auburn Foundry Monofill ............. 50

5.3.2 Field Compaction Testing Results.......................... 52

5.3.3 Comparison of Field Compaction Test Methods................ 54

5.4 EMBANKMENT DEFORMATION .............................. 59

5.4.1 Vertical Movement....................................... 59

5.4.1.1 Horizontal Inclinometers ........................ 59

5.4.1.2 Settlement Plates ................................. 64

5.4.2 Lateral Movement..................................... 72

5.4.2.1 Installation of Vertical Inclinometers................ 72

5.4.2.2 Difficulties with Vertical Inclinometers................ 72

5.4.2.3 Lateral Movements after Construction................ 72

5.4.2.4 Sondex Measurements............................. 74

5.5 IN SITU HYDRAULIC CONDUCTIVITY TESTING............... 74

5.6 TOTAL STRESS MEASUREMENTS .......................... 80

5.7 SUBSURFACE PORE PRESSURE MEASUREMENTS ............ 82

5.8 POST CONSTRUCTION STANDARD PENETRATION TESTING. . 82

5.9 DISCUSSION AND OBSERVATIONS ......................... 82

CHAPTER 6: CONCLUSIONS AND RECOMMENDATIONS ............. 86

6.1 CONCLUSIONS ............................................ 86

6.2 RECOMMENDATIONS ....................................... 87 
Page

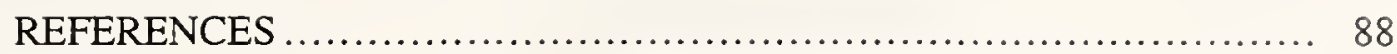

APPENDIX: INDOT SOIL BORING LOGS ......................... 89 


\section{.}


vi

LIST OF TABLES

Table

Page

3.1 Effect of Water Content, Dry Unit Weight, Relative Compaction, and CBR on Resilient Modulus of Green WFS (Javed and Lovell 1994) ... 8

4.1 Geotechnical Laboratory Test Results for Auburn WFS.

12

4.2 CBR Test Results for WFS

27

4.3 Hydraulic Conductivity of WFS

29

4.4 Results of Direct Shear Tests.

37

5.1 2 INDOT HSA Soil Boring for Project Site.

41

5.2 Data from WFS Project Site Compaction Test Section.

56 



\section{LIST OF FIGURES}

Figure

Page

3.1 Compressibility Curves for Dry and Saturated WFS (Javed and Lovell 1994)....

4.1 Grain Size Distributions for Weathered and Fresh WFS ............... 14

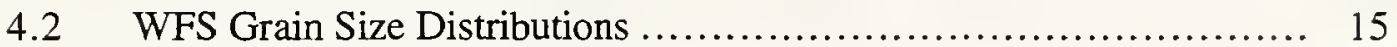

4.3 Proctor Compaction Data for Weathered WFS....................... 18

4.4 Proctor Compaction Curves for Weathered WFS. ..................... 19

4.5 Method A Standard Proctor Curve for Fresh WFS (Sample \#1)....... 20

4.6 Vibratory Compaction Curve for WFS (Sample \#1)............... 22

4.7 CBR Test Results for Unsoaked and Soaked Weathered WFS (Sample \#1).

4.8 CBR Test Results for Unsoaked and Soaked Fresh WFS (Sample \#1).

4.9 CBR Swell Test Results for Fresh WFS (Sample \#1)............... 26

4.10 Direct Shear Test Results For Loose Weathered WFS (Sample \#1)..... 31

4.11 Direct Shear Test Results For Dense Weathered WFS (Sample \#1)..... 32

4.12 Direct Shear Test Results For Loose Fresh WFS (Sample \#1)......... 33

4.13 Direct Shear Test Results For Dense Fresh WFS (Sample \#1). ........ 34

4.14 Failure Envelopes for Loose WFS (Sample \#1) .................... 35

4.15 Failure Envelopes For Dense WFS (Sample \#1) .................. 36

$5.1 \quad$ Project Location and Plan View................................... 39

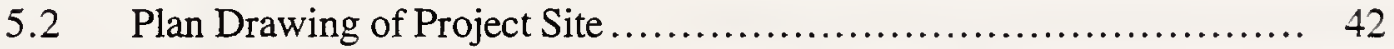

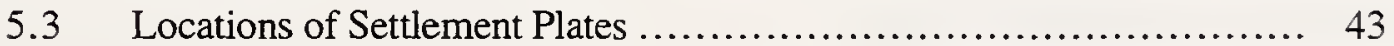

5.4 WFS Geotechnical Instrumentation Locations ........................ 45

$5.5 \quad$ WFS Geotechnical Instruments.................................... 46 
5.6 Chronology of WFS Project ..................................... 47

5.7 Results of Test Pad Construction at Auburn Foundry Monofill ......... 51

$5.8 \quad$ Field and Laboratory Compaction Data for Auburn WFS ............. 53

5.9 Photograph of WFS Compaction Test Section at Project Site........... 55

5.10 Field Measurements of Wet Unit Weight of Auburn WFS ............ 57

5.11 Field Measurements of Dry Unit Weight of Auburn WFS ............ 58

5.12 Field Measurements of Moisture Content of Auburn WFS............. 60

5.13 Settlement of Bottom Horizontal Inclinometer ....................... 62

5.14 Settlement of Top Horizontal Inclinometer ........................ 64

5.15 Definition of Settlement Plate Elevation Differences ................. 65

5.16 (a) Settlement of Clay Borrow Settlement Plates ...................... 66

5.16(b) Elevation Differences for Clay Borrow Settlement Plates ............ 67

5.17(a) Settlement of B-Borrow Settlement Plates ......................... 68

5.17(b) Elevation Differences for B-Borrow Settlement Plates .............. 69

5.18(a) Settlement of WFS South Settlement Plates...................... 70

5.18(b) Elevation Differences for WFS South Settlement Plates............. 71

5.19 Horizontal Displacements of East Vertical Inclinometer. .............. 73

5.20 Horizontal Displacements of West Vertical Inclinometer .............. 75

5.21 SDRI Test of WFS ............................................. 76

5.22 (a) Installation of SDRI.......................................... 78

5.22 (b) SDRI Test ...................................................... 78

5.23 Volumetric Flow Rate vs. Time for SDRI......................... 79

5.24 Total Stress at the Base of the WFS Embankment vs. Time ........... 81

5.25 Subsurface Pore Pressure vs. Time............................... 83

5.26 Standard Penetration Test Results................................. 84 


\begin{abstract}
The purpose of this study was to evaluate the use of waste foundry sand (WFS) as a highway embankment material in a full-scale field demonstration project. This evaluation included geotechnical concerns, such as deformation, strength, hydraulic conductivity, and ease of construction. The report presents an introduction and previous research concerning WFS use in highway construction. A geotechnical laboratory testing program characterized the WFS used in this project, which was a waste product of Auburn Foundry, Inc., located in Auburn, Indiana.
\end{abstract}

The project site was a $275 \mathrm{~m}$ section of the County Route 206 highway project near Butler, Indiana. Three sections of the embankment were studied: a section built with clay borrow, a section built with natural sand, and a section built with WFS. The embankment was built during the summer of 1996 . This report presents field testing data with regard to vertical and lateral deformations of the WFS embankment, in situ hydraulic conductivity of the WFS, accuracy of field compaction testing methods in WFS, total stress on the embankment foundation, changes in pore pressures in the foundation soils during construction, and the post-construction in situ penetration resistance of the WFS. The performance of the WFS section is compared to that of the clay borrow and natural sand sections of the embankment.

The results of laboratory and field testing of the Auburn Foundry WFS provide general guidelines for the choice of geotechnical parameters for preliminary design of WFS embankments. From a geotechnical perspective, the results indicate that WFS can be used successfully as embankment fill material for full-scale highway projects. 


\section{-}




\section{IMPLEMENTATION SUGGESTIONS}

1. Standard material tests can be used to determine the geotechnical properties of WFS.

2. Field compaction of WFS is probably best accomplished using heavy equipment which imparts a kneading action to the surface. Smooth drum and smooth drum vibratory rollers were found to be relatively ineffective in compacting WFS.

3. WFS stockpiles for highway embankment reuse applications should not contain bag house dust or foreign objects such as discarded castings, slag, cores, and welding rods. Foundry operators who wish to reuse WFS should not incorporate these materials into their WFS stream.

4. The nuclear density gage may be used for compaction quality control of WFS in the field provided a suitable correction factor is developed for moisture content using projectspecific materials.

5. Highway embankment construction involving WFS should make provisions to prevent migration of WFS fines off site. Silt fences would typically be used for this purpose.

6. Design of drainage details for WFS embankments should be based on the assumption that compacted WFS is not freely draining, having a hydraulic conductivity on the order of $1 \mathrm{x}$ $10^{-7} \mathrm{~m} / \mathrm{s}$. 
. 


\section{CHAPTER 1: INTRODUCTION}

Waste foundry sand (WFS) is a byproduct of the metal casting process. Binders are added to clean natural sand such that it can maintain the impression of the desired casting while molten metal is poured into the mold. After repeated use, the sand is no longer able to maintain the desired properties during metal pouring. At that point, a portion of the sand is mixed with new materials to store its properties and the rest (WFS) is disposed as solid waste.

The WFS used in this project was produced by the green sand molding process. Details of green sand composition and production are provided by Mast (1997) and Partridge and Alleman (1998). Green sand (which is actually black) is composed of uniform quartz sand (85-95\%), bentonite clay (to provide cohesion, 4-10\%), a volatile coal additive (to prevent casting defects, $2-10 \%$ ), and water (2-5\%). Small quantities of iron oxide are also added to increase strength and prevent erosion of the mold during metal pouring. The defect-prevention additives may include sea coal, cellulose, cereal binders, and sea coal substitutes. Sea coal is a highly volatile bituminous coal which is finely ground and then mixed with the molding sands.

In addition to green sand, which forms the exterior shape of the casting, sand "cores" are used to create void spaces or deep impressions inside the final casting. Cores are prepared separately from the green sand, using either a chemically-bonded or shell-bonded process. Chemically-bonded sands are formed using furan, phenolic urethane, acid-cured no-bake systems, or alkyd and phenolic urethane cold box processes. The organics involved in the production of cores have raised environmental concerns with regard to the beneficial reuse of WFS.

Once the molten metal is poured and cooled, the casting is mechanically shaken to break the cores out of the interior and to remove any excess green sand from the sides. The majority of the green sand and cores are collected and sent to a recycling system. Some of the cores are 
crushed in the recycling process and become part of the green sand system. Small amounts of new sand and additives are added to maintain the proper consistency of the green sand. During this reclamation process, a small fraction of the spent green sand and some cores are removed from the system. This is done to maintain a consistent volume of green sand and to filter out green sand that has been severely burned and will not perform properly. The broken cores and discarded green sand is collectively called waste foundry sand. WFS may also include intact cores, "popcorn slag", bag house dust, discarded castings, and miscellaneous refuse from the foundry. Popcorn slag is a lightweight, glassy material that is formed when the iron slag from the cupola melting process comes into contact with moisture.

Rising disposal costs have generated interest in the beneficial reuse of WFS. The annual generation of WFS in Indiana is estimated at 450,000 tons (INCMA 1992). At a landfill disposal cost of $\$ 26$ to $\$ 52 / \mathrm{m}^{3}$ (not including transportation), a consistent program of WFS reuse could result in a savings of over $\$ 15$ million for Indiana foundries. In Indiana, WFS is classified as a Type I, II, III, or IV waste based on the EP Toxicity Test and the Indiana Department of Environmental Management (IDEM) Foundry Waste Classification Guidelines (Partridge and Alleman 1998). WFS which is categorized as Type I, II, or III must be landfilled in an approved site and may require a detailed disposal plan and permit application. However, Indiana regulations provide for the "...beneficial reuse of foundry sand meeting the Type III category, if the construction reuse is 'legitimate', including the use as pavement base." Type IV solid waste is not subject to the regulations and has minimal requirements for disposal. 


\section{CHAPTER 2: OBJECTIVES}

\subsection{OVERVIEW}

The objective of this project was to assist INDOT in the evaluation of the geotechnical performance of a highway embankment constructed using WFS from the Auburn Foundry. In addition, a laboratory investigation was conducted on the geotechnical properties of the WFS used for construction. This report addresses the geotechnical investigations performed. The companion report for this project (Partridge and Alleman 1998) provides a detailed treatment of the environmental investigations that were conducted as part of the overall project.

\subsection{SPECIFIC RESEARCH OBJECTIVES}

- To conduct a laboratory testing program to investigate the index, compaction, hydraulic, and shear strength properties of Auburn WFS.

- To install instruments and perform field tests to monitor the compaction, deformation, hydraulic conductivity, and penetration resistance of the WFS after placement in the field. Instruments were also installed to monitor deformations and pore pressures in the subsurface.

- To make observations during construction related to the placement of WFS in the field. 
- 


\section{CHAPTER 3: PAST RESEARCH}

\subsection{LABORATORY STUDIES OF WFS}

A major source of laboratory test data for the geotechnical properties of WFS was published by Javed and Lovell (1994) and Javed et al. (1994). This section will be limited to the results of tests which were not performed for this project. Published data that is compared to the test results for this project will be presented in Chapter 4.

\subsubsection{Loss On Ignition}

Javed and Lovell (1994) measured the organic content of WFS using the loss on ignition (LOI) test. Weight loss (percentage of initial dry weight) was calculated after heating the WFS from $110^{\circ} \mathrm{C}$ to $550^{\circ} \mathrm{C}$ in a furnace. The average value for LOI was $5.46 \%$. The LOI values for 14 samples ranged from $2.82 \%$ to $12.06 \%$ and had a standard deviation of $2.85 \%$. Overall, the LOI values were relatively higher for green WFS than cold box and shell-molded process sands. Javed and Lovell suggested that this was due to the presence of combustible additives in the green sand, such as seacoal.

\subsubsection{Shape and Texture of WFS}

Javed and Lovell (1994) studied the shape and texture of green WFS using an optical microscopic. WFS particles were found to be subangular to rounded and relatively rough as compared to natural sands. A flow test was performed to determine the uncompacted void content. This value can be correlated to the particle shape and aggregate texture. The average uncompacted void content for WFS was $50.3 \%$, with a range from $45.1 \%$ to $58.3 \%$ for seven samples. For comparison, a natural sand yielded $43.7 \%$ uncompacted void content. The higher value for green WFS suggests that it has a rougher texture, which the authors conclude is due to the agglomeration of sand with binder and additives. 


\subsubsection{Clay Lumps and Friable Particles}

Javed and Lovell (1994) used an alternative procedure to the ASTM C 142 method for determining the clay lumps and friable particles in WFS. The procedure is described by the American Foundrymen's Society (AFS) and uses material retained on the No. 12 sieve. Two types of lumps were encountered. Lumps associated with molding sand easily disintegrated in water. However, those associated with cores were hard and could not be easily broken. Green WFS had an average of $10.9 \%$ clay lumps and friable particles. However, for five of the seven samples, the average percentage of clay lumps and friable particles was $1.7 \%$, whereas the remaining two samples had values of $44.3 \%$ and $23.3 \%$. The recommendation of Javed and Lovell (1994) was that the harder lumps must be crushed prior to construction use. For embankment fill projects, this crushing may be accomplished by field compaction equipment.

\subsubsection{Compressibility of WFS}

One-dimensional compression tests were performed on $2.54 \mathrm{~cm}$ high, $6.35 \mathrm{~cm}$ diameter specimens in a dense condition. Two specimens were tested dry and two specimens were tested saturated. The saturated specimens were back pressured and soaked for $24 \mathrm{hr}$. prior to testing. Swelling was measured in accordance with ASTM D 4546 Method A, as well as pore pressure changes with time. Control tests were performed on specimens of natural sand for comparison.

Javed and Lovell (1994) found that the generation of excess pore pressures in green WFS specimens was insignificant. The two specimens tested had low volumetric swelling percentages of $0.15 \%$ and $0.82 \%$, with corresponding swelling pressures of $9.86 \mathrm{kPa}$ and $31.02 \mathrm{kPa}$. Figure 3.1 presents the stress-strain relations for the tests conducted. WFS specimens are labeled G1 and G3, and natural sand specimens are labeled R1. The tests showed that the WFS was more compressible than the natural sand. In addition, saturated specimens were generally more compressible than dry specimens. Javed and Lovell (1994) suggested the higher compressibility was due to the binders and additives which surround the sand particles. These binders are relatively weak in comparison to the bulky sand grains, and therefore are more likely to crush due to stress concentrations at the particle contacts. 


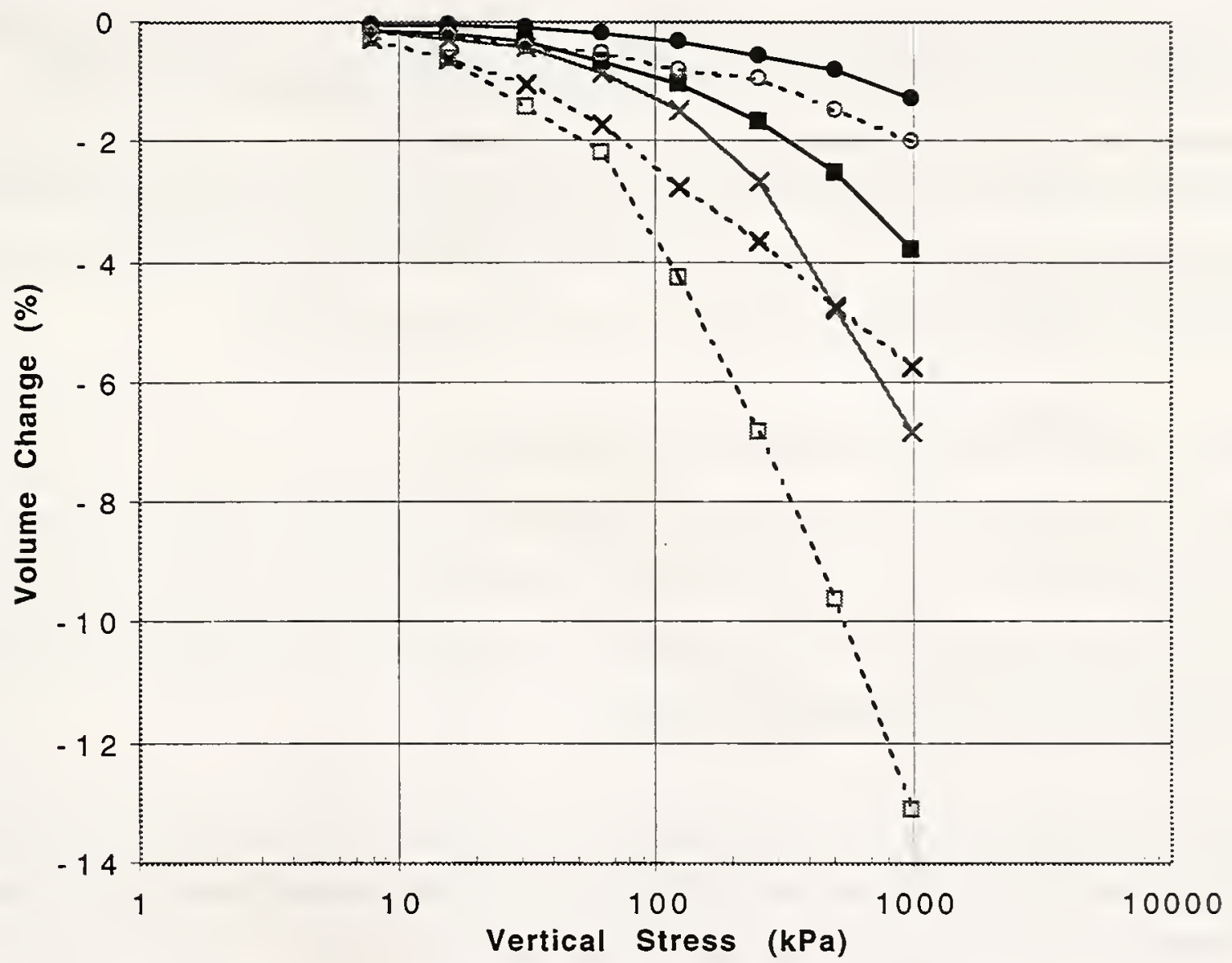

\begin{tabular}{|c|c|c|}
\hline$\rightarrow x-$ Dry G1 & $\longrightarrow$ Dry G3 & $\longrightarrow$ Dry R1 \\
\hline$---X--$ Sat. G1 & - - - - Sat. G3 & $--\infty-$ Sat. R1 \\
\hline
\end{tabular}

Figure 3.1. Compressibility Curves for Dry and Saturated WFS (after Javed and Lovell 1994). 


\subsubsection{Resilient Modulus of WFS}

Resilient modulus $\left(\mathrm{M}_{\mathrm{r}}\right)$ describes the response of a subgrade material to repeated dynamic loading. $M_{\tau}$ is the ratio of axial deviator stress $\left(\sigma_{d}\right)$ to the recoverable (or resilient) axial strain $\left(\varepsilon_{\mathrm{r}}\right)$. This ratio is dependent upon many parameters, including the axial load magnitude and waveform applied, confining pressure $\left(\sigma_{3}\right)$, degree of saturation, initial unit weight, and material gradation. Javed and Lovell (1994) ran resilient modulus tests in accordance with AASHTO T 274-82, with a few variations listed in their text. Specimen G1 was tested as a cohesionless material and Specimen G3 as a cohesive material. Table 3.1 presents the effects of water content, dry unit weight, relative compaction, and Califomia Bearing Ratio (CBR) on resilient modulus of WFS. Javed and Lovell (1994) concluded that values of $M_{工}$ for WFS are generally comparable or higher than most soils used for subgrade in Indiana.

\subsection{FIELD STUDIES OF WFS EMBANKMENTS}

Several states in the Midwest have reported using WFS in construction, including Michigan, Wisconsin, and Ohio. In most states, however, WFS reuse has been discontinued due to environmental concerns. For example, problems were encountered on a Michigan DOT project which showed a release of phenolic contaminants.

One WFS field study has been published which is particularly relevant to the current study (Lovejoy et al. 1996). The study was initiated in 1993 by the State of Wisconsin to evaluate WFS as a highway embankment material. The report discussed the pre-construction testing of foundry waste streams and two years of environmental testing in the field. The goals of the project were similar to the environmental research for the current project. Initially, solid waste streams from three Wisconsin foundries were tested for leachate characteristics. This testing included the use of the Toxicity Characteristic Leaching Procedure (TCLP) and the American Foundrymen's Society (AFS) test. It was determined that the waste streams from the three foundries were not hazardous. 
Table 3.1. Effect of Water Content, Dry Unit Weight, Relative Compaction, and CBR on Resilient Modulus of Green WFS (Javed and Lovell 1994).

\begin{tabular}{|c|c|c|c|c|c|c|c|c|}
\hline Test & $\begin{array}{c}\text { Water } \\
\text { Content }\end{array}$ & $\begin{array}{c}\text { Dry Unit } \\
\text { Weight }\end{array}$ & $\begin{array}{c}\text { Relative } \\
\text { Compaction }\end{array}$ & CBR & \multicolumn{3}{|c|}{ Resilient Modulus, $\mathrm{M}_{\mathrm{r}}(\mathrm{kPa})$} & \multirow{2}{*}{$\begin{array}{c}\sigma_{3} \\
(\%)\end{array}$} \\
& $\left(\mathrm{kN} / \mathrm{m}^{3}\right)$ & $(\%)$ & & & $\begin{array}{c}\sigma_{\mathrm{d}}= \\
20.7 \mathrm{kPa}\end{array}$ & $\begin{array}{c}\sigma_{\mathrm{d}}= \\
27.6 \mathrm{kPa}\end{array}$ & $\begin{array}{c}\sigma_{\mathrm{d}}= \\
62.0 \mathrm{kPa}\end{array}$ & \\
\hline G3A4 & 13.72 & 14.6 & 94.6 & 30.7 & 30642 & 27311 & 19746 & 20.7 \\
\hline G3A1 & 15.63 & 14.9 & 96.5 & 27.5 & 25936 & 23723 & 18450 & 20.7 \\
\hline G3A2 & 17.63 & 15.2 & 98.4 & 25.3 & 22548 & 21043 & 17322 & 20.7 \\
\hline G3A3 & 20.14 & 15.5 & 100.0 & 18.2 & 21297 & 18765 & 13133 & 20.7 \\
\hline G33 & 20.76 & 15.4 & 99.7 & 16.0 & 19779 & 15849 & 8488 & 6.9 \\
\hline G11 & 6.93 & 16.5 & 96.2 & 23.4 & 9825 & 8033 & 4554 & 6.9 \\
\hline G17 & 7.54 & 16.8 & 97.7 & 23.1 & 18999 & 16218 & 10383 & 6.9 \\
\hline G12 & 9.41 & 17.0 & 99.2 & 23.1 & 27291 & 23553 & 15550 & 6.9 \\
\hline G15 & 11.39 & 17.1 & 99.9 & 18.8 & 29128 & 25888 & 18565 & 6.9 \\
\hline G13 & 13.44 & 17.0 & 99.0 & 10.6 & 23325 & 20357 & 13872 & 6.9 \\
\hline
\end{tabular}


Two test sites chosen for the study were located in Waupaca, Wisconsin, and Appleton, Wisconsin. The Waupaca test site was completed in December 1987 using green WFS from the Waupaca Foundry. The Appleton test site was completed in May 1988 and used a mixture of green WFS and shell-molded WFS from the Brillion Foundry in Brillion, Wisconsin. Two embankments were constructed on each site, one with a typical construction soil and the other with WFS. Lysimeters were installed in each embankment to collect seepage water. In addition, groundwater monitoring wells were installed up- and down-gradient from the sites.

From a geotechnical perspective, the information in the report is sparse. The authors state that physical testing, performed by the Wisconsin DOT, confirmed that the WFS was acceptable for highway construction. However, no information was published regarding the test results. In addition, the authors state that the WFS and natural soil embankments were placed and compacted according to typical highway construction specifications. The authors have since learned of several other Wisconsin sites where WFS embankments were constructed. On these sites, the WFS was reportedly compacted to $95 \%$ of standard Proctor maximum dry unit weight and a friction angle of $30^{\circ}$ was used for design calculations. Again, no published data are available for the field or laboratory testing for these sites.

Lovejoy et al. (1996) reported that the lysimeters did not collect nearly as much effluent from within the WFS embankments as expected. By comparison, considerable effluent was collected from the lysimeters in the natural soil over the same period of time. Lovejoy et al. suggested that the low hydraulic conductivity was due to the compaction of the WFS. They reported that the material was compacted in 152 to $305 \mathrm{~mm}$ loose lifts, near optimum moisture content. They also stated that further compaction occurred during construction due to the trafficking of heavy equipment. Hydraulic conductivity tests performed at the University of Wisconsin-Madison confirmed the low field hydraulic conductivities, although a report on his work has not been published.

The low hydraulic conductivity of WFS is a very important observation from a geotechnical standpoint. It indicates that the material is not freely draining and that excess pore pressures 
generated in a WFS embankment would not dissipate quickly. This could be an important consideration for using WFS materials behind retaining walls, where lateral earth pressure is a primary concern.

Lovejoy et al. (1996) concluded that there were several parameters which exceeded the Drinking Water Standards at least once during the $1.5 \mathrm{yr}$. collection period. For the WFS lysimeters, these parameters included $\mathrm{pH}$, chloride, and iron. For the natural soils, these parameters included: chromium, cadmium, sulfate, selenium, total dissolved solids, zinc, and fluoride. The groundwater monitoring wells did not show any impacts that can be attributed to either the WFS or natural soil embankments. However, the authors noted that the sampling time period may not have been sufficient to flush the WFS due to its low hydraulic conductivity. 



\section{CHAPTER 4: LABORATORY TESTING RESULTS}

\subsection{MATERIAL COLLECTION}

Laboratory tests were performed on "fresh" and "weathered" WFS from the Auburn Foundry monofill. Five buckets of WFS were collected on March 3, 1995; two buckets of fresh WFS that was placed the same day, and three buckets of weathered WFS that had been at the surface of the monofill for several months. These WFS samples are designated "Sample \#1". Two additional samples of weathered WFS, designated "Sample \#2" and "Sample \#3", were collected from the same monofill on May 23, 1996. These samples were used for grain size analysis, Method B Proctor testing, and hydraulic conductivity testing. Table 4.1 presents an overview of the results that were obtained from the laboratory testing program.

\subsection{GRAIN SIZE DISTRIBUTION}

Figure 4.1 presents the results of sieve and hydrometer tests for fresh and weathered WFS. The grain size distribution for fresh WFS consists of $60 \%$ sand and $40 \%$ fines. Grain sizes for the weathered WFS are coarser, with fines content ranging from $10 \%$ to $22 \%$. This is likely due to the washing of fine particles out of WFS during weathering. One hydrometer test performed on the weathered WFS yielded a clay content $(\leq 0.005 \mathrm{~mm})$ of $9 \%$. The grain size distributions for the weathered WFS samples vary by as much as $30 \%$ at a given grain size for particles larger than $0.2 \mathrm{~mm}$. This variability reflects differences within the stockpile for weathered WFS.

Javed and Lovell (1994) reported grain size distributions for seven Indiana green sand WFS samples. Figure 4.2 presents those data along with the test results from Samples \#1 and \#2 and tests performed by the INDOT Materials Testing Laboratory for this project. Sample $\# 2$ has a higher percentage of coarse particles than most of the other samples tested. This may 
Table 4.1. Geotechnical Laboratory Test Results for Auburn WFS.

\begin{tabular}{|c|c|c|c|c|}
\hline \multicolumn{2}{|l|}{ Test } & Symbol & $\begin{array}{l}\text { Weathered } \\
\text { WFS }\end{array}$ & $\begin{array}{l}\text { Fresh } \\
\text { WFS }\end{array}$ \\
\hline \multicolumn{2}{|c|}{ Initial Water Content (ASTM D 2216) } & $w_{n}$ & $24.5 \%$ & $16.6 \%$ \\
\hline \multicolumn{2}{|l|}{ Liquid Limit (ASTM D 4318) } & $\mathrm{w}_{\mathrm{L}}$ & $30.7 \%$ & -- \\
\hline \multicolumn{2}{|l|}{ Plastic Limit (ASTM D 4318) } & $\mathrm{w}_{\mathrm{P}}$ & $24.7 \%$ & -- \\
\hline \multicolumn{2}{|c|}{ Specific Gravity of Solids (ASTM D 854) } & $\mathrm{G}_{\mathrm{s}}$ & 2.53 & 2.46 \\
\hline \multicolumn{2}{|c|}{ Percentage of Coarse Particles (ASTM D 422) } & R200 & $78-90 \%$ & $60 \%$ \\
\hline \multicolumn{2}{|c|}{$\begin{array}{l}\text { Percentage of Fines (Passing \# } 200 \text { Sieve) } \\
\text { (ASTM D 422) }\end{array}$} & $\mathrm{P} 200$ & $10-22 \%$ & $40 \%$ \\
\hline \multicolumn{2}{|c|}{$\begin{array}{l}\text { Percentage of Clay Size Particles }(<0.005 \mathrm{~mm} \text { ) } \\
\text { (ASTM D 422) }\end{array}$} & & $9 \%$ & -- \\
\hline \multirow{2}{*}{$\begin{array}{l}\text { Standard Proctor } \\
\text { Compaction } \\
\text { Method A (ASTM D 698) }\end{array}$} & $\begin{array}{l}\text { Optimum } \\
\text { Moisture Content }\end{array}$ & OMC & $27.1 \%$ & $23.1 \%$ \\
\hline & $\begin{array}{l}\text { Maximum } \\
\text { Dry Unit Weight }\end{array}$ & $\gamma_{\mathrm{d}, \max }$ & $\begin{array}{c}14.0 \\
\mathrm{kN} / \mathrm{m}^{3}\end{array}$ & $13.4 \mathrm{kN} / \mathrm{m}^{3}$ \\
\hline \multirow{2}{*}{$\begin{array}{l}\text { Standard Proctor } \\
\text { Compaction } \\
\text { Method B (ASTM D 698) }\end{array}$} & $\begin{array}{l}\text { Optimum } \\
\text { Moisture Content }\end{array}$ & OMC & $15.5 \%$ & -- \\
\hline & $\begin{array}{l}\text { Maximum } \\
\text { Dry Unit Weight }\end{array}$ & $\gamma_{\text {d,max }}$ & $\begin{array}{c}16.8 \\
\mathrm{kN} / \mathrm{m}^{3}\end{array}$ & -- \\
\hline \multirow{2}{*}{$\begin{array}{l}\text { Modified Proctor } \\
\text { Compaction } \\
\text { Method B (ASTM D 1557) }\end{array}$} & $\begin{array}{l}\text { Optimum } \\
\text { Moisture Content }\end{array}$ & OMC & $12.8 \%$ & -- \\
\hline & $\begin{array}{l}\text { Maximum } \\
\text { Dry Unit Weight }\end{array}$ & $\gamma_{d, \max }$ & $\begin{array}{c}18.2 \\
\mathrm{kN} / \mathrm{m}^{3}\end{array}$ & -- \\
\hline
\end{tabular}


Table 4.1. (cont.)

\begin{tabular}{|c|c|c|c|c|}
\hline Test & & Symbol & $\begin{array}{c}\text { Weathered } \\
\text { WFS }\end{array}$ & $\begin{array}{l}\text { Fresh } \\
\text { WFS }\end{array}$ \\
\hline \multirow{2}{*}{$\begin{array}{l}\text { Vibratory Compaction } \\
\text { (ASTM D 4253) }\end{array}$} & $\begin{array}{l}\text { Optimum } \\
\text { Moisture Content }\end{array}$ & OMC & $28.8 \%$ & - \\
\hline & $\begin{array}{l}\text { Maximum } \\
\text { Dry Unit weight }\end{array}$ & $\gamma_{d, \max }$ & $13.3 \mathrm{kN} / \mathrm{m}^{3}$ & - \\
\hline \multirow{4}{*}{$\begin{array}{l}\text { Direct Shear } \\
\text { (ASTM D 3080) }\end{array}$} & $\begin{array}{l}\text { Cohesion } \\
\text { Intercept, Loose } \\
\text { Specimen }\end{array}$ & $c^{\prime}$ & $6.9 \mathrm{kN} / \mathrm{m}^{2}$ & $13.8 \mathrm{kN} / \mathrm{m}^{3}$ \\
\hline & $\begin{array}{l}\text { Cohesion } \\
\text { Intercept, Dense } \\
\text { Specimen }\end{array}$ & $c^{\prime}$ & $13.1 \mathrm{kN} / \mathrm{m}^{3}$ & $15.2 \mathrm{kN} / \mathrm{m}^{3}$ \\
\hline & $\begin{array}{l}\text { Internal Friction } \\
\text { Angle, Loose } \\
\text { Specimen }\end{array}$ & $\phi^{\prime}$ & $35^{\circ}$ & $33^{\circ}$ \\
\hline & $\begin{array}{l}\text { Internal Friction } \\
\text { Angle, Dense } \\
\text { Specimen }\end{array}$ & $\phi^{\prime}$ & $38^{\circ}$ & $39^{\circ}$ \\
\hline \multirow{2}{*}{$\begin{array}{l}\text { California Bearing Ratio } \\
\text { (5 mm penetration) } \\
\text { (ASTM D 1883) }\end{array}$} & Soaked Specimen & CBR & 16.8 & 6.2 \\
\hline & $\begin{array}{l}\text { Unsoaked } \\
\text { Specimen }\end{array}$ & CBR & 17.9 & 14.1 \\
\hline \multicolumn{2}{|l|}{ CBR Swell (\% swelling) } & & $0 \%$ & $0.9 \%$ \\
\hline \multirow[b]{2}{*}{$\begin{array}{l}\text { Hydraulic Conductivity } \\
\text { (ASTM D1883, D 5084) }\end{array}$} & $\begin{array}{l}\text { Falling Head, } \\
\text { Fixed Wall } \\
\end{array}$ & $\mathrm{k}$ & $\begin{array}{c}1.4 \times 10^{-6} \\
\mathrm{~m} / \mathrm{s}\end{array}$ & $\begin{array}{c}1.8 \times 10^{-7} \\
\mathrm{~m} / \mathrm{s}\end{array}$ \\
\hline & $\begin{array}{l}\text { Falling Headwater } \\
\text { /Rising Tailwater } \\
\text { Flexible Wall }\end{array}$ & $\mathrm{k}$ & $\begin{array}{l}\text { Std. Proctor } \\
\text { wet of OMC } \\
\begin{array}{c}1.2 \times 10^{-8} \\
\mathrm{~m} / \mathrm{s}\end{array}\end{array}$ & -- \\
\hline
\end{tabular}




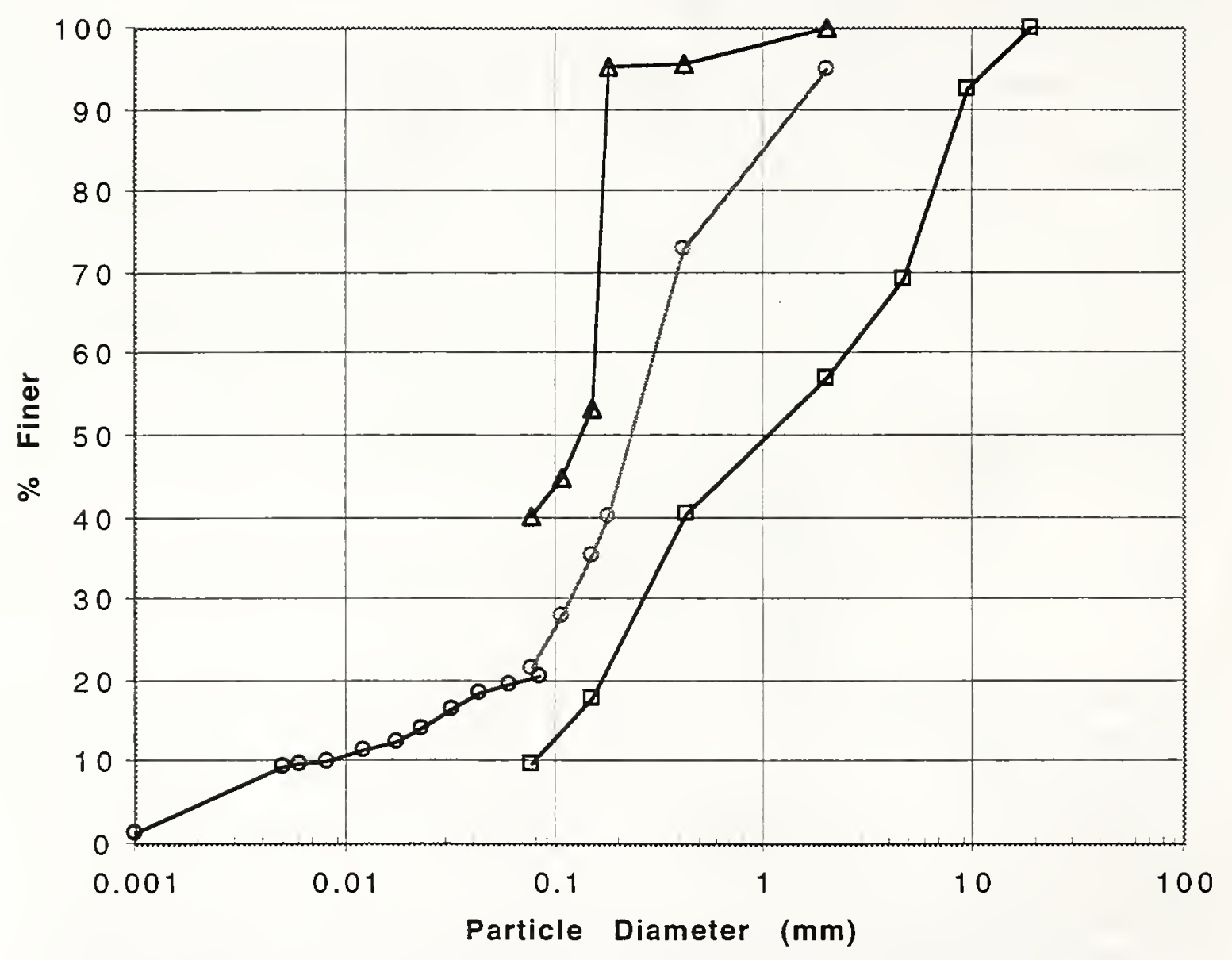

$\triangle$ Fresh WFS $\quad-0$-Weathered WFS Sample \#1

-Weathered WFS Sample \#2

Figure 4.1. Grain Size Distributions for Weathered and Fresh WFS. 


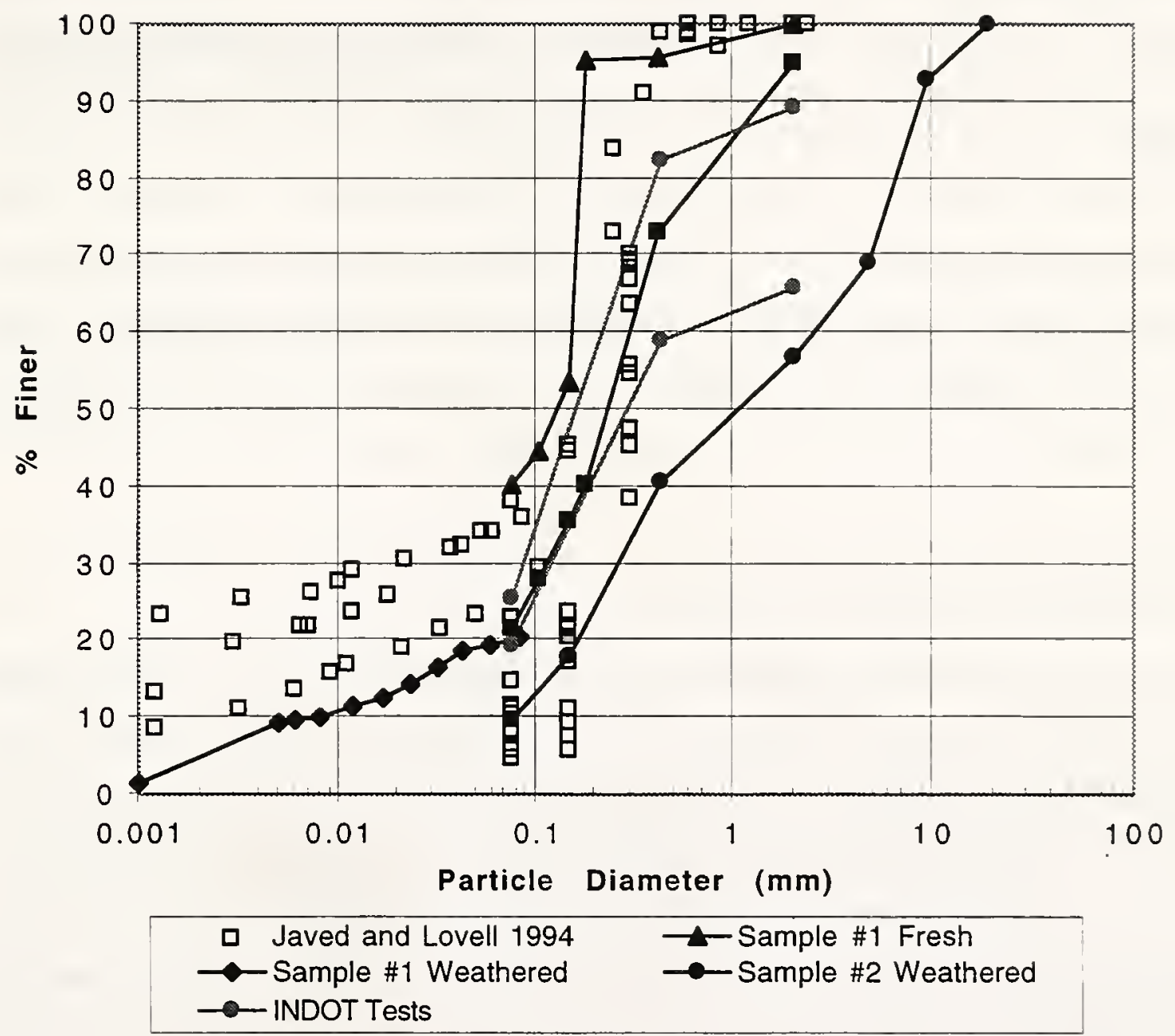

Figure 4.2. WFS Grain Size Distributions. 
explain the higher dry unit weights obtained during compaction testing of Sample \#2 (see Section 4.5). Overall, Figure 4.2 indicates that there may be a large variation in the grain size distribution for green sand WFS samples.

The characteristically lower fines content for weathered WFS may vary with depth in the monofill. This would be an important consideration for construction operations because the WFS may have significantly different grains size distributions for varying depths within the monofill.

The grain size distribution of WFS is used for soil classification and to assess the frost susceptibility of the material. The fraction of silts for weathered WFS is small, leading to the conclusion that weathered WFS is probably not highly susceptible to frost action. The grain size distribution also mandates the appropriate compaction testing method (see Section 4.5).

\subsection{SPECIFIC GRAVITY OF SOLIDS}

The specific gravity of solids $\left(G_{s}\right)$ for weathered WFS Sample \#1 was 2.53. The fresh WFS has a $G_{s}$ value of 2.46. For comparison, Javed and Lovell (1994) reported specific gravity values for seven green sand foundry samples ranging from 2.35 to 2.58 , with an average value of 2.49. The WFS samples tested by Javed and Lovell were not specified as "weathered" or "fresh". As per ASTM procedures, the materials were passed through the \#4 sieve prior to testing. This may produce different $G_{s}$ values as compared to samples with a full range of particle sizes.

\subsection{ATTERBERG LIMITS}

Values of liquid limit $\left(\mathrm{W}_{\mathrm{L}}\right)$ and plastic limit $\left(\mathrm{W}_{\mathrm{P}}\right)$ for weathered WFS are 30.7 and 24.7, respectively. The plasticity index $(\mathrm{PI})$ is $\mathrm{w}_{\mathrm{L}}-\mathrm{w}_{\mathrm{P}}=6.0$. For comparison, Javed and Lovell (1994) measured an average $w_{L}$ of 34.6 , with a range of 29.1 to 44.3. The average $w_{P}$ was 9.75, with a range of 8.0 to 11.8 . 
Using grain size distribution and Atterberg limits data, the weathered green WFS is classified as a SM (silty sand) in the USCS system. In the AASHTO system, most of the samples tested would be classified as A-2-4, with a general subgrade rating of good to excellent.

\subsection{PROCTOR COMPACTION}

Weathered WFS Sample \#2 was tested according to the standard Proctor Method B (ASTM D 698 ) and modified Proctor Method B (ASTM D 1557) procedures. The Method B procedure is specified for samples with more than $20 \%$ material (by weight) retained on the No. 4 (4.75 $\mathrm{mm}$ ) sieve and $20 \%$ or less material (by weight) retained on the $3 / 8 \mathrm{in}$. $(9.5 \mathrm{~mm}$ ) sieve. The weathered WFS Sample \#l was also tested by the standard Proctor method A (ASTM D 698) procedure.

The compaction curves are presented in Figure 4.3. The zero air voids (ZAV) curve is shown for $\mathrm{G}_{\mathrm{s}}=2.53$. The standard Proctor data for WFS Sample \#2 indicate an optimum moisture content (OMC) of $15.5 \%$ and maximum dry unit weight $\left(\gamma_{d \text { max }}\right)$ of $16.8 \mathrm{kN} / \mathrm{m}^{3}(107 \mathrm{pcf})$. The modified Proctor data for WFS Sample \#2 give OMC $=12.8 \%$ and $\gamma_{\mathrm{d}, \max }=17.8 \mathrm{kN} / \mathrm{m}^{3}(113$ pcf). The results of the Method A standard Proctor test on Sample \#1 give OMC $=27.1 \%$ and $\gamma_{d, \max }$ of $14.0 \mathrm{kN} / \mathrm{m}^{3}$ (89.1 pcf). From this figure, a comparison of Method A and Method B tests shows significant differences.

Figure 4.4 presents two standard Proctor compaction tests performed by Javed and Lovell (1994) along with data from Figure 4.3. In addition, eight compaction tests performed by the INDOT materials laboratory have been included. The INDOT tests were performed according to AASHTO T-99 such that the material was passed through the $3 / 8$ in. sieve, which is consistent with the ASTM Method B procedure. The INDOT data are in general agreement with Method B tests conducted by the authors. Figure 4.5 presents the compaction curve for a standard Proctor test (Method A) of fresh WFS. The OMC is $23.1 \%$ and $\gamma_{\mathrm{d} \text {.max }}=13.4 \mathrm{kN} / \mathrm{m}^{3}$ 


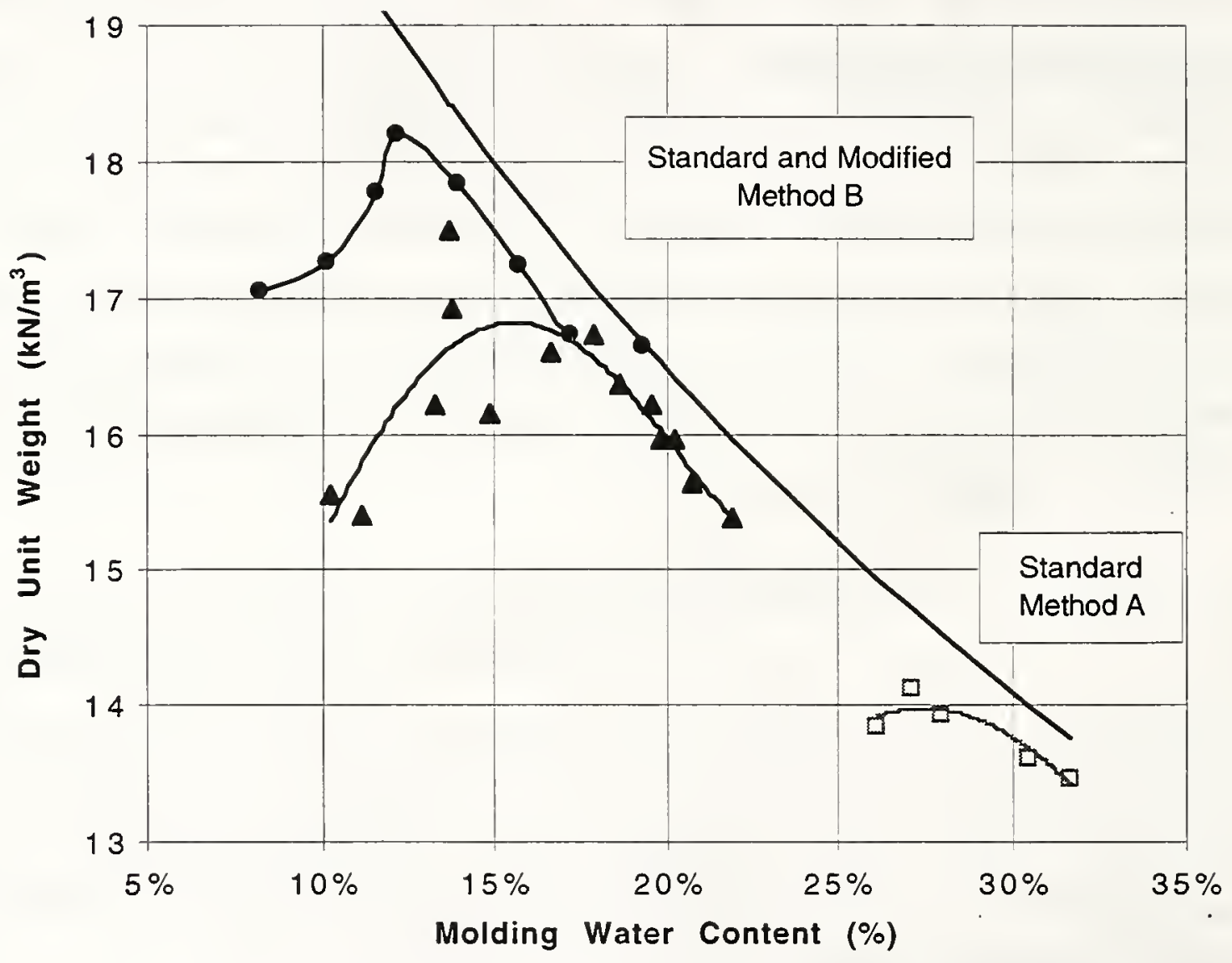

A Standard Proctor Sample \#2 $\rightarrow$ Modified Test Sample \#2 ZAV Gs $=2.53$ 口 Weathered WFS Sample \#1

Figure 4.3. Proctor Compaction Data for Weathered WFS. 


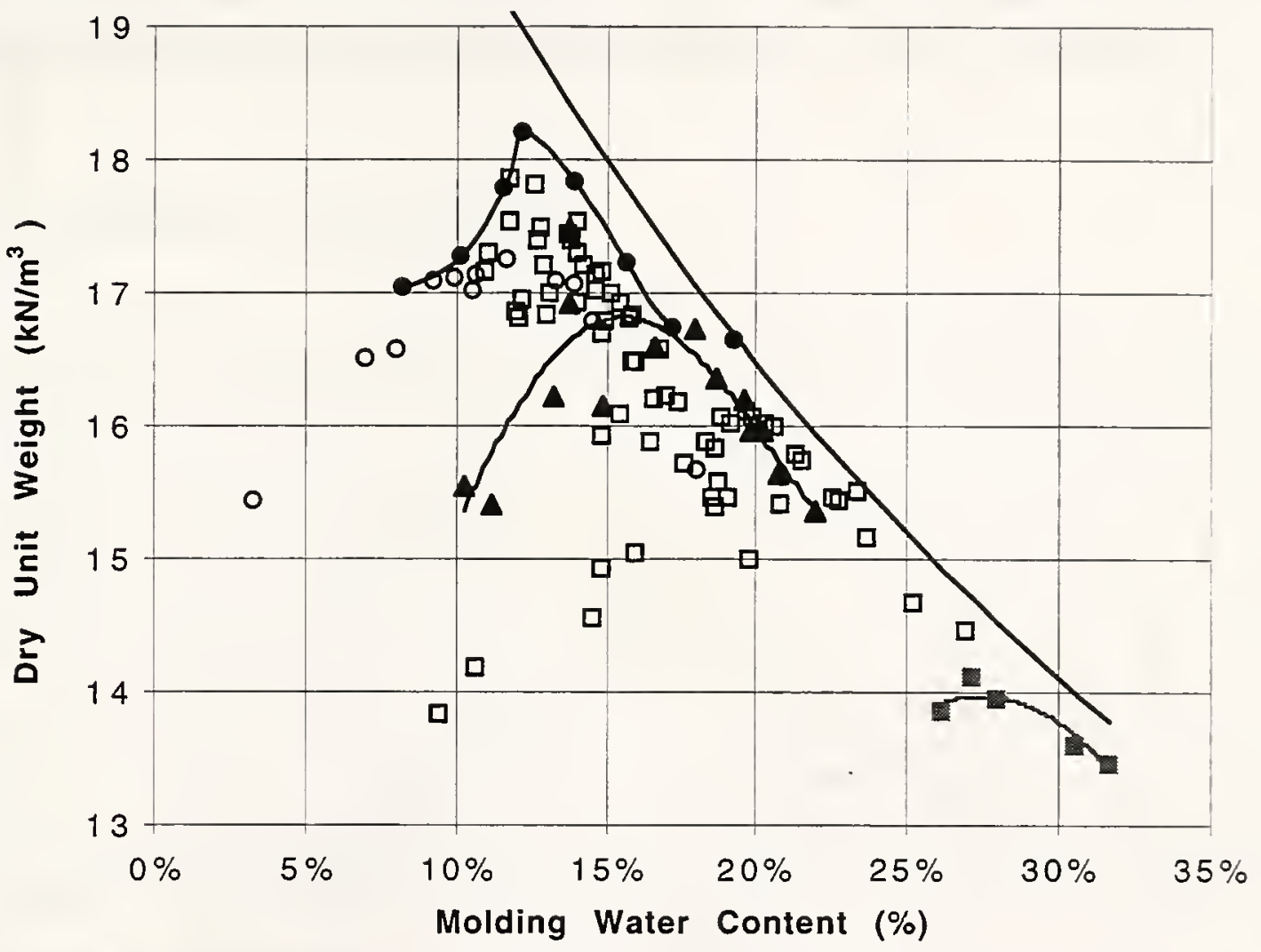

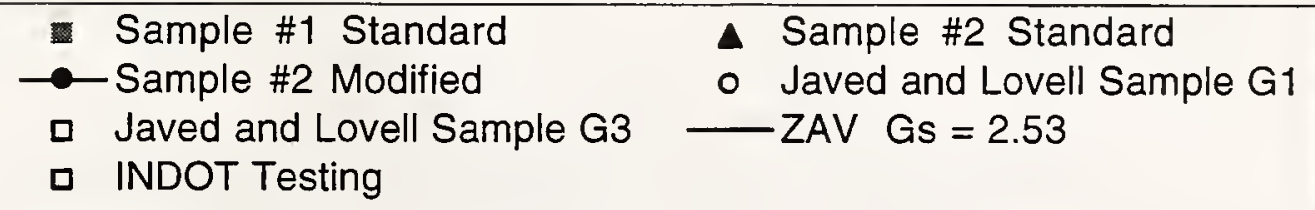

Figure 4.4. Proctor Compaction Curves for Weathered WFS. 


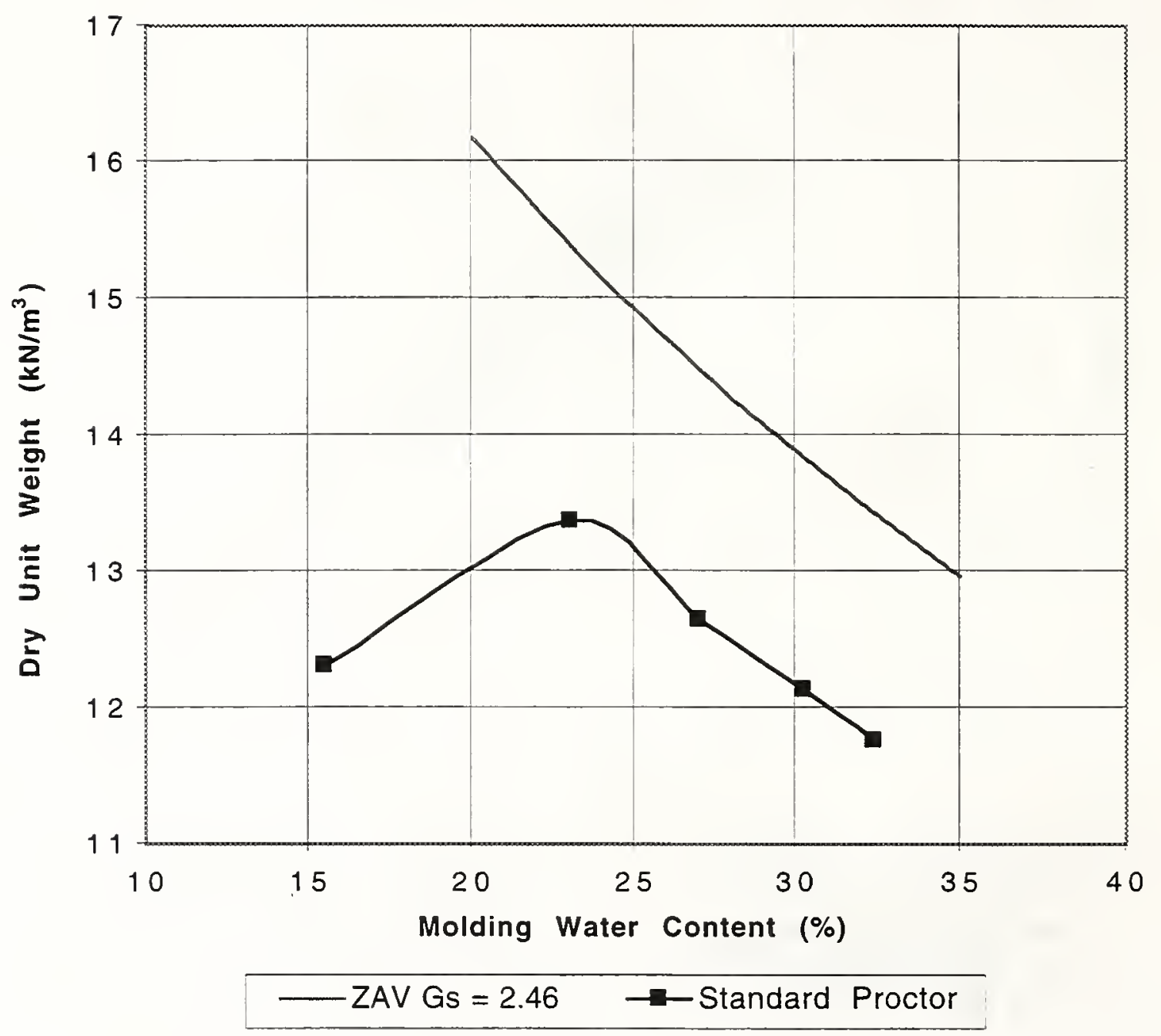

Figure 4.5. Method A Standard Proctor Curve for Fresh WFS (Sample \#1). 
(85.1 pcf). The OMC and maximum dry unit weight are both less than those of the weathered WFS.

Figures 4.3 through 4.5 show that there is a wide range of OMC and $\gamma_{d, \max }$ for Auburn WFS. The Proctor Method B procedure results in a higher dry unit weight than Method A. This is probably due to the larger particles (steel slag) in the Method B Proctor specimens.

\subsection{VIBRATORY COMPACTION}

The maximum dry unit weight for the vibratory compaction test is determined by using a standard Proctor mold on a vibratory table with a $13.8 \mathrm{kPa}$ surcharge. A specimen of weathered WFS Sample \#1 was tested using the vibratory table in the Purdue Geotechnical Laboratory with an amplitude of $0.0068 \mathrm{in}$. and a frequency of $60 \mathrm{~Hz}$. Figure 4.6 presents the measured compaction curve. The OMC and maximum dry unit weight are $28.8 \%$ and 13.3 $\mathrm{kN} / \mathrm{m}^{3}$ (84.9 pcf), respectively. For comparison, Javed and Lovell (1994) used the same procedure on two dry WFS samples. The maximum unit weights were $16.2 \mathrm{kN} / \mathrm{m}^{3}(103.4$ pcf) and $13.6 \mathrm{kN} / \mathrm{m}^{3}(86.8 \mathrm{pcf})$, which are larger than the Sample \#1 test results. A comparison of the Proctor compaction curves and the vibratory compaction curves suggests that WFS will be compacted to a higher unit weight by a rubber-tired roller in the field, as compared to a vibratory roller.

\subsection{CALIFORNIA BEARING RATIO}

The California bearing ratio (CBR) test measures the resistance of compacted soil to a piston load applied at a constant displacement rate. The test is performed on a soil which is compacted at OMC. One specimen is tested immediately after compaction, while a second specimen is submerged (soaked) for 4 days prior to testing. CBR is often used to evaluate base course or subbase materials for flexible pavement construction. The CBR value is defined as the stress (as a percent) required to penetrate the specimen to a specified depth (2.5 mm and $5.0 \mathrm{~mm}$ ) divided by the stress required to penetrate standard crushed rock to the same depth. 


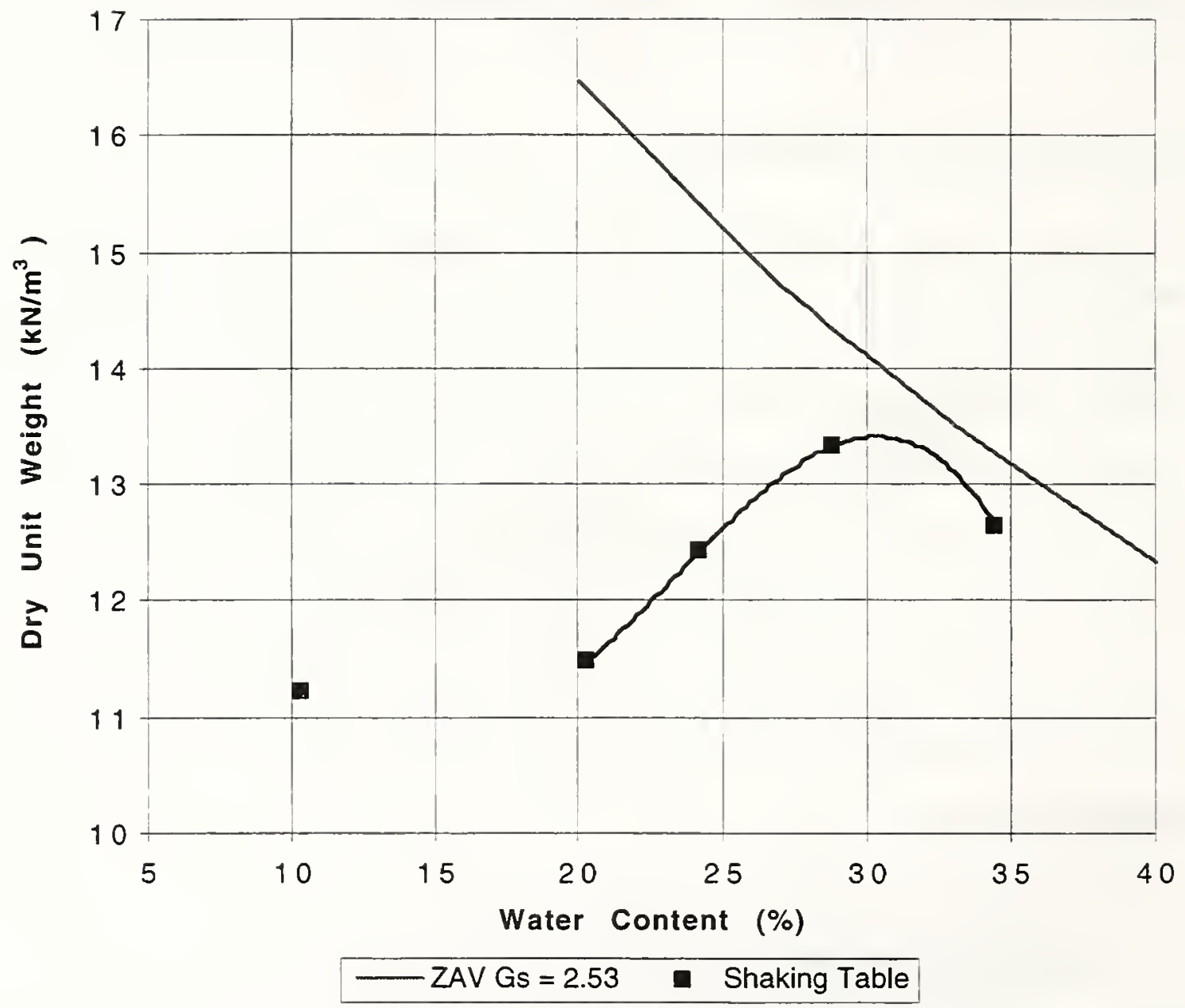

Figure 4.6. Vibratory Compaction Curve for WFS (Sample \#1). 
The following values of CBR are recommended for classification of potential road subbase and base soils (Bowles 1992):

$\begin{array}{cc}\text { CBR } & \text { Material Rating } \\ 0-7 & \text { Poor } \\ 7-20 & \text { Fair } \\ 20-50 & \text { Good } \\ >50 & \text { Excellent }\end{array}$

The CBR soak test is used to evaluate road subbase or base soils in the fully hydrated condition. The specimens are compacted in the same CBR mold, a surcharge is applied to the top of the specimen, and swelling is recorded over the 4 day period. The soak test gives an indication of the potential for swelling of the road base soils after compaction. The CBR value after soaking is often considered the worst-case condition for a particular soil.

Figure 4.7 shows the stress-penetration curves for CBR tests of soaked and unsoaked weathered WFS specimens, both from Sample \#1. Figure 4.8 gives the corresponding curves for soaked and unsoaked fresh WFS. Figure 4.9 presents the results of the swelling test for fresh WFS. The swelling data are plotted as change in height divided by initial height before soaking $\left(\Delta \mathrm{H} / \mathrm{H}_{\mathrm{o}}\right)$ versus time. After 4 days of soaking, the specimen swelled $0.9 \%$. The weathered WFS Sample \#1 did not swell during four days of soaking. The results of CBR tests for both weathered and fresh WFS specimens are presented in Table 4.2 along with data obtained by Javed and Lovell (1994). The testing results are in good agreement.

The CBR values are 18 and 17 for unsoaked and soaked weathered WFS, indicating that this material is a "fair" subbase material. The fresh WFS has lower CBR values, which are likely due to the higher percentage of fines and limited swelling behavior of fresh WFS. The low swelling potential of the WFS specimens tested advantageous for use in road construction. 


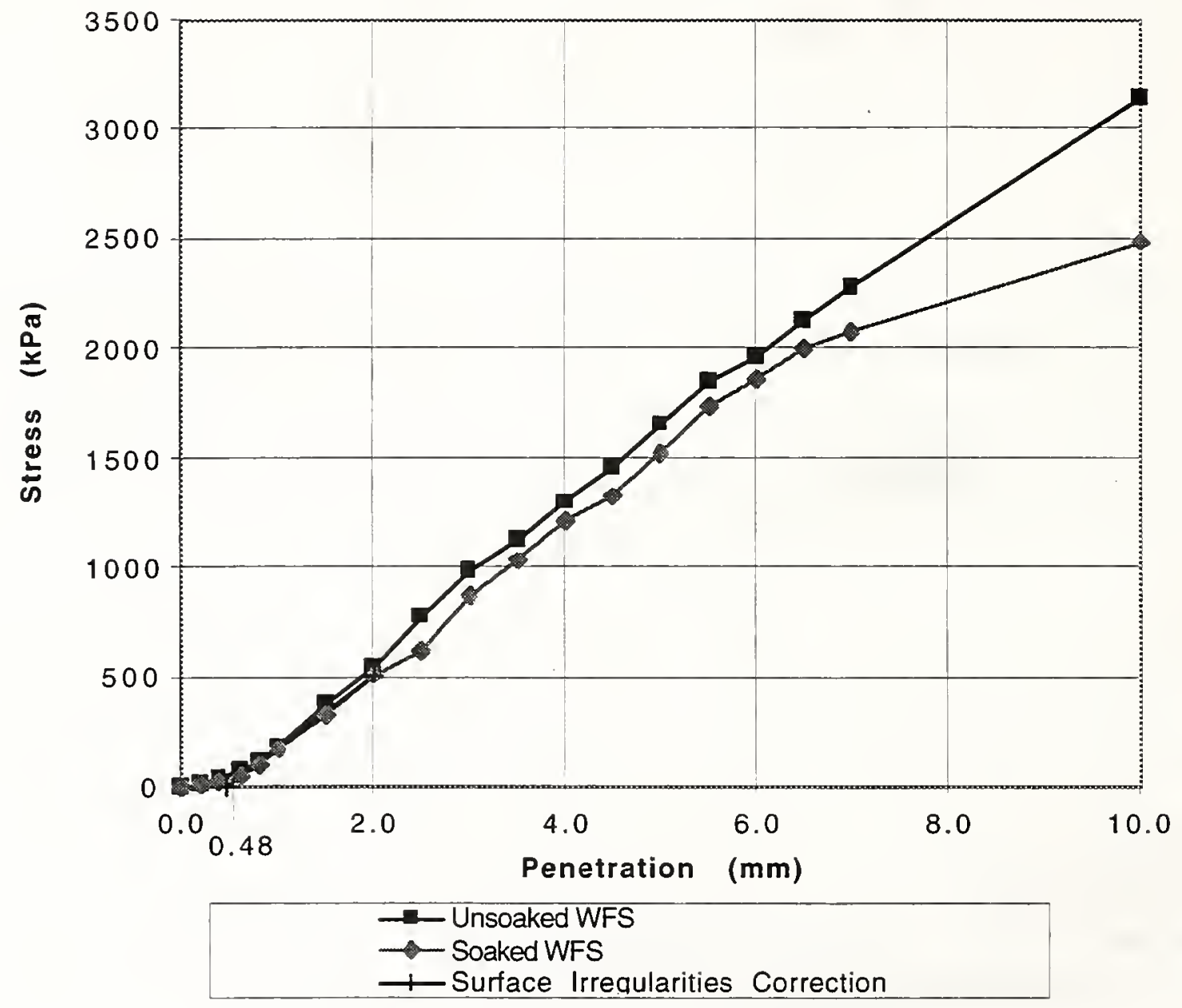

Figure 4.7. CBR Test Results for Unsoaked and Soaked Weathered WFS (Sample \#1). 


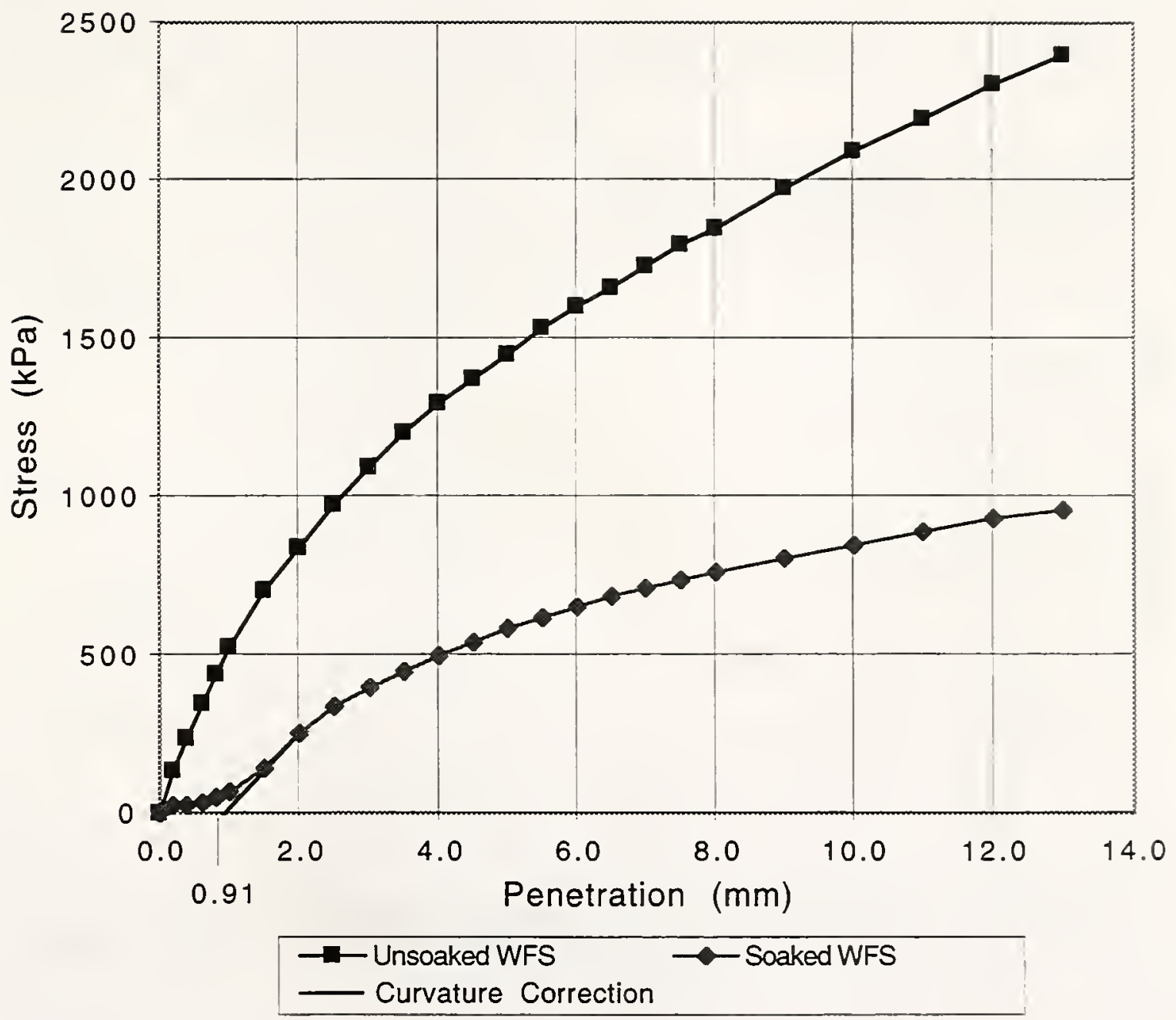

Figure 4.8. CBR Test Results for Unsoaked and Soaked Fresh WFS (Sample \#1). 


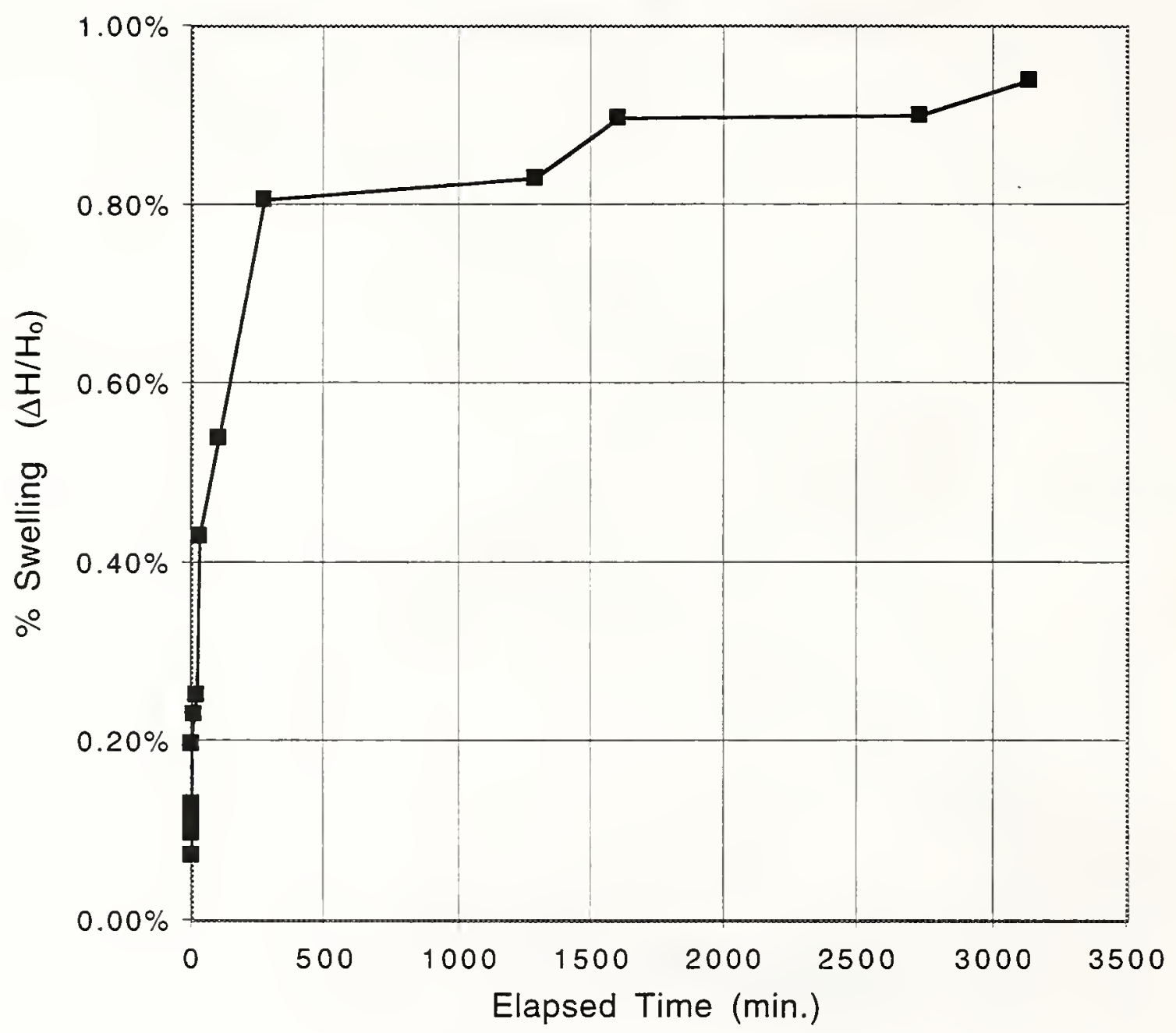

Figure 4.9. CBR Swell Test Results for Fresh WFS (Sample \#1). 
Table 4.2. CBR Test Results for WFS.

\begin{tabular}{|c|c|c|c|c|c|}
\hline & CBR Test & $\begin{array}{l}\text { Weathered } \\
\text { WFS \#1 }\end{array}$ & $\begin{array}{c}\text { Fresh } \\
\text { WFS \#1 }\end{array}$ & $\begin{array}{r}\text { Javed ar } \\
\qquad(19\end{array}$ & $\begin{array}{l}\text { Lovell } \\
\text { 4) }\end{array}$ \\
\hline \multirow[t]{3}{*}{$\begin{array}{l}\text { Unsoaked } \\
\text { Specimens }\end{array}$} & $\begin{array}{l}\text { Molding water } \\
\text { content }\end{array}$ & $27 \%$ & $20 \%$ & $12 \%$ & $21 \%$ \\
\hline & $\mathrm{CBR}$ at $2.5 \mathrm{~mm}$ & 14.2 & 14.1 & 12.1 & -- \\
\hline & $\mathrm{CBR}$ at $5.0 \mathrm{~mm}$ & 17.9 & 14.1 & 16.9 & 17.5 \\
\hline \multirow{4}{*}{$\begin{array}{l}\text { Soaked } \\
\text { Specimens } \\
\text { (4 days of } \\
\text { soaking) }\end{array}$} & After soaking w $\%$ & $28 \%$ & $27 \%$ & -- & -- \\
\hline & $\%$ swell & $0.0 \%$ & $0.9 \%$ & $0.03 \%$ & $0.0 \%$ \\
\hline & $\begin{array}{c}\text { CBR at } 2.5 \mathrm{~mm} \\
\text { (\% strength decrease } \\
\text { due to soaking) }\end{array}$ & $\begin{array}{c}12.7 \\
(13 \%)\end{array}$ & $\begin{array}{c}6.4 \\
(55 \%)\end{array}$ & 14.3 & 9.4 \\
\hline & $\begin{array}{c}\text { CBR at } 5.0 \mathrm{~mm} \\
\text { (\% strength decrease } \\
\text { due to soaking) }\end{array}$ & $\begin{array}{l}16.8 \\
(6 \%)\end{array}$ & $\begin{array}{c}6.2 \\
(56 \%)\end{array}$ & 18.0 & 11.8 \\
\hline
\end{tabular}




\subsection{HYDRAULIC CONDUCTIVITY}

Table 4.3 presents a summary of the hydraulic conductivity test results. The first test was performed using a fixed wall permeameter. The specimen was compacted dry using a Harvard miniature compaction device. The hydraulic conductivity values for weathered and fresh WFS are $1.35 \times 10^{-6} \mathrm{~m} / \mathrm{s}$ and $1.84 \times 10^{-7} \mathrm{~m} / \mathrm{s}$, respectively.

A second set of tests was performed on $10.2 \mathrm{~cm}$ diameter weathered WFS specimens using a flexible wall permeameter. These specimens were compacted by the Method B standard and modified Proctor methods. The standard Proctor specimen was compacted wet of OMC and the modified Proctor specimen was compacted at dry of OMC. Both specimens were saturated at $68.9 \mathrm{kPa}$ backpressure for $24 \mathrm{hr}$. The standard Proctor specimen gave a hydraulic conductivity $(\mathrm{k})$ of $1.2 \times 10^{-8} \mathrm{~m} / \mathrm{s}$ and the modified Proctor specimen gave $\mathrm{k}=7.1 \times 10^{-7} \mathrm{~m} / \mathrm{s}$. Consistent with the behavior for natural clay soils, WFS specimens compacted wet of OMC have significantly lower hydraulic conductivities. The standard Proctor value is almost two orders of magnitude less than the fixed wall value, which may be due to sidewall leakage in fixed wall permeameter.

Javed and Lovell (1994) performed flexible wall hydraulic conductivity tests using the falling head method. Their specimens were compacted at standard Proctor energy. For two WFS specimens, hydraulic conductivity values were $2.8 \times 10^{-7} \mathrm{~m} / \mathrm{s}$ and $2.6 \times 10^{-8} \mathrm{~m} / \mathrm{s}$. The lower hydraulic conductivity specimen had a fines content of $36 \%$, compared to $5 \%$ for the specimen with higher hydraulic conductivity. For clean fine sands, a typical range of hydraulic conductivity is $5 \times 10^{-4}$ to $5 \times 10^{-6} \mathrm{~m} / \mathrm{s}$. The WFS specimens had a significantly lower $\mathrm{k}$ values, presumably due to the fines content of the WFS. 
Table 4.3. Hydraulic Conductivity of WFS.

\begin{tabular}{|c|c|c|c|c|}
\hline Sample & Test Method & $\begin{array}{c}\text { Compaction } \\
\text { Method }\end{array}$ & $\begin{array}{c}\text { Molding } \\
\text { w\% }\end{array}$ & $\begin{array}{c}\mathrm{k} \\
(\mathrm{m} / \mathrm{s})\end{array}$ \\
\hline $\begin{array}{l}\text { Fresh } \\
\text { WFS }\end{array}$ & Fixed Wall & Harvard Miniature & dry & $1.8 \times 10^{-7}$ \\
\hline \multirow{5}{*}{$\begin{array}{c}\text { Weathered } \\
\text { WFS }\end{array}$} & Fixed Wall & Harvard Miniature & dry & $1.4 \times 10^{-6}$ \\
\hline & Flexible Wall & Modified Proctor & $\begin{array}{c}11.3 \% \\
(\mathrm{OMC}=12 \%)\end{array}$ & $7.1 \times 10^{-7}$ \\
\hline & Flexible Wall & Standard Proctor & $\begin{array}{c}18.9 \% \\
(\mathrm{OMC}=15.5 \%)\end{array}$ & $1.2 \times 10^{-8}$ \\
\hline & $\begin{array}{c}\text { Flexible Wall } \\
\text { (Javed and Lovell } \\
\text { 1994) }\end{array}$ & Standard Proctor & near OMC & $\begin{array}{c}2.8 \times 10^{-7} \\
\text { (low \% fines) }\end{array}$ \\
\hline & $\begin{array}{c}\text { Flexible Wall } \\
\text { (Javed and Lovell } \\
\text { 1994) }\end{array}$ & Standard Proctor & near OMC & $\begin{array}{c}2.6 \times 10^{-8} \\
\text { (high \% fines) }\end{array}$ \\
\hline
\end{tabular}




\subsection{SHEAR STRENGTH}

Figure 4.10 shows the shear stress versus horizontal displacement curves for loose weathered WFS (Sample \#1) at the following normal stresses: $14.2 \mathrm{kPa}, 35.5 \mathrm{kPa}, 71.0 \mathrm{kPa}$, and 141.9 $\mathrm{kPa}$. Figure 4.11 shows the shear stress-horizontal displacement curves for dense weathered WFS (Sample \# 1) at the same normal stresses. Corresponding results for fresh WFS are shown in Figures 4.12 and Figure 4.13. In general, the dense specimens show a tendency for more strain-softening than the loose specimens. Failure envelopes for the loose and dense WFS specimens are shown in Figures 4.14 and Figure 4.15, respectively. Table 4.4 presents a summary of the measured shear strength parameters along with results obtained by Javed and Lovell (1994). In addition, failure envelopes for their testing are plotted on Figures 4.14 and 4.15. The results from the two studies show good agreement. 


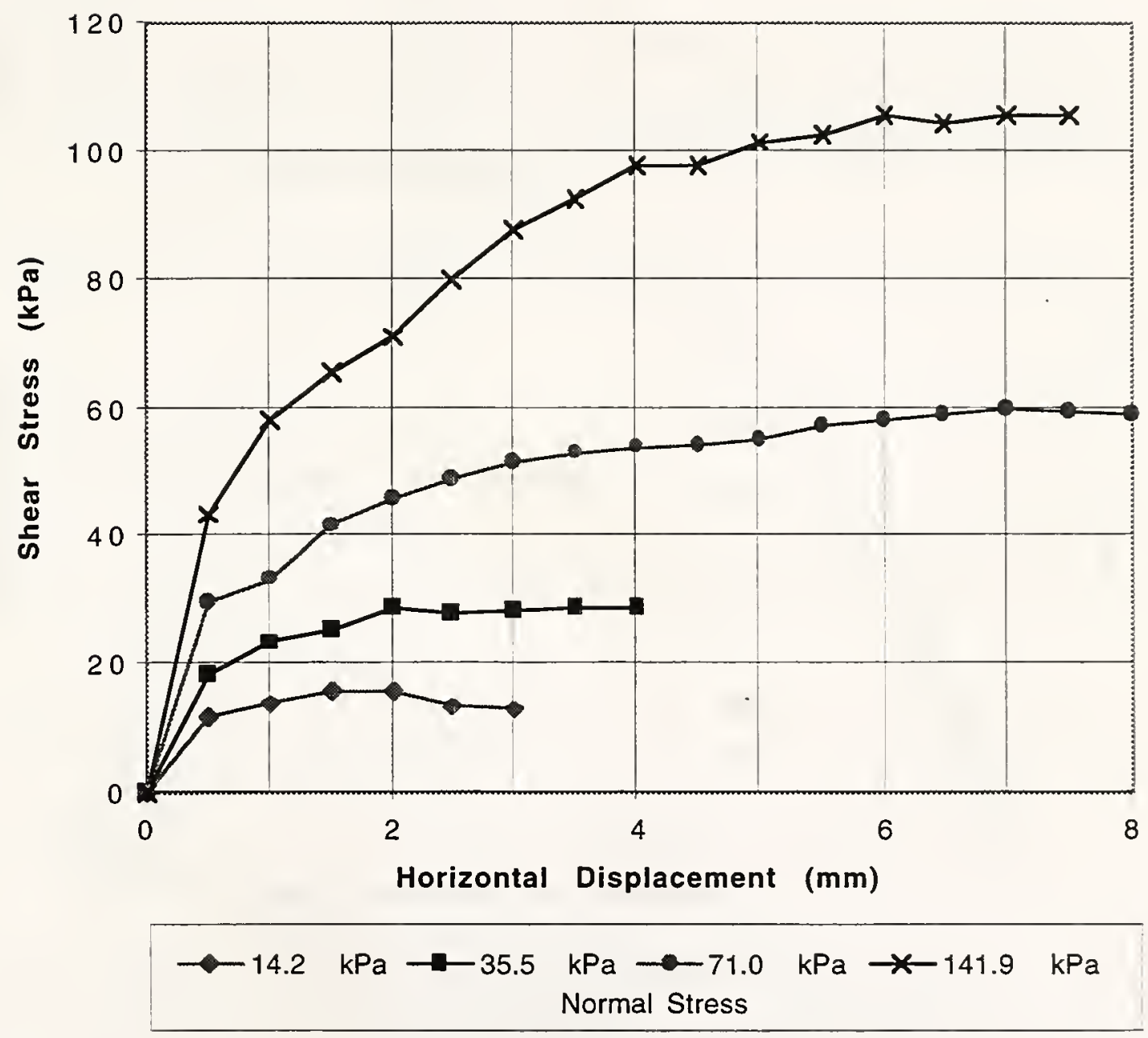

Figure 4.10. Direct Shear Test Results For Loose Weathered WFS (Sample \#1). 


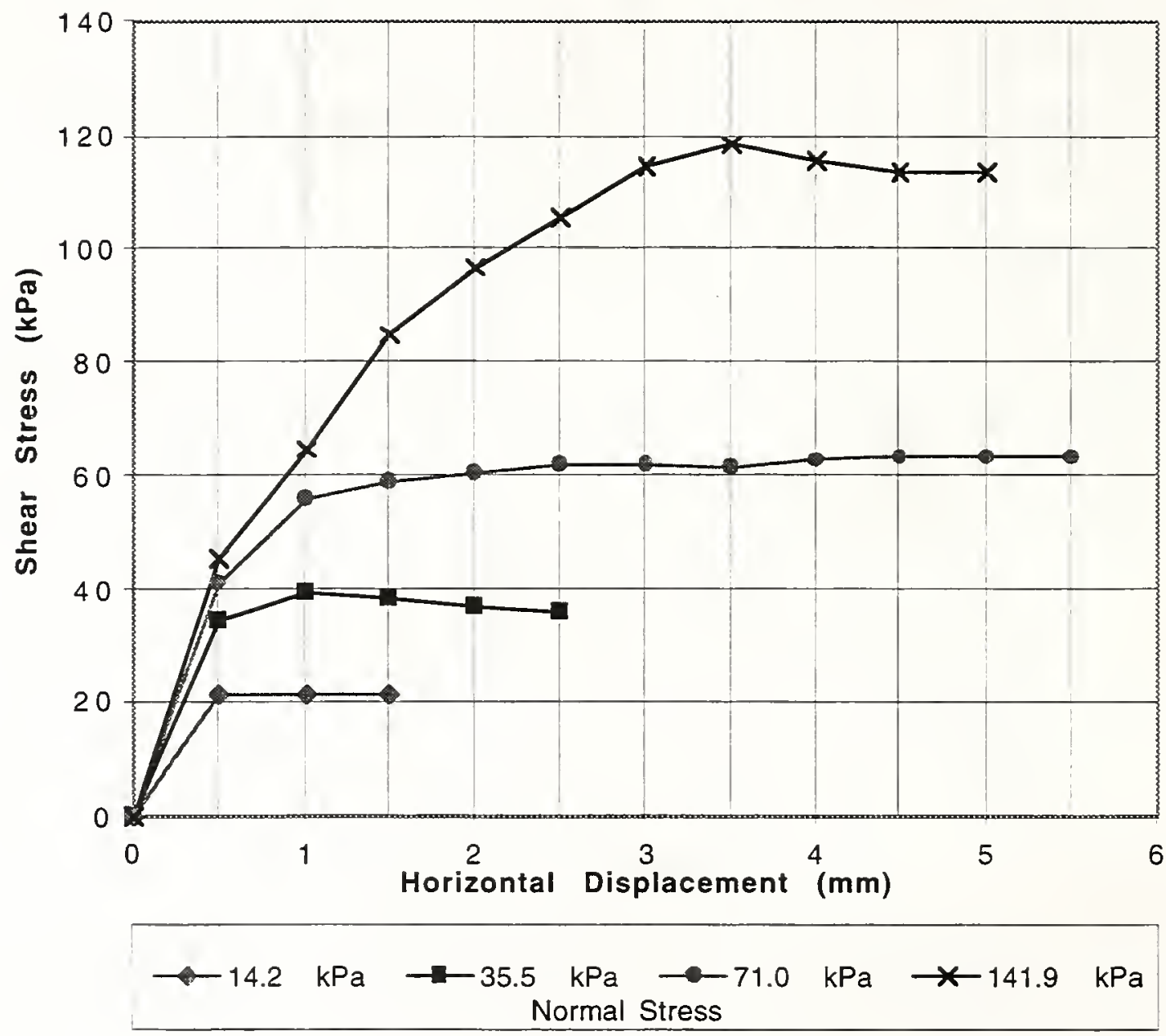

Figure 4.11. Direct Shear Test Results For Dense Weathered WFS (Sample \#1). 


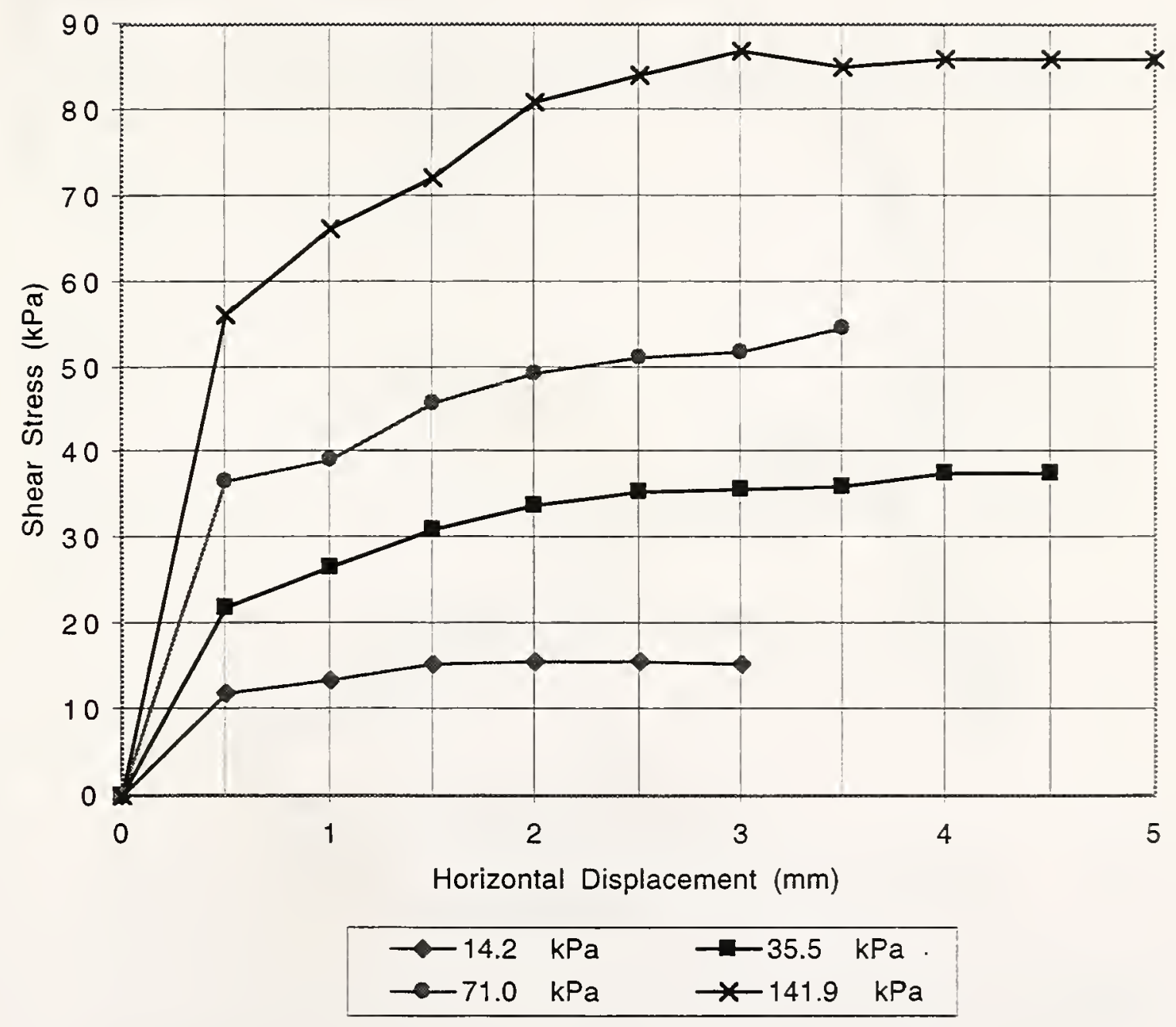

Figure 4.12. Direct Shear Test Results For Loose Fresh WFS (Sample \#1). 


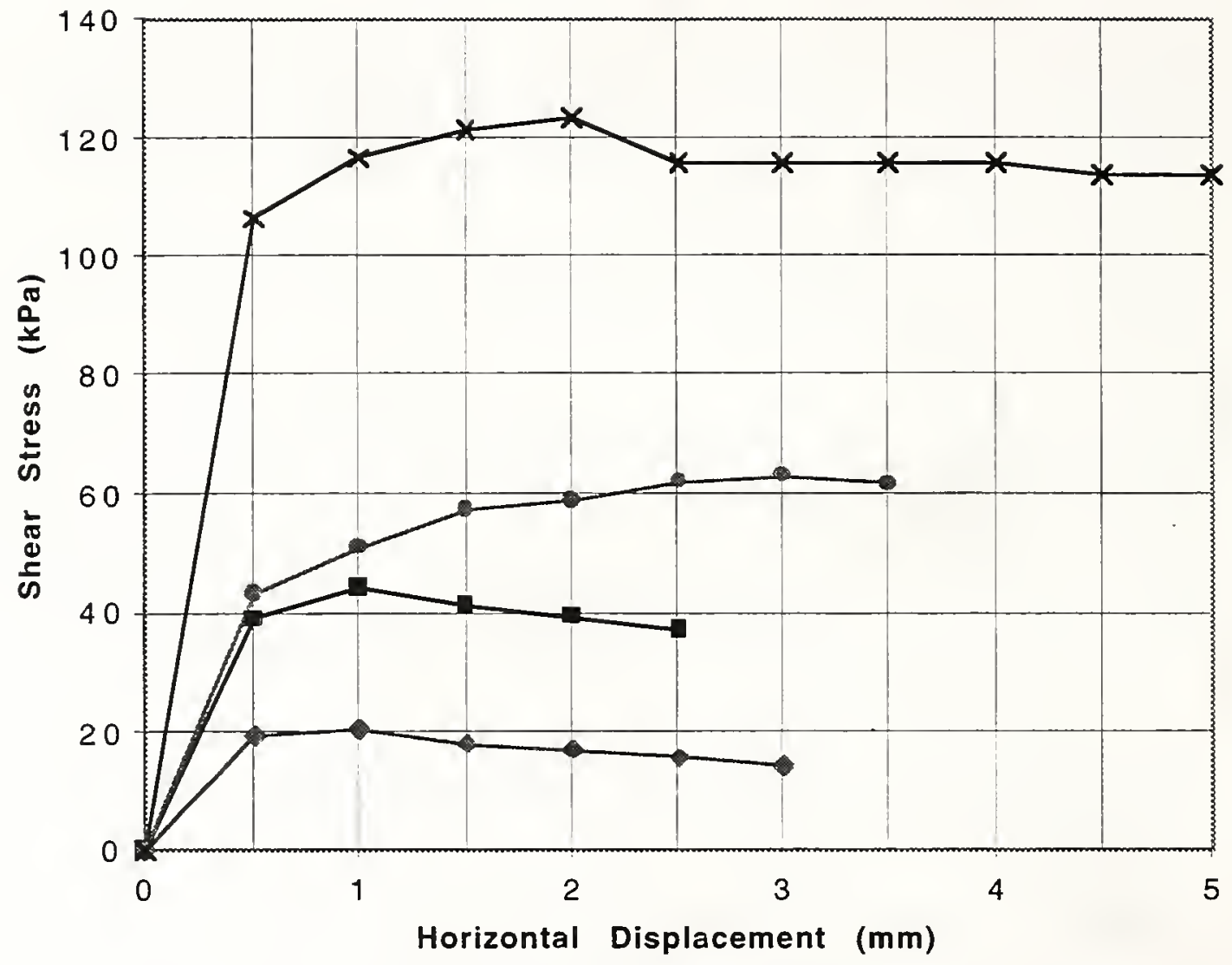

$\longrightarrow-14.2 \mathrm{kPa} \rightarrow-35.5 \mathrm{kPa} \rightarrow-71.0 \mathrm{kPa} \rightarrow-141.9 \mathrm{kPa}$ Normal Stress

Figure 4.13. Direct Shear Test Results For Dense Fresh WFS (Sample \#1). 


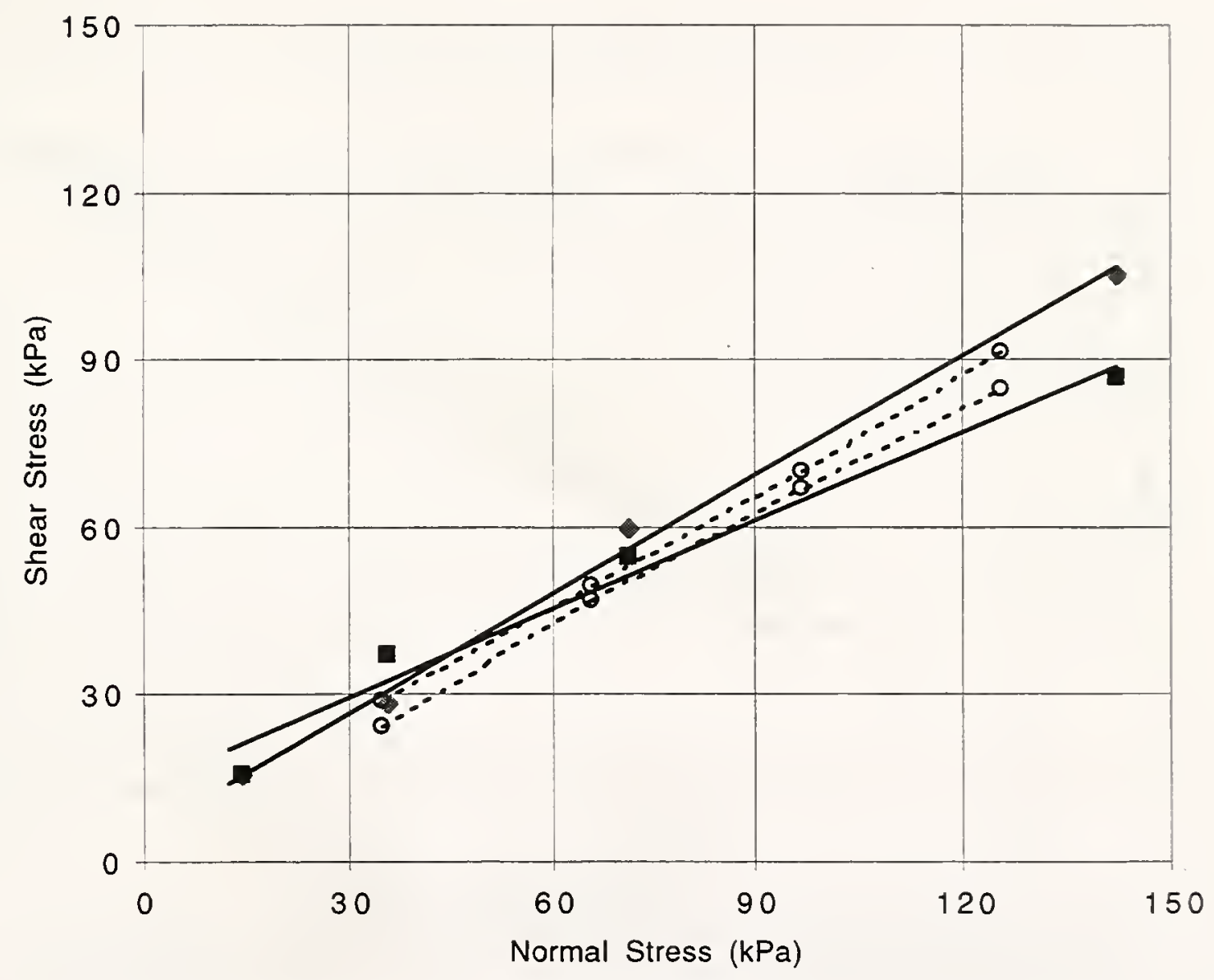

- Weathered WFS a Fresh WFS --๑-- Javed and Lovell (1994)

Figure 4.14. Failure Envelopes for Loose WFS (Sample \#1). 


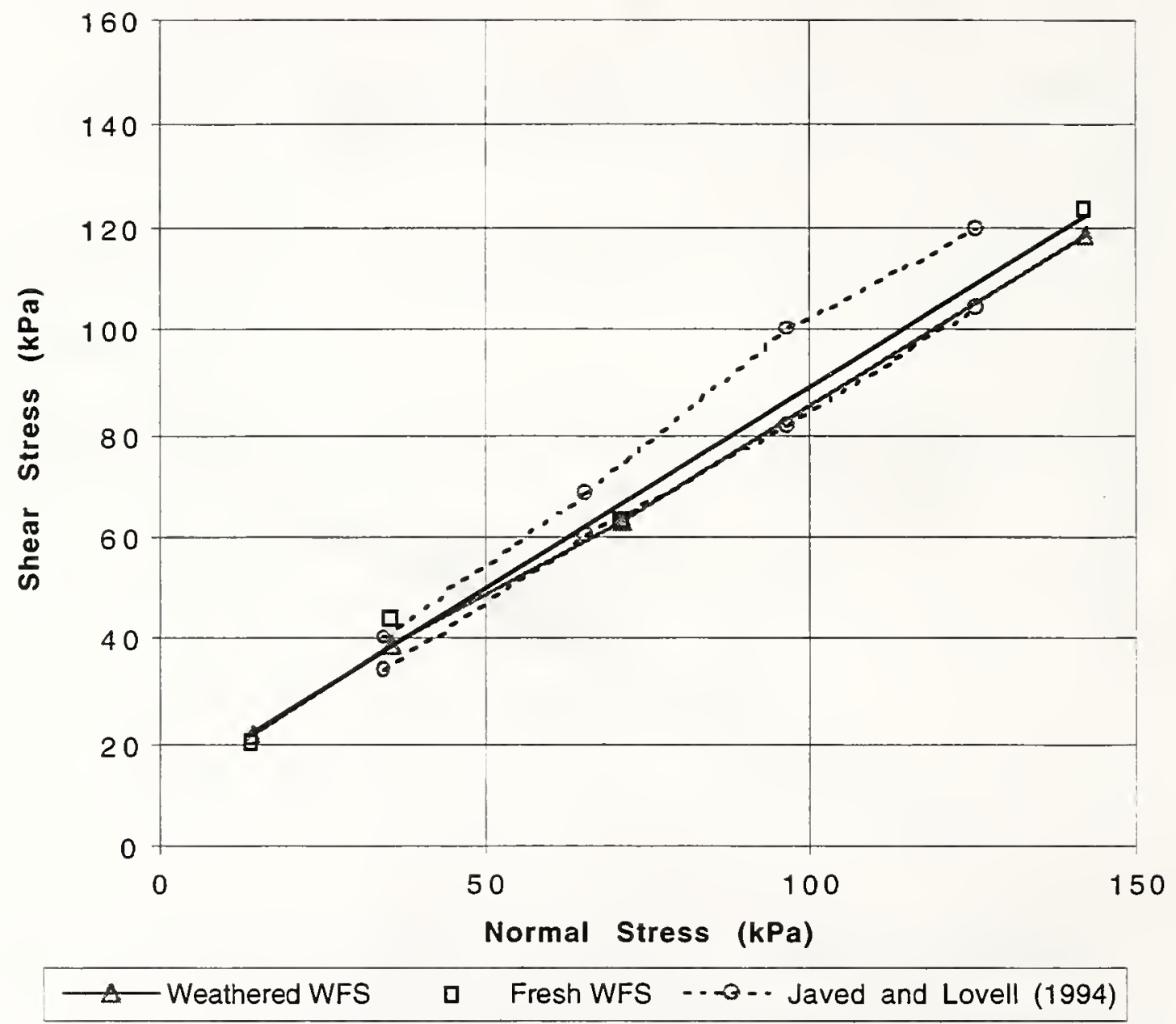

Figure 4.15. Failure Envelopes For Dense WFS (Sample \#1). 
Table 4.4. Results of Direct Shear Tests.

\begin{tabular}{|c|c|c|c|c|c|c|}
\hline \multirow{2}{*}{ Sample } & \multicolumn{3}{|c|}{ Loose Specimen } & \multicolumn{3}{|c|}{ Dense Specimen } \\
\hline & $\mathrm{D}_{\mathrm{r}}(\%)$ & $c^{\prime}(\mathrm{kPa})$ & $\phi^{\prime}(\mathrm{deg})$ & $D_{r}(\%)$ & $c^{\prime}(\mathrm{kPa})$ & $\phi^{\prime}(\operatorname{deg})$ \\
\hline $\mathrm{G1}^{\mathrm{a}}$ & 29 & 4.14 & $\overline{32.4}$ & 90 & 9.93 & 36.6 \\
\hline $\mathrm{G}^{\mathrm{a}}$ & $\overline{34}$ & 5.17 & $\overline{34.2}$ & 98 & 12.55 & 40.9 \\
\hline Weathered WFS & -- & 6.8 & 35 & -- & 13.1 & 38 \\
\hline Fresh WFS & -- & 13.8 & 32.6 & -- & 15.2 & 37 \\
\hline Uniform medium sand $^{5}$ & - & -- & -- & v. dense & 0 & $35-38$ \\
\hline Uniform sand $^{c}$ & loose & $\overline{0}$ & $29-30$ & dense & $\overline{0}$ & $36-41$ \\
\hline $\begin{array}{l}{ }^{\mathrm{a}} \text { From Javed and Lovell } \\
{ }^{\mathrm{b}} \text { From Terzaghi and Pec } \\
{ }^{\mathrm{c}} \text { From Peck, Hanson and }\end{array}$ & $\begin{array}{l}94) . \\
\text { i948). } \\
\text { hornbu. }\end{array}$ & (1974). & & & & \\
\hline
\end{tabular}


. 


\section{CHAPTER 5: FIELD CONSTRUCTION AND TESTING}

\subsection{PRE-CONSTRUCTION INFORMATION}

\subsubsection{Project Site Location}

The WFS embankment was part of the County Route (C. R.) 206 highway project (now designated C. R. 61) in Dekalb County, Indiana. Figure 5.1 shows the general project location and plan view of the research area. The site is $1.6 \mathrm{~km}$ (1 mile) west of Butler, Indiana on State Rt. 6. The site can be located on the U.S.G.S. Butler West quadrangle map, in Township 34 North, Range 14 East, Section 10. C. R. 206 is a two-lane, rural road approximately $7.4 \mathrm{~km}$ long. It was built primarily for heavy truck traffic making deliveries to Steel Dynamics, Inc., a steel recycling plant at the south end of C. R. 206.

\subsubsection{Geology and Subsurface Conditions}

The bedrock geology of the site is described by the Indiana Geological Survey Bedrock Geology Map, Fort Wayne Quadrangle. The site is underlain the Antrim Shale Formation at a depth of $67 \mathrm{~m}$. Antrim Shale is a black shale with gray shale and limestone. The unconsolidated deposits above the bedrock are primarily glacial in origin. The Geologic Map of Unconsolidated Deposits designates the soil on this site as Qcl (clay, silt, sand; lacustrine deposit), and Qte (end-moraine deposits). This region is within the Stueben Morainal Region of Indiana. Observations made in the field indicate that drainage of the WFS project area occurs mainly by farm field tiles and a ditch running immediately south of the railroad tracks. There are a number of wetlands in the area. Several of these wetlands were moved as part of this project, including one which was relocated inside of the loop at the north end of the project. Construction was delayed at times in other portions of the road section due to peats and organic soils in the foundation soils.

On August 24, 1995, soil borings were obtained by INDOT in order to evaluate the subsurface conditions under the proposed roadway. These borings were drilled using a hollow stem auger (HSA). Standard Penetration Tests (SPT) were performed and samples were collected for 

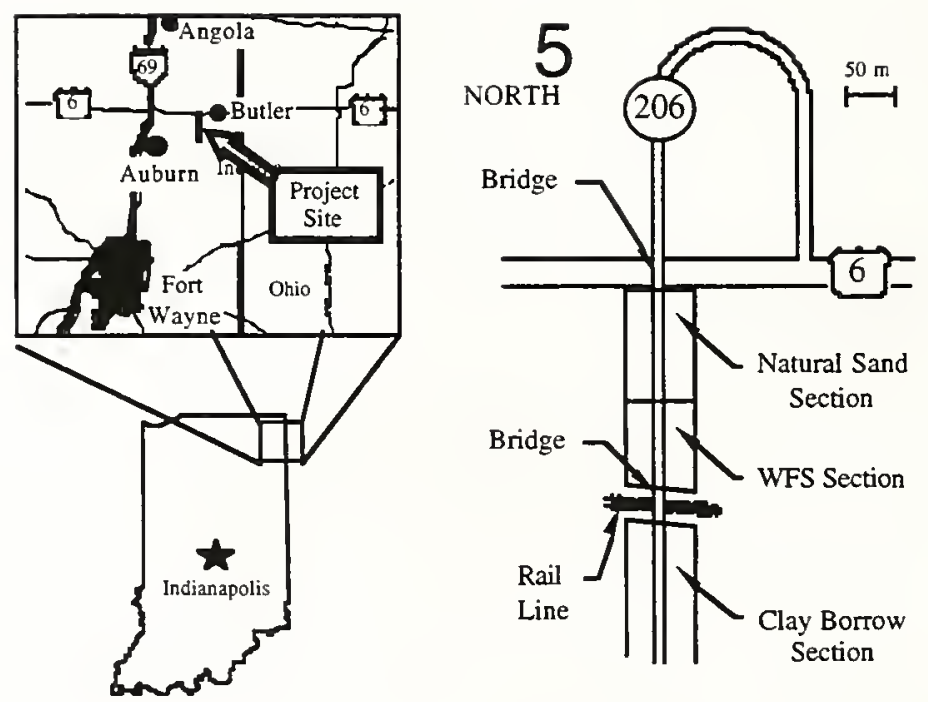

Figure 5.1. Project Location and Plan View. 
laboratory analyses. In addition to the HSA borings, shallow investigations were performed using a flight auger. The borings which are relevant to the WFS project are listed in Table 5.1 and discussed below. The boring logs are provided in Appendix A.

The INDOT soil borings show medium stiff loam extending from 0.3 to $0.6 \mathrm{~m}$ below the ground surface. Next is a moist, loose sand from 0.6 to $1.5 \mathrm{~m}$, and then stiff loam from 1.5 to $2.4 \mathrm{~m}$. Extending from 2.4 to $3.6 \mathrm{~m}$, a medium dense sand was found, and then a moist, very stiff to hard clay from 3.6 to $8.2 \mathrm{~m}$. Finally, a medium dense sand and gravel from 8.2 to 10.7 $\mathrm{m}$ was encountered. The groundwater table was measured at approximately $1.5 \mathrm{~m}$ below ground surface (elevation $266.7 \mathrm{~m}$ ) in several of the borings. Organic soils were not identified in the foundation soils of the test section.

\subsubsection{Embankment Plans and Drawings}

The project test section is a $274 \mathrm{~m}$ portion of C. R. 206 and is divided into three subsections. The southernmost subsection was built using clay soil from a local borrow pit. The center subsection, approximately $114 \mathrm{~m}$ long, $85.3 \mathrm{~m}$ wide, and $9.1 \mathrm{~m}$ high, was built using WFS from the Auburn Foundry monofill. The northernmost subsection was built using natural sand which met the INDOT specification for B-Borrow. B-Borrow is often used as a freelydraining backfill behind structures such as retaining walls and bridge abutments.

Figure 5.2 presents a schematic diagram of the site, including station numbers along the road centerline. Two rail lines, represented as one track, are located at STA 345+50. State Route 6 is shown at STA $353+50$, running east and west. The clay borrow section of the project is immediately south of the rail lines, starting at STA $342+00$. The WFS and B-Borrow sections together extend from the railroad tracks north to Route 6. The interface of WFS and B-Borrow embankment sections was a 1:1 slope centered at STA $349+25$.

\subsubsection{Instrument Locations}

Figure 5.3 presents a simplified plan view of the project site with the settlement plate set locations. Each set consisted of three settlement plates. The first settlement plate was located 
Table 5.1. INDOT HSA Soil Borings for Project Site.

\begin{tabular}{|c|c|c|}
\hline Boring Number & Station and Offset & Depth $(\mathrm{m})$ \\
\hline FS - 1 & $348+00$ on Centerline & 10.7 \\
\hline FS - 2 & $351+00$ on Centerline & 10.7 \\
\hline FS - 3 & $350+00$ on Centerline & 10.7 \\
\hline FS - 4 & $350+50$ on Centerline & 10.7 \\
\hline FS - 5 & $349+50$ on Centerline & 10.7 \\
\hline FS - 6 & $352+00$ on Centerline & 10.7 \\
\hline
\end{tabular}




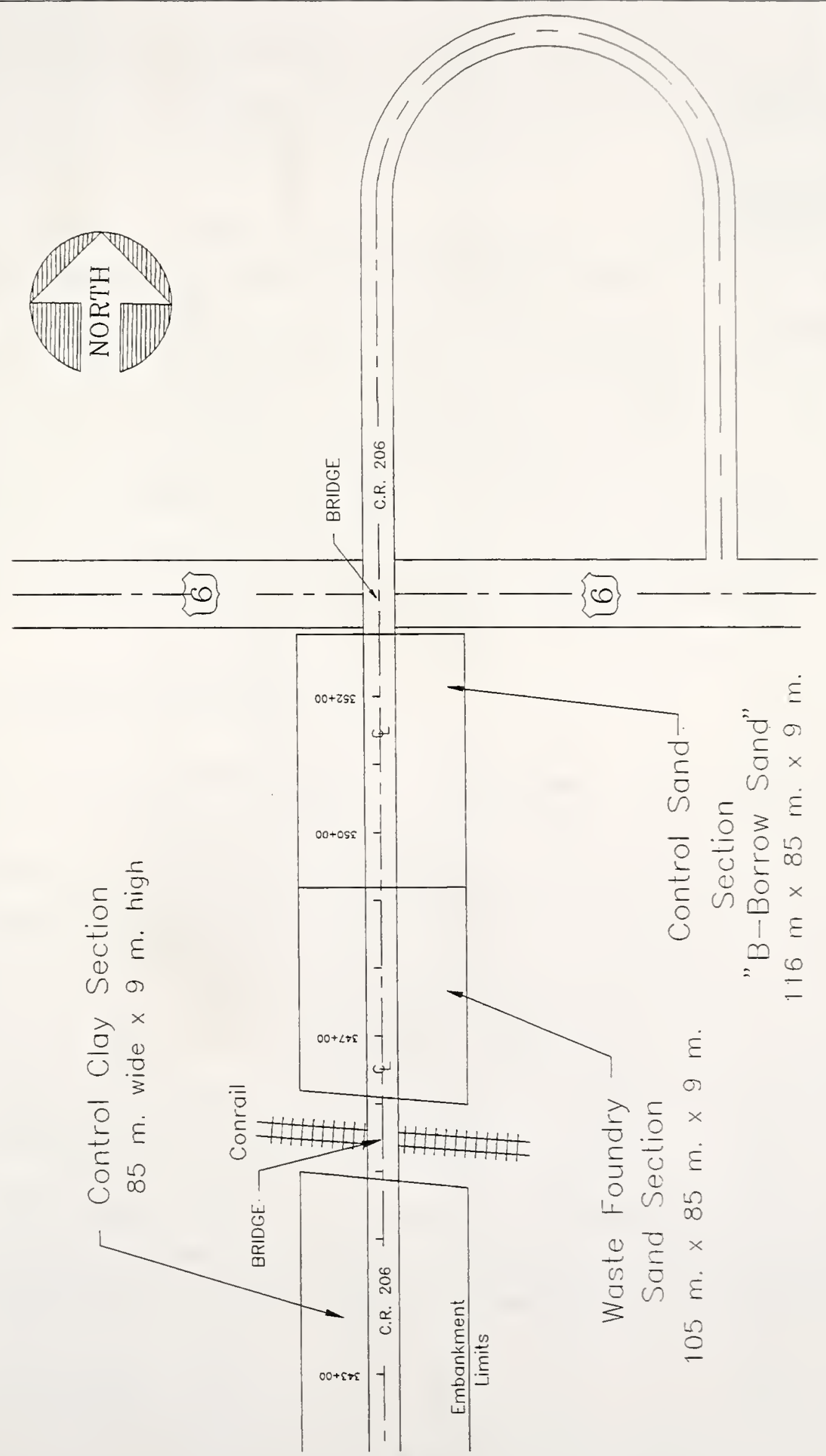

ن 


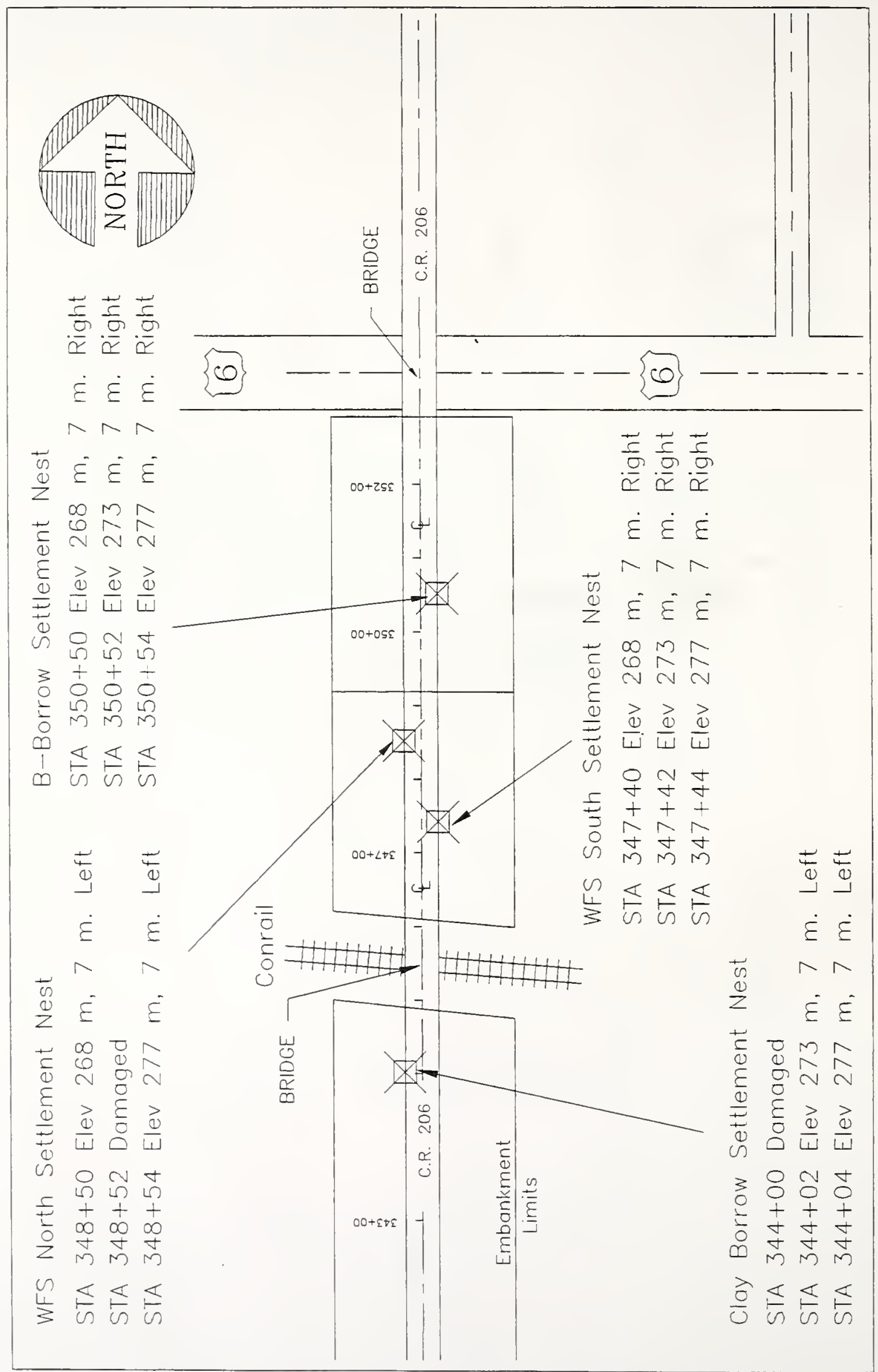

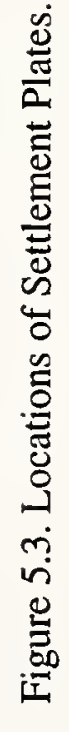


on top of the foundation soils, generally at an elevation of 268.2 mean sea level. The second set was located at the mid-height of the embankment at elevation $272.8 \mathrm{~m}$. Finally, the top settlement plate was located near the top of the embankment fill.

Figure 5.4 presents a simplified plan drawing of the project site showing the remaining geotechnical instrumentation locations. Figure 5.5 presents simplified cross-sections showing the geotechnical instrumentation. Two piezometers were installed prior to construction at a depth of $6.1 \mathrm{~m}$ below original grade. Two vertical slope inclinometers were installed to a depth of $15.2 \mathrm{~m}$ below the original grade. Two total pressure cells were installed at the foundation elevation. Finally, two horizontal inclinometers were installed in the embankment. The first horizontal inclinometer was installed under the entire width of the embankment at the foundation soil elevation (approximately $268.2 \mathrm{~m}$ ). The second horizontal inclinometer was installed at elevation $273.7 \mathrm{~m}$, approximately at $2 / 3$ of the height of the embankment.

\subsection{CHRONOLOGY OF WFS PROJECT}

Figure 5.6 presents a chronology of major events for the project. The first period of activity began with soil borings in May, 1995, and continued to the completion of WFS placement. The preconstruction and construction operations occurred during the late spring, summer, and early fall of 1996. Geotechnical instruments were installed in the embankment as construction proceeded. The WFS section was completed on August 15 and cover soils were placed until October 3, 1996. The majority of the earth-moving operations were completed in late November, 1996. A total of $42,810 \mathrm{~m}^{3}\left(56,000 \mathrm{yd}^{3}\right)$ of WFS was placed in the embankment. For comparison, approximately $34,790 \mathrm{~m}^{3}\left(45,500 \mathrm{yd}^{3}\right)$ of B-Borrow were placed in the embankment for the control section of the embankment.

The second period of activity was post-construction. Monitoring of the geotechnical instruments continued after construction at monthly intervals until January, 1997. Thereafter, the monitoring interval was extended to bi-monthly and then approximately every 6 months 


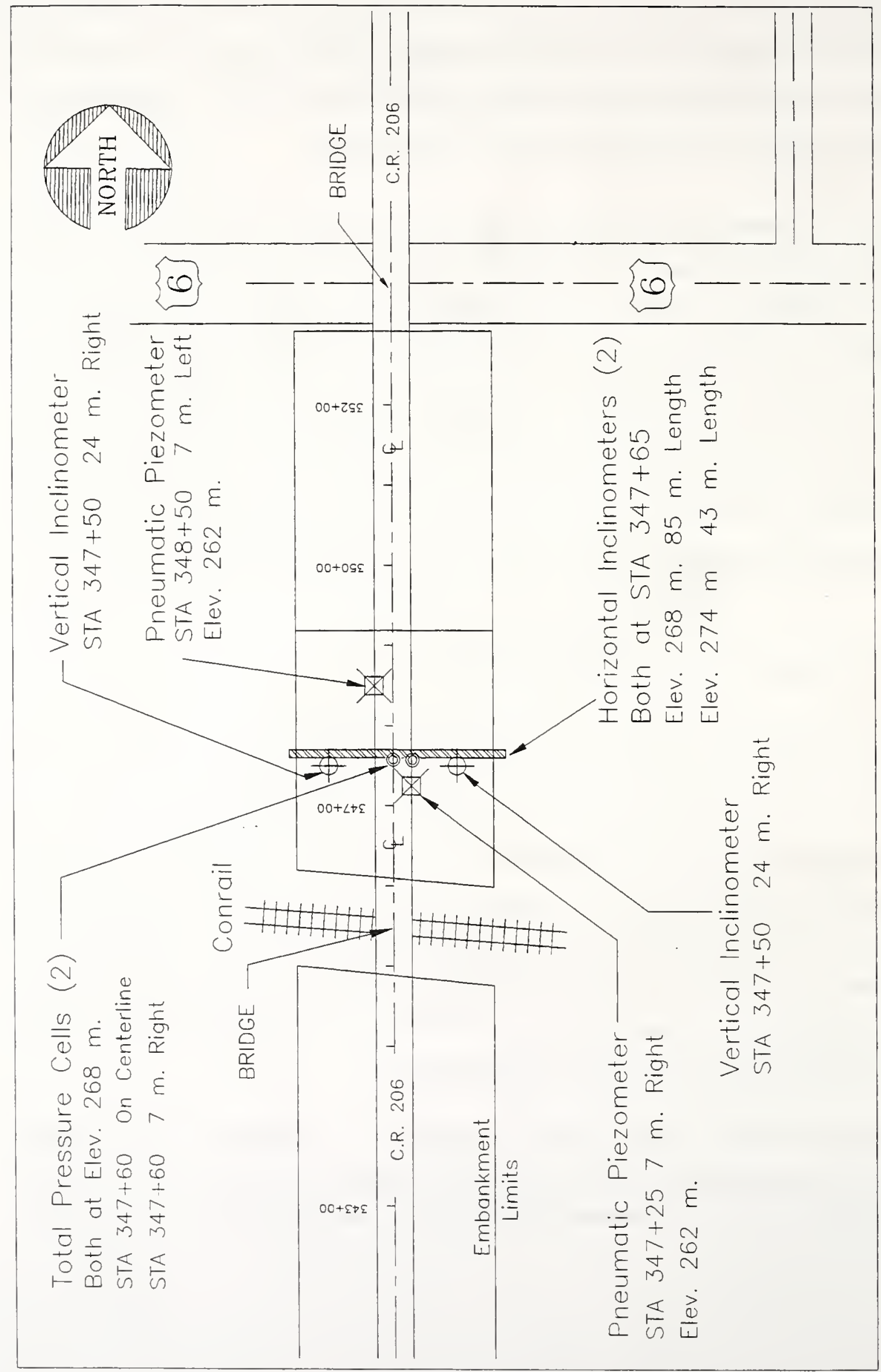

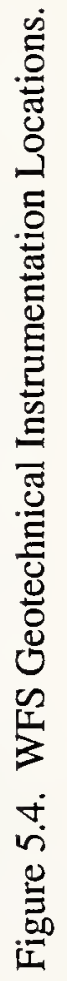



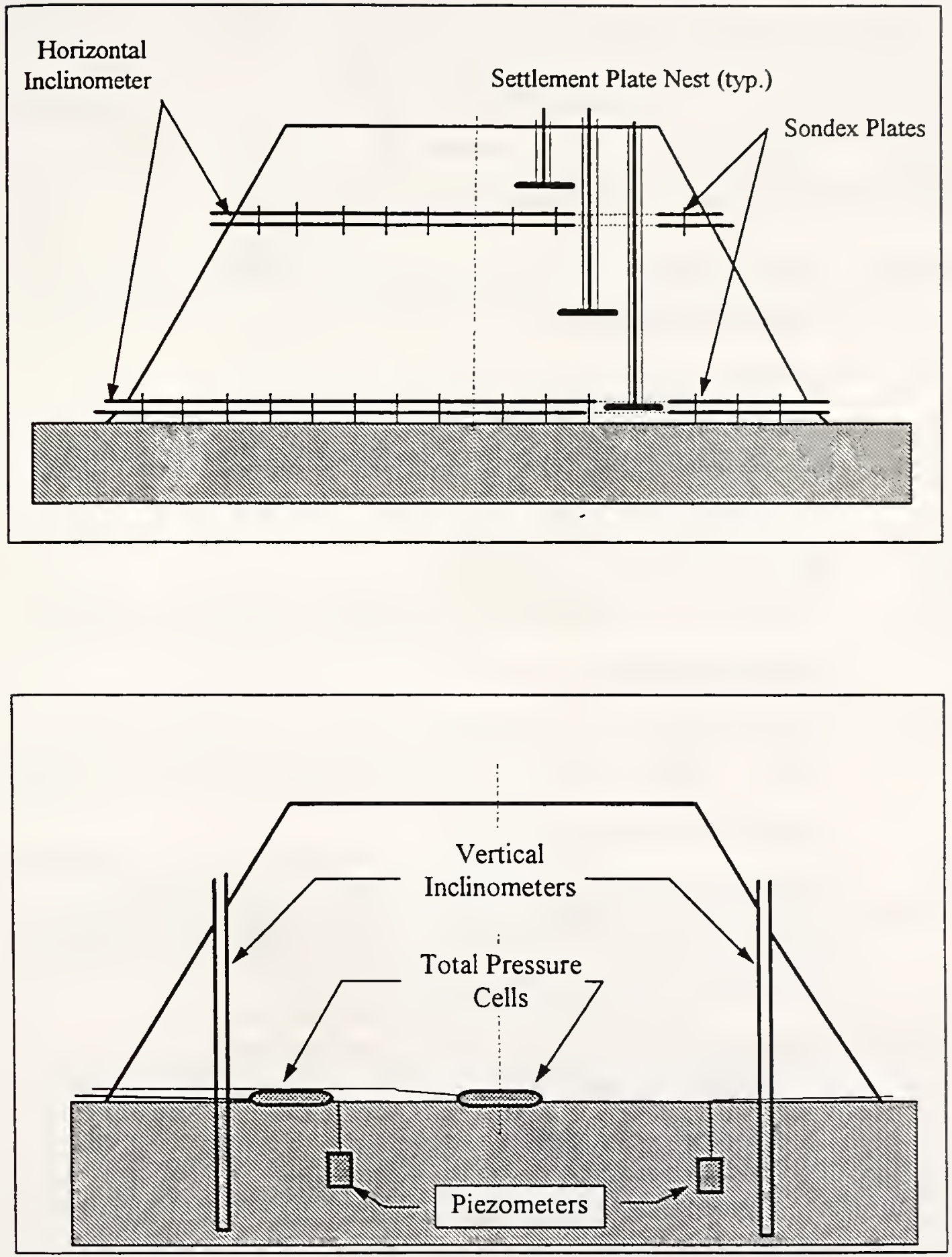

Figure 5.5. WFS Geotechnical Instruments. 
$\underline{1995}$

- August 23 First site visit with INDOT personnel.

- August 24 INDOT soil borings drilled for subsurface investigation.

- September 26 Collected Shelby tubes and bag samples from INDOT borings for laboratory investigation.

- November INDOT withdrew plans to reuse WFS on C. R. 206.

\section{6}

- Spring INDOT reinstated the WFS project.

- May 16 Purdue University personnel meet with INDOT geotechnical engineers to plan instrumentation.

- May 23 Pre-construction meeting with representatives from Fox Contractors, INDOT, Purdue University, and Auburn Foundry to discuss project plans and address questions about WFS.

- May 30 Construction of a test pad at Auburn Foundry monofill to determine method specification for compaction of WFS. INDOT, Fox Contractors, and Purdue University personnel attended.

- June 24-26 Site clearing and installation of the following instruments:

2 vertical slope inclinometers

2 pneumatic piezometers

6 groundwater monitoring wells

2 surveying benchmarks at the edges of the site

- July 12 First readings on vertical slope inclinometers.

Figure 5.6. Chronology of WFS Project. 
- July 15 a) First load of WFS arrives on site, embankment construction begins.

b) First settlement plates placed on foundation level (elev. $268.2 \mathrm{~m}$ ).

- July 22 a) East vertical inclinometer damaged by a truck; it was repaired and readings continued.

b) Settlement plate at $350+50$ was damaged by a truck, repaired by INDOT personnel.

- July 23 a) Dug a trench into existing WFS fill to place the bottom horizontal inclinometer.

b) Dug two large pits to place the total pressure cells.

- July 24 a) Completed installation of horizontal inclinometer and pressure cells.

b) Added additional lengths to vertical inclinometers.

- July 29 a) INDOT reports that settlement plate at STA $348+40$ was damaged by a truck and replaced.

b) Performed first reading of bottom horizontal inclinometer.

- August 1 Fox Contractors placed settlement plate at STA $347+45$, elev. $270.4 \mathrm{~m}$ (middle plate in the three-plate set).

- August 7 Installed top horizontal inclinometer.

- August 8 a) Performed sand cone/nuclear density gauge comparison tests on WFS embankment.

b) First reading of top horizontal inclinometer.

- August 15 WFS placement finished, placement of cover soil began.

- August 22 West vertical inclinometer was damaged and repaired.

- August 31 Installed the sealed double ring infiltrometer (SDRI). 
- September 12 a) Disassembled SDRI to check for problems.

b) Reassembled SDRI to continue test.

- September 27 Found east vertical inclinometer buried under cover soil. It may have been damaged by bulldozers.

- October 3 SDRI disassembled and removed.

- October 24 Discovered damaged settlement plates at STA 344+00 and STA 347+52; cause unknown.

- December 3 C. R. 206 opened to traffic.

- January 20 Read instruments.

- March 13 Read instruments.

- May 14 Read instruments.

- October 19 Read instruments.

1998

- May 2 Read instruments.

- June 6 Last site visit. Read vertical inclinometers for verification of data.

Figure 5.6. (cont.) 
after May, 1997. The third period of activity was monitoring of the embankment until June, 1998.

\subsection{FIELD COMPACTION TESTING}

\subsubsection{Compaction Test Pad at Auburn Foundry Monofill}

The strength and compressibility of a fill material are significantly improved by compaction. Laboratory testing is generally used to establish the optimum moisture content (OMC) and maximum dry unit weight $\left(\gamma_{d, \max }\right)$ of a construction material. The water content and dry unit weight are then checked during construction by field testing personnel in order to assure that the material is within an acceptable range. For this project, there was some concern that the nuclear density gauge would be affected by metallic elements in the WFS. Other field compaction testing methods, such as the sand cone and water balloon methods, are considerably more difficult to perform in WFS than in most natural soils due to the large particles in the WFS. Specifically, it was difficult to excavate a clean hole in the WFS without developing large voids in the side wall. A stable, clean hole is necessary for volume measurements by these methods.

As a result of these concerns, INDOT decided to implement a method specification for compaction on the C. R. 206 project. Using field test pads prior to construction, water content, equipment type, and the number of passes were varied to study their effect on the dry unit weight of the material. From these tests, a method of achieving acceptable compaction was chosen for construction.

On May 30, 1996, INDOT, Purdue University, and Fox Contractors personnel met at the Auburn Foundry monofill to build two WFS test pads. The pads were placed on the uncompacted ground surface at the north end of the monofill site. Figure 5.7 presents a schematic diagram of the test pads and the data collected from testing. The northern test pad (Test Pad 1) was compacted using a vibratory smooth drum roller. The southern test pad (Test 

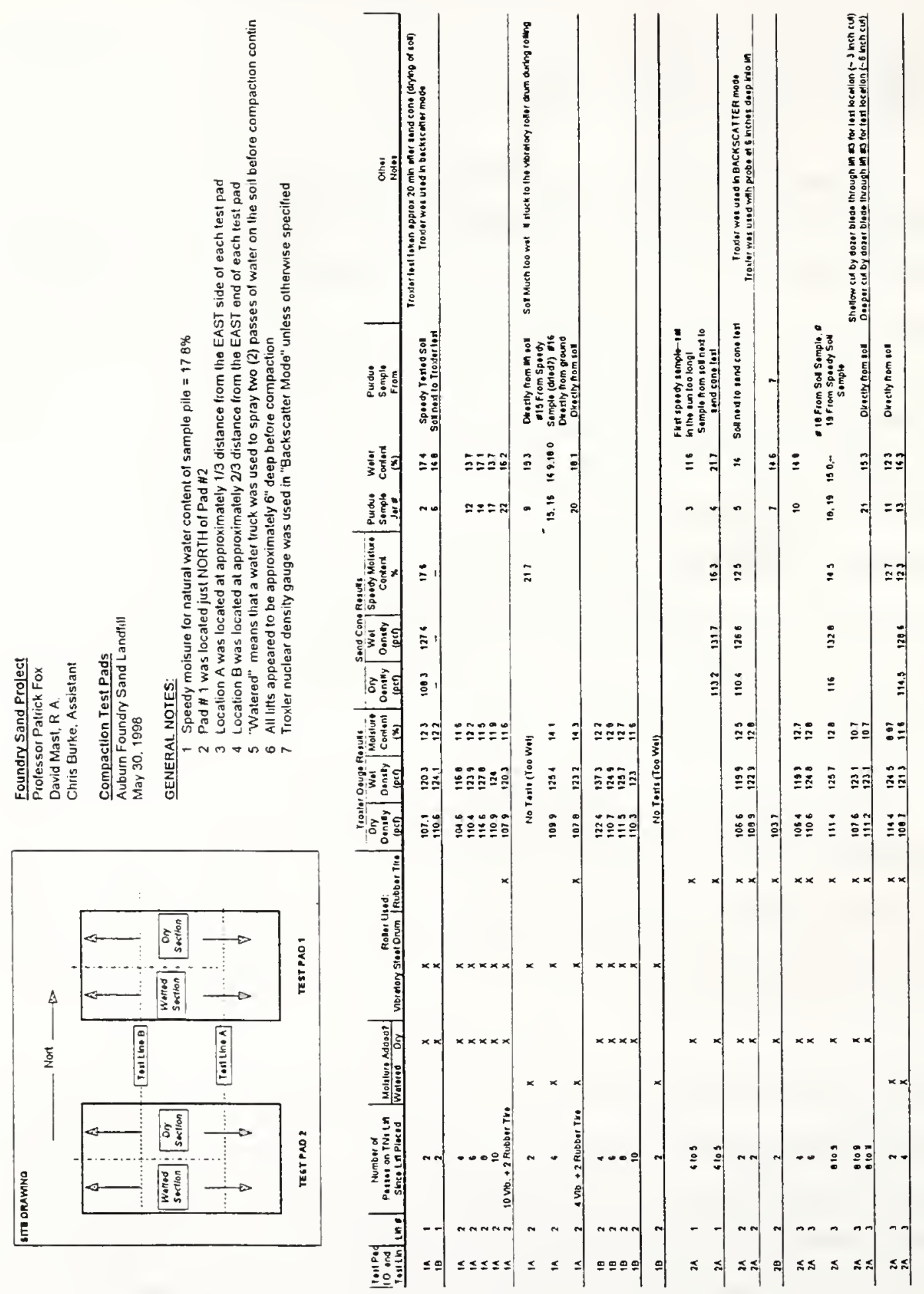

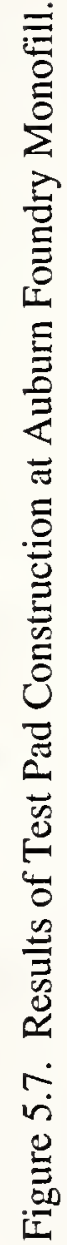


Pad 2) was compacted using a $354 \mathrm{kN}(79,500 \mathrm{lb}$.) rubber-tire roller. The procedure was to compact each pad with one pass of the roller and test the dry unit weight and moisture content along lines $\mathrm{A}$ and $\mathrm{B}$ (Figure 5.7). This procedure was repeated for a total of 10 passes. A "pass" is defined by INDOT specifications as one crossing of the roller over a given location. In order to evaluate the effect of water content, one half of each test pad was watered and then compacted with the same number of passes as the dry side. These field tests resulted in the following method specification:

1. Each embankment lift of WFS shall receive a minimum of 6 passes with the pneumatic (rubber)-tire roller. The weight of the roller should be $354 \mathrm{kN}(79,500 \mathrm{lb}$.) with a tire pressure of $206.8 \mathrm{kPa}(30 \mathrm{psi})$.

2. During compaction, the moisture content of the WFS shall be maintained between $12 \%$ and $15 \%$.

3. Prior to compaction, the WFS shall be placed in $200 \mathrm{~mm}$ ( 8 inch) lifts.

In addition to the method specification, the INDOT geotechnical engineers noted that moisture content should be determined in the field using the Speedy Moisture Meter, with a correction factor of -1 percentage point. The field engineers were instructed not to rely on the nuclear density gauge to evaluate the in situ dry unit weight of the WFS unless a new calibration was developed for WFS.

\subsubsection{Field Compaction Testing Results}

In order to evaluate the success of the method specification, INDOT field personnel performed in situ unit weight tests during construction. Figure 5.8 presents field and laboratory compaction test results for the Auburn WFS. This figure shows good agreement between field test data and laboratory Proctor curves for WFS Sample \#2. The WFS reached a minimum relative compaction of $100 \%$ standard Proctor. This figure suggests that the Method B standard and modified Proctor tests provided a good estimate of the compacted unit weight of WFS in the field. 


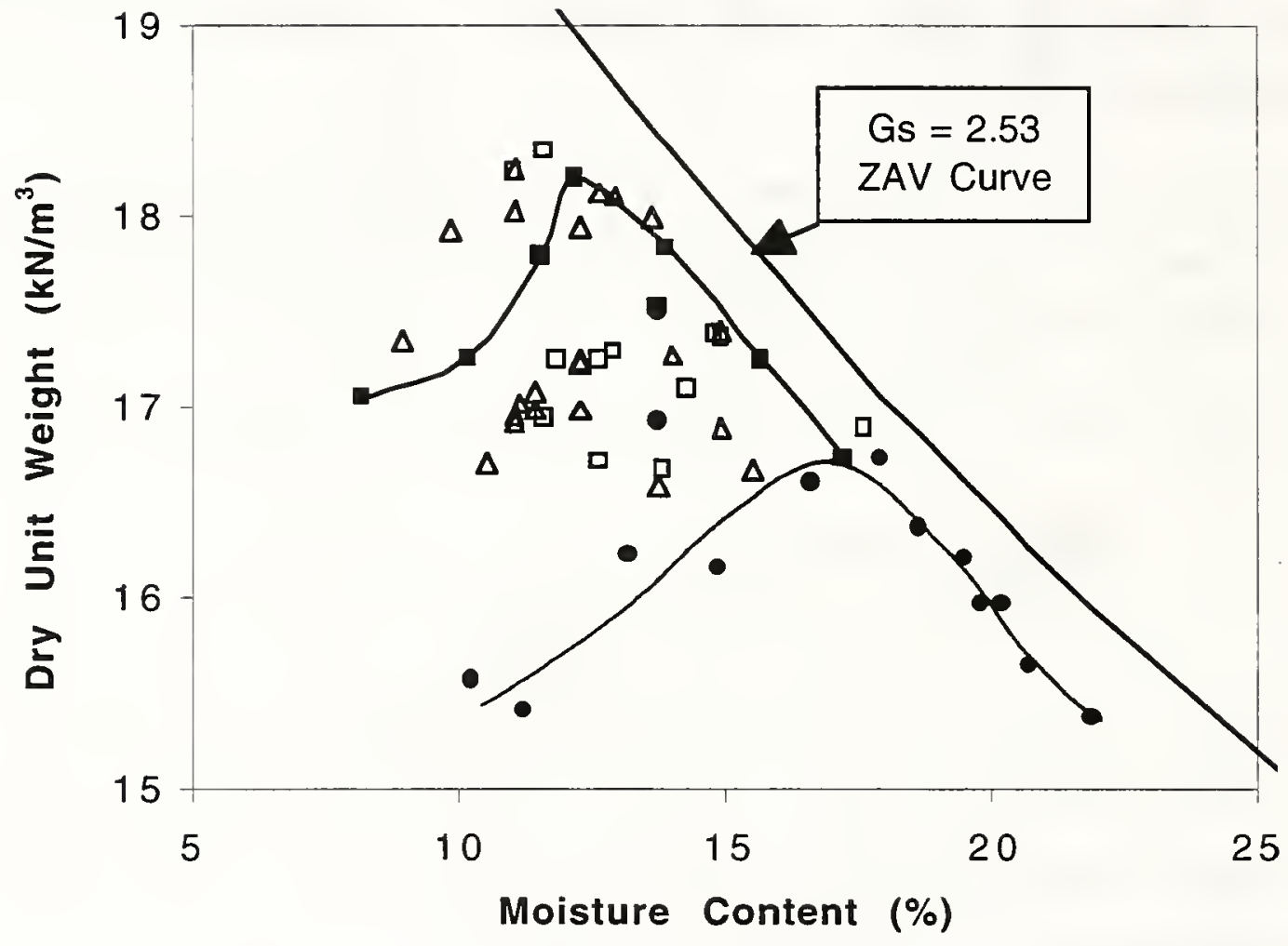

$\multimap$ Laboratory Std. Proctor $\rightarrow$-Laboratory Mod. Proctor $\Delta$ Sand Cone $\quad \square$ Nuclear Density Gauge

Figure 5.8. Field and Laboratory Compaction Data for Auburn WFS. 
Dry unit weight values for the nuclear density gauge and sand cone test methods had similar patterns over the construction period. A frequency plot (dry unit weight versus number of occurrences) showed test results grouped into two peaks, one at approximately $15.8 \mathrm{kN} / \mathrm{m}^{3}$, and a second at approximately $16.7 \mathrm{kN} / \mathrm{m}^{3}$ (Mast 1997). A plot of calendar date vs. dry unit weight for this data showed that peak values did not occur in any single week, suggesting they are good indications of the average level of compaction achieved throughout the testing period. The moisture content data from the same tests showed a fairly random pattem until August 6 , 1996, after which time most Speedy Moisture Tests were approximately $11.5 \%$. In general, WFS moisture contents during embankment construction were between $10.5 \%$ and $15 \%$.

\subsubsection{Comparison of Field Compaction Test Methods}

On August 6, 1996, a $3.6 \mathrm{~m}$ by $3.6 \mathrm{~m}$ test section was prepared on the WFS embankment for the purpose of comparing the results of nuclear density gage tests with sand cone and Speedy Moisture Meter (SMM) tests. Six nuclear density gauge tests were performed adjacent to six sand cone tests. The nuclear density gauge tests were performed in direct transmission mode. Figure 5.9 shows a photograph of the test section after the tests were completed. The nuclear density gauge tests and sand come tests are shown by rectangular and circular outlines, respectively. Each sand cone test had a corresponding Speedy Moisture Meter test. In addition, a sample from the sand cone hole was oven dried to obtain moisture content. Table 5.2 presents the numerical results for these tests.

Figure 5.10 compares the nuclear density gauge and the sand cone wet unit weight test values. This figure includes results from the $3.6 \mathrm{~m}$ by $3.6 \mathrm{~m}$ test pad as well as random tests which were performed side-by-side during construction of the embankment. Corresponding dry unit weights are shown in Figure 5.11. The open squares show nuclear density gauge dry unit weights plotted against sand cone dry unit weights calculated using SMM moisture contents. The solid circles show the same nuclear density gauge dry unit weights plotted against sand cone dry unit weight values calculated using oven-dry moisture contents. The triangles show the random side-by-side tests, for which sand cone dry unit weights were obtained using the SMM. The nuclear density gauge dry unit weight measurements agree well with the sand cone 


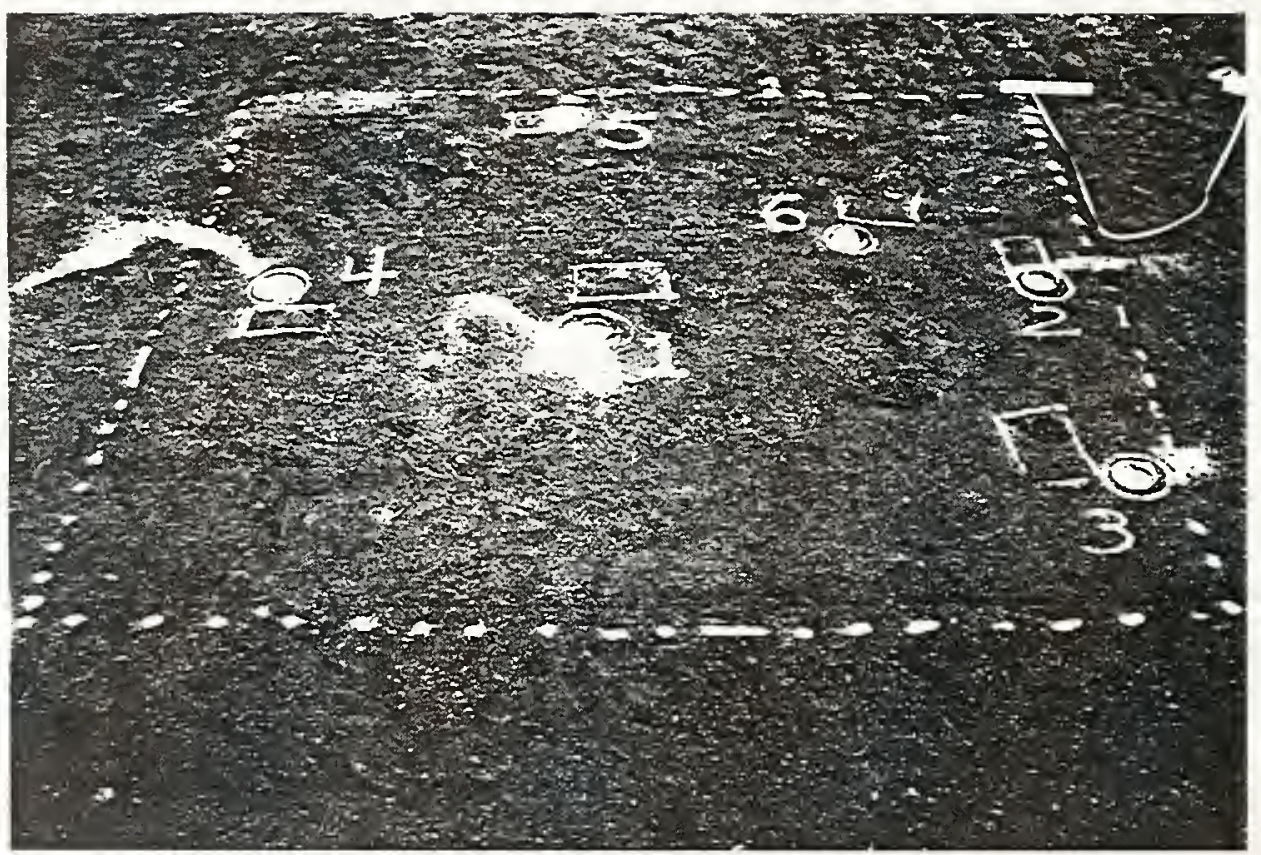

Figure 5.9. Photograph of WFS Compaction Test Section at Project Site. 
Table 5.2. Data from WFS Project Site Compaction Test Section.

\begin{tabular}{|c|c|c|c|c|c|c|c|c|}
\hline & \multicolumn{3}{|c|}{ Nuclear Density Gauge } & \multicolumn{3}{|c|}{ Sand Cone Test } & Oven & \\
\cline { 2 - 9 } & $(\mathrm{a})$ & $(\mathrm{b})$ & $(\mathrm{c})$ & $(\mathrm{d})$ & $(\mathrm{e})$ & $(\mathrm{f})$ & $(\mathrm{g})$ & $(\mathrm{h})$ \\
\hline $\begin{array}{c}\text { Test } \\
\#\end{array}$ & $\begin{array}{c}\gamma \\
\left(\mathrm{kN} / \mathrm{m}^{3}\right)\end{array}$ & $\begin{array}{c}\mathrm{w} \\
(\%)\end{array}$ & $\begin{array}{c}\gamma_{\mathrm{d}} \\
\left(\mathrm{kN} / \mathrm{m}^{3}\right)\end{array}$ & $\begin{array}{c}\gamma \\
\left(\mathrm{kN} / \mathrm{m}^{3}\right)\end{array}$ & $\begin{array}{c}\mathrm{SMM} \\
\mathrm{w}\end{array}$ & $\begin{array}{c}\gamma_{\mathrm{d}} \\
\left(\mathrm{kN} / \mathrm{m}^{3}\right)\end{array}$ & $\begin{array}{c}\mathrm{w} \\
(\%)\end{array}$ & $\begin{array}{c}(\mathrm{g})-(\mathrm{e}) \\
\Delta \mathrm{w}(\%)\end{array}$ \\
\hline 1 & 18.2 & 11.1 & 16.4 & 18.1 & 10.2 & 16.4 & 11.8 & 1.6 \\
\hline 2 & 18.7 & 8.7 & 17.2 & 18.7 & 10.2 & 17.0 & 10.5 & 0.3 \\
\hline 3 & 17.9 & 10.2 & 16.3 & 18.8 & 13.7 & 16.5 & 11.6 & 2.1 \\
\hline 4 & 18.6 & 8.6 & 17.1 & 19.0 & 11.4 & 17.1 & 12.2 & 0.8 \\
\hline 5 & 18.5 & 8.0 & 17.2 & 18.9 & 10.0 & 17.1 & 9.7 & 0.3 \\
\hline 6 & 18.8 & 9.7 & 17.1 & 18.9 & 13.7 & 16.6 & 12.4 & 1.3 \\
\hline
\end{tabular}




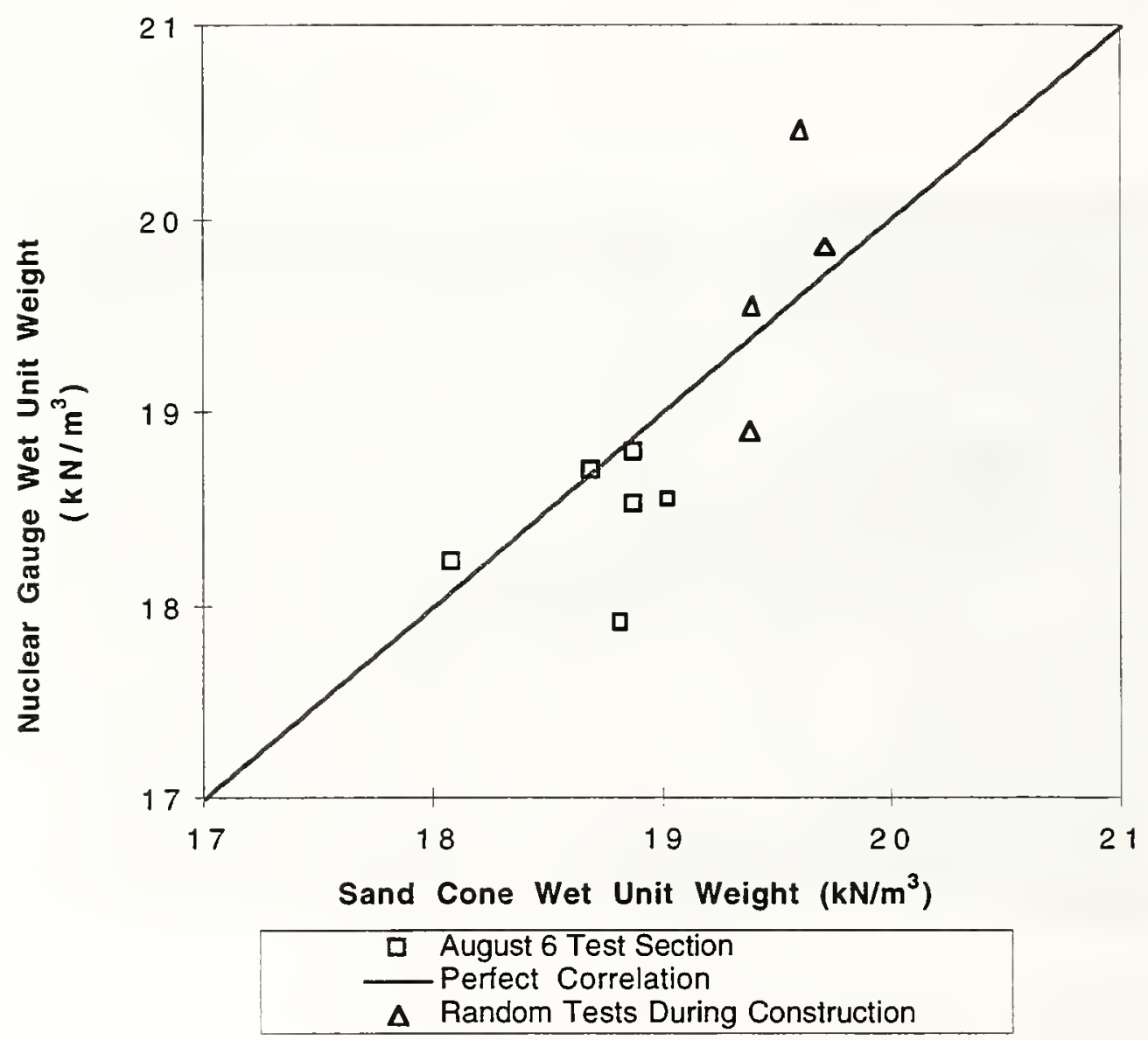

Figure 5.10. Field Measurements of Wet Unit Weight of Auburn WFS. 


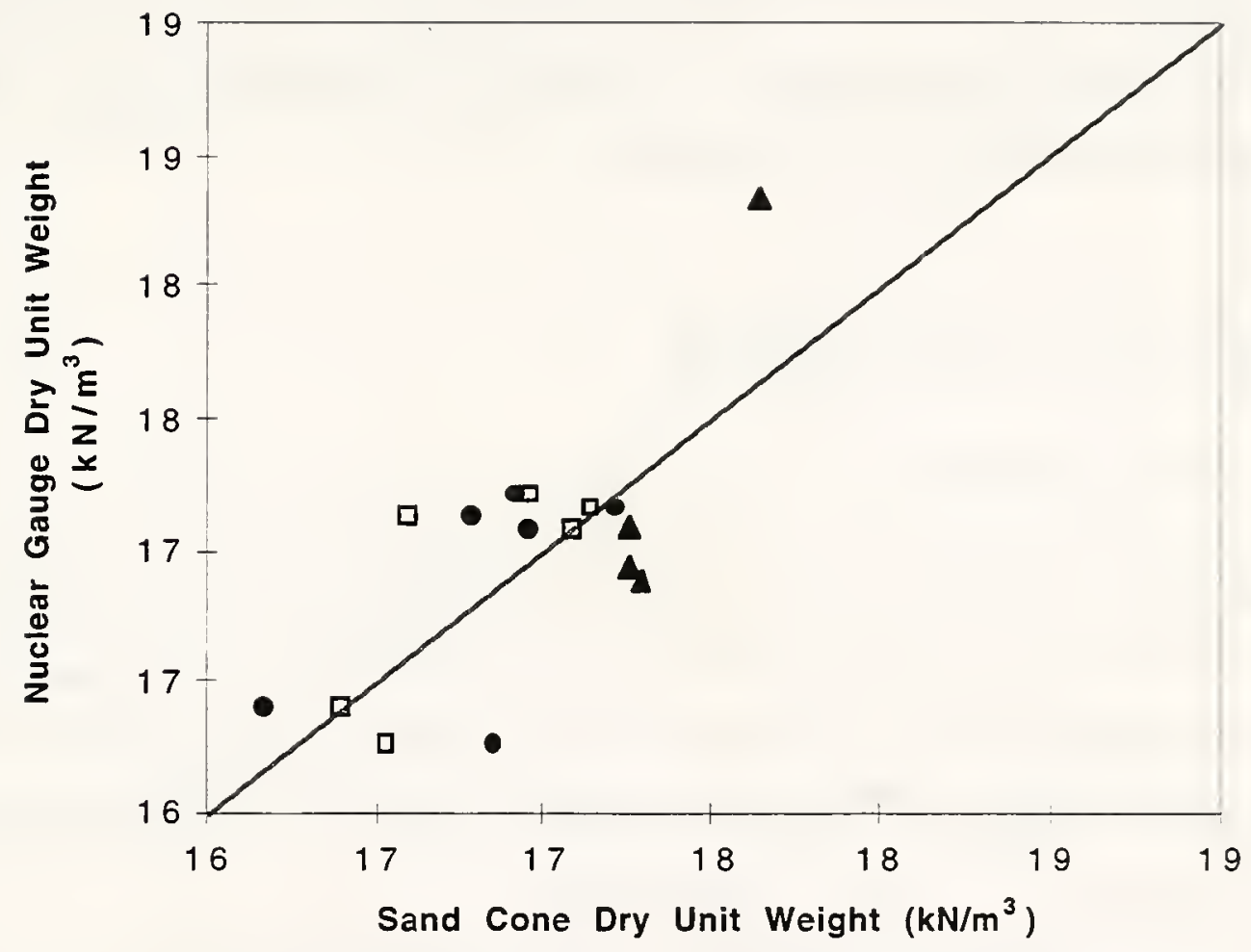

- Aug. 6 Test Pad, SC with Speedy w\%

- Aug. 6 Test Pad, SC with Oven w\% Perfect Correlation

- Random Tests with Speedy w\%

Figure 5.11. Field Measurements of Dry Unit Weight of Auburn WFS. 
values. Figure 5.12 presents a comparison of moisture contents obtained using the nuclear density gauge and SMM with oven-dry values. The dashed lines represent a 5 percentage point offset from perfect correlation. Although moisture contents obtained using the nuclear density gauge and SMM were generally lower than those obtained by oven drying, the SMM was more reliable for the measurement of WFS moisture contents for this project. Interestingly, the nuclear gauge did not give accurate wet unit weight measurements for WFS, but the dry unit weight measurements match reasonably well. A correction for nuclear density gauge moisture contents may be necessary for future WFS projects.

\subsection{EMBANKMENT DEFORMATION}

\subsubsection{Vertical Movement}

Horizontal inclinometers and settlement plates were used to measure vertical deformation of the WFS embankment. The intent for the horizontal inclinometers was to compare absolute elevations of the tubes to measure deformation of the embankment and foundation soils. Embankment deformation was also estimated by comparing the elevations of settlement plates over time. Both of these methods depend on precise surveying data, which was difficult to achieve for this project.

\subsubsection{Horizontal Inclinometers}

The installation procedure for the bottom horizontal inclinometer was as follows:

1. Approximately $1.8 \mathrm{~m}$ of WFS was placed and compacted on the site.

2. Using a backhoe, a trench was dug in the WFS to the foundation soil elevation.

3. The trench sides were sloped at $2: 1(\mathrm{H}: \mathrm{V})$ to reduce arching effects after inclinometer installation.

4. The inclinometer tube was laid in the trench and backfilled by hand. The bottom tube was approximately $76 \mathrm{~m}$ long. The reading taken during data collection at a horizontal distance of $38 \mathrm{~m}$ is approximately at the center of the embankment. 


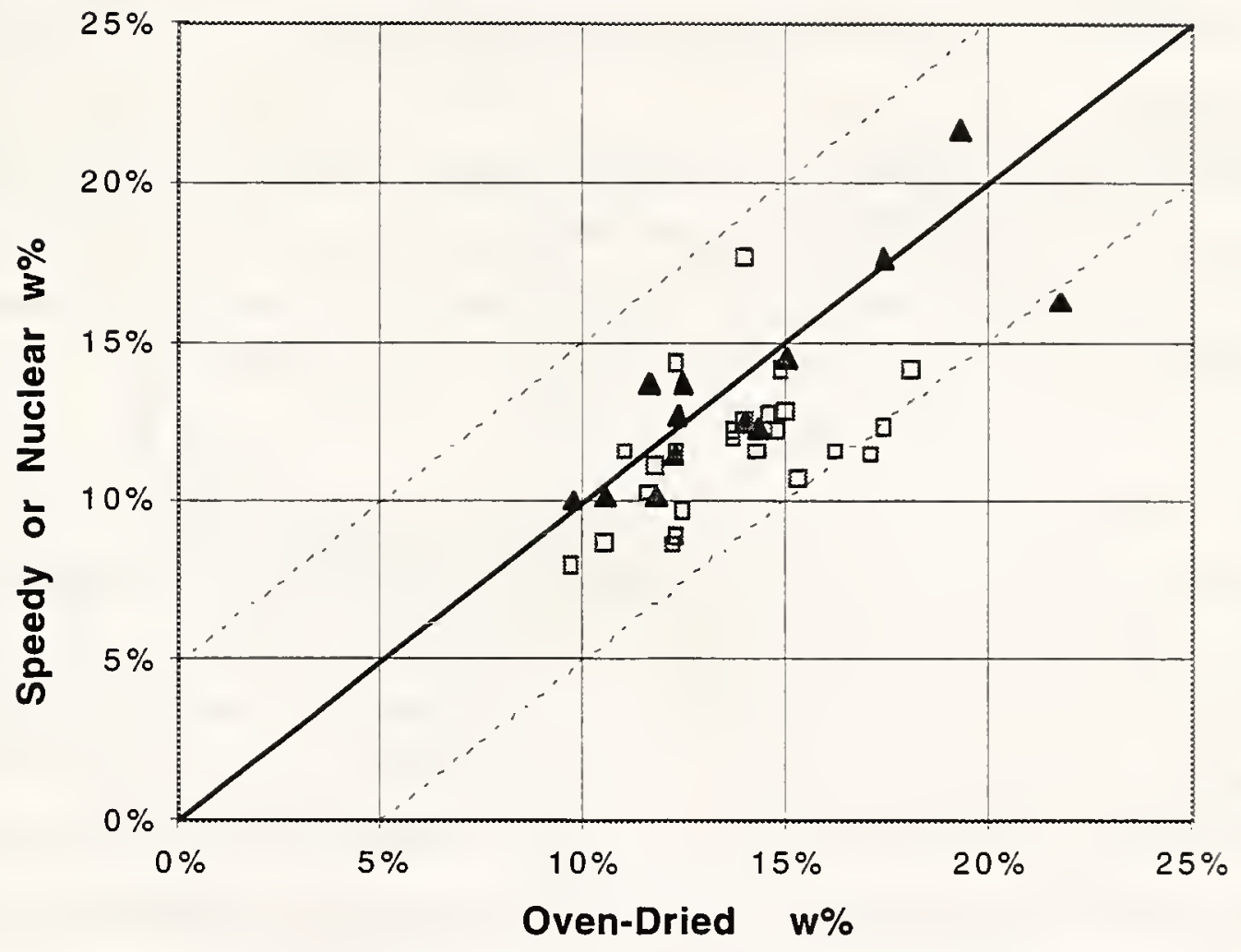

A 'Speedy' Moisture Content Perfect Correlation

- Nuclear Gauge Moisture Content

Figure 5.12. Field Measurements of Moisture Content of Auburn WFS. 
5. The first two $200 \mathrm{~mm}$ lifts of WFS were compacted over the inclinometer tube using a vibratory plate. The trench was then backfilled using a backhoe and compacted by a rubber-tire roller.

6. Both ends of the inclinometer were placed so that they would be accessible after construction was completed (approx. $39.6 \mathrm{~m}$ from centerline).

Inclinometer readings were taken at $2 \mathrm{~m}$ intervals, beginning at the east end with a position reading of $74 \mathrm{~m}$ (measured from the west end). The final reading at the west end $(0 \mathrm{~m})$ was taken with the probe approximately $0.3 \mathrm{~m}$ from the open end of the tube. The first reading of the bottom inclinometer was taken on July 29, 1996.

Figure 5.13 presents settlement of the bottom horizontal inclinometer relative to the July 29 , 1996, reading. The horizontal position (abscissa) is taken from the west end of the tube. A negative value indicates downward movement of the tube. The irregular pattern of settlement likely reflects variations in foundation soil stiffness and applied stress across the width of the embankment. The data suggest that the west end of the inclinometer pipe became clogged between March 13 and October 19, 1997. As a result, the instrument did not read properly between 0 and $20 \mathrm{~m}$ on October 19. Taking this error into account, settlement reached a maximum value of $45 \mathrm{~mm}$.

The top horizontal inclinometer was $42.6 \mathrm{~m}$ long and was placed $4.0 \mathrm{~m}$ below the crest elevation of the embankment. Figure 5.14 presents settlement vs. horizontal position for the top inclinometer. The centerline of the embankment is at a horizontal position of approximately $20 \mathrm{~m}$. The top inclinometer showed an initial settlement of $15 \mathrm{~mm}$ soon after installation and a total settlement of $25 \mathrm{~mm}$ after 21 months. The top inclinometer showed less settlement than the bottom inclinometer because it was installed after the majority of the WFS had been placed in the embankment.

There are several sources of error associated with the horizontal inclinometer data, such as surveying and damage from construction operations. It is likely that the general settlement 


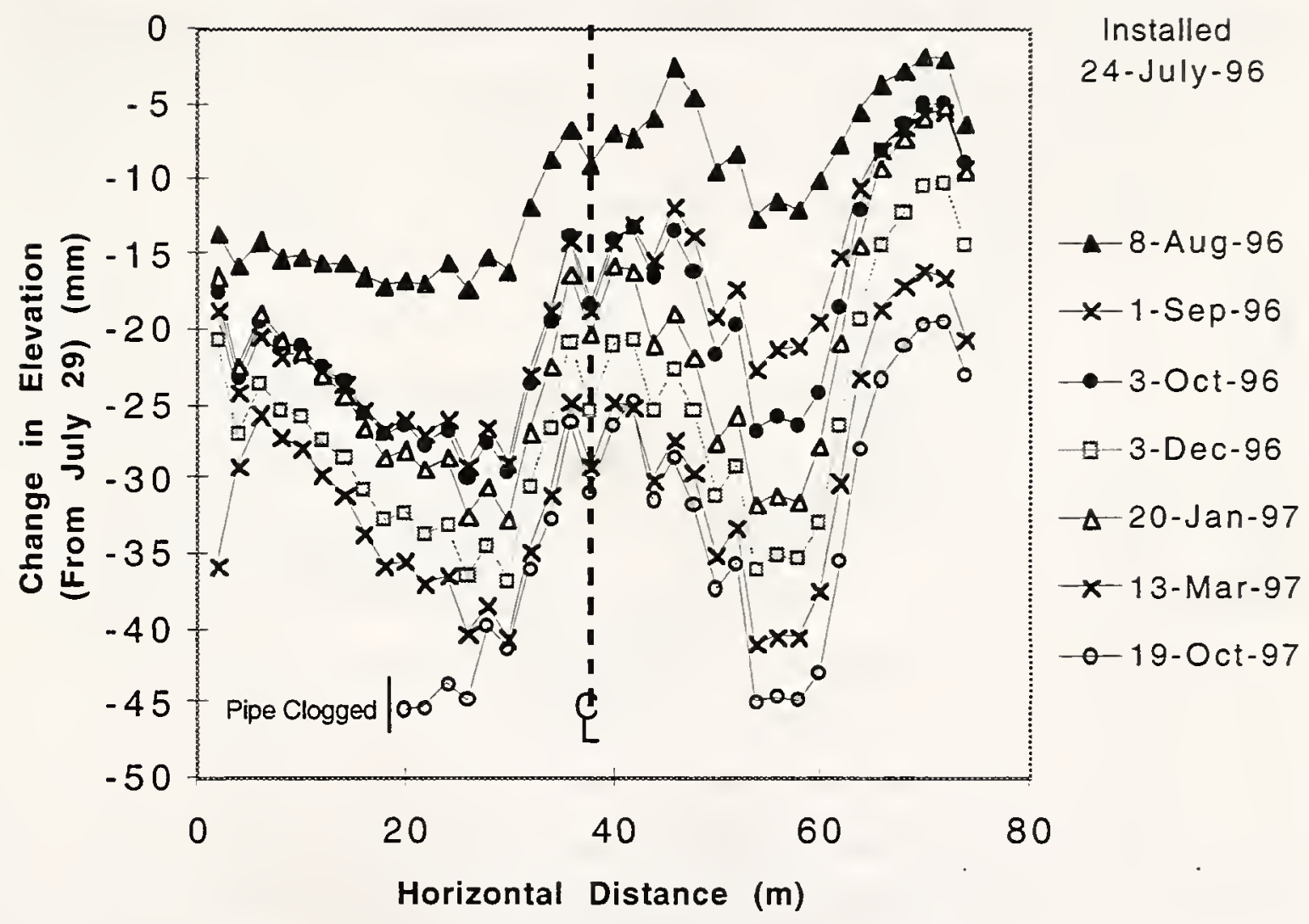

Figure 5.13. Settlement of Bottom Horizontal Inclinometer. 


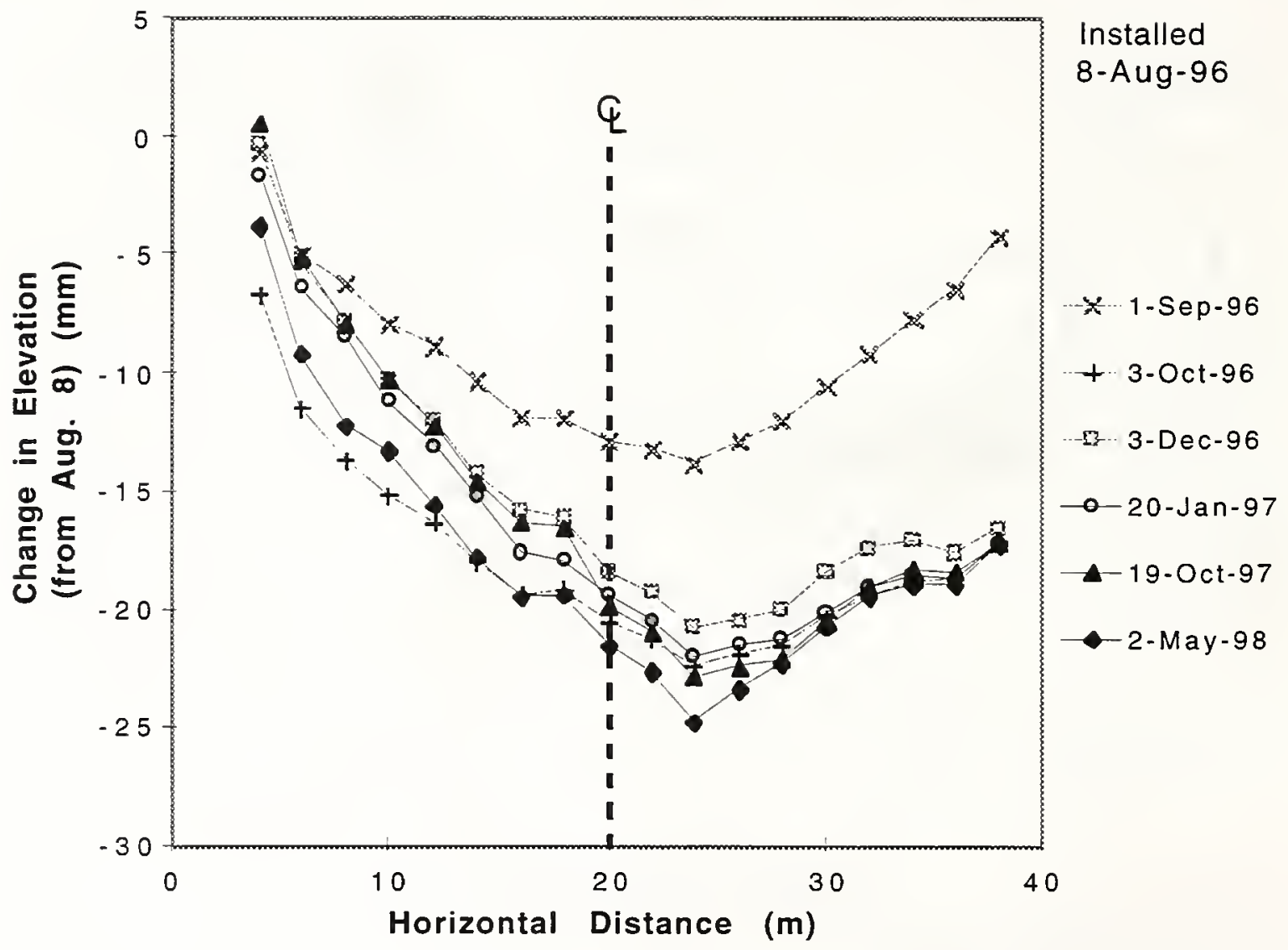

Figure 5.14. Settlement of Top Horizontal Inclinometer. 
profile for each inclinometer is correct, but a direct comparison of the top and bottom inclinometers elevations to indicate WFS compression may be inaccurate.

\subsubsection{Settlement Plates}

Four sets of settlement plates ( 3 plates each) were installed in the embankment. Two of the sets, designated as WFS North and WFS South, measured the deformations in the WFS section. Additional sets were installed in the clay borrow and B-Borrow sections. The bottom plate in each set was placed on the foundation soils, the second plate was installed at the midheight of the embankment, and the third plate was installed near the top of the embankment. As construction proceeded, additional pipe sections were added to the settlement plate rods as necessary.

The following problems were encountered with respect to settlement plates:

1. The bottom settlement plate for the clay borrow was not installed with a friction sleeve.

2. There were several instances where the contractor added pipe to a settlement plate without notifying INDOT or Purdue personnel so that surveying could be completed beforehand. Thus, not only was settlement data lost, but the true distances to the plates were also no longer known. This problem was largely avoided after August 15, 1996 , when most of the embankment was completed. However, several of the settlement pipes were extended by the contractor in December without Purdue personnel present. Thus, only the clay borrow and the WFS north settlement plates have continuous data from August 15, 1996, to the end of the project.

3. Several of the settlement plates were damaged by construction equipment after August 15, 1996. In some cases, the pipes could be repaired. However, the settlement plates for the clay borrow and WFS South were broken and not repaired.

Figure 5.15 defines distances L1, L2, and L3 between settlement plates. Changes in these values indicate compression between the settlement plates. Figures 5.16 through 5.18 present the settlement plate data. Survey elevations which were clearly in error are not shown. Chart (a) of each figure shows the change in elevation for each plate vs. time, relative to its position. 


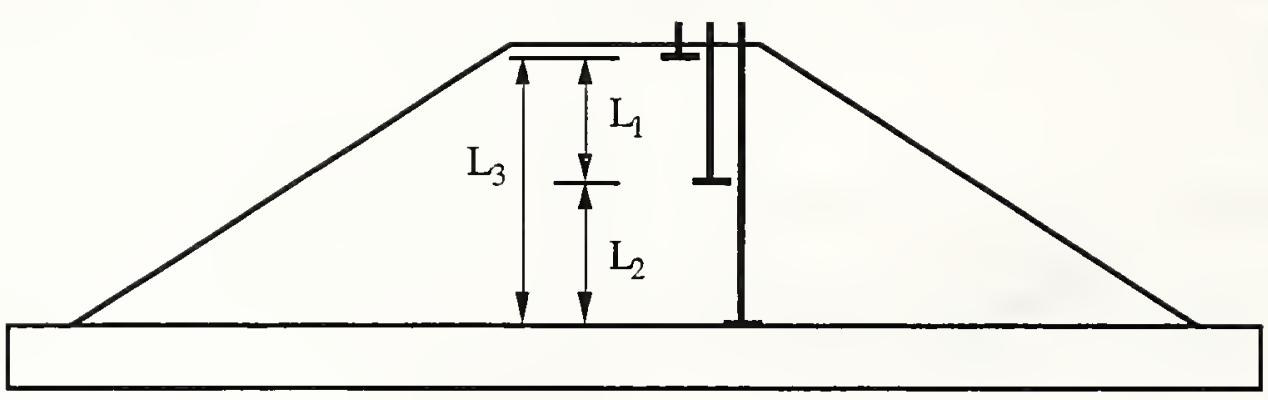

Figure 5.15. Definition of Settlement Plate Elevation Differences. 


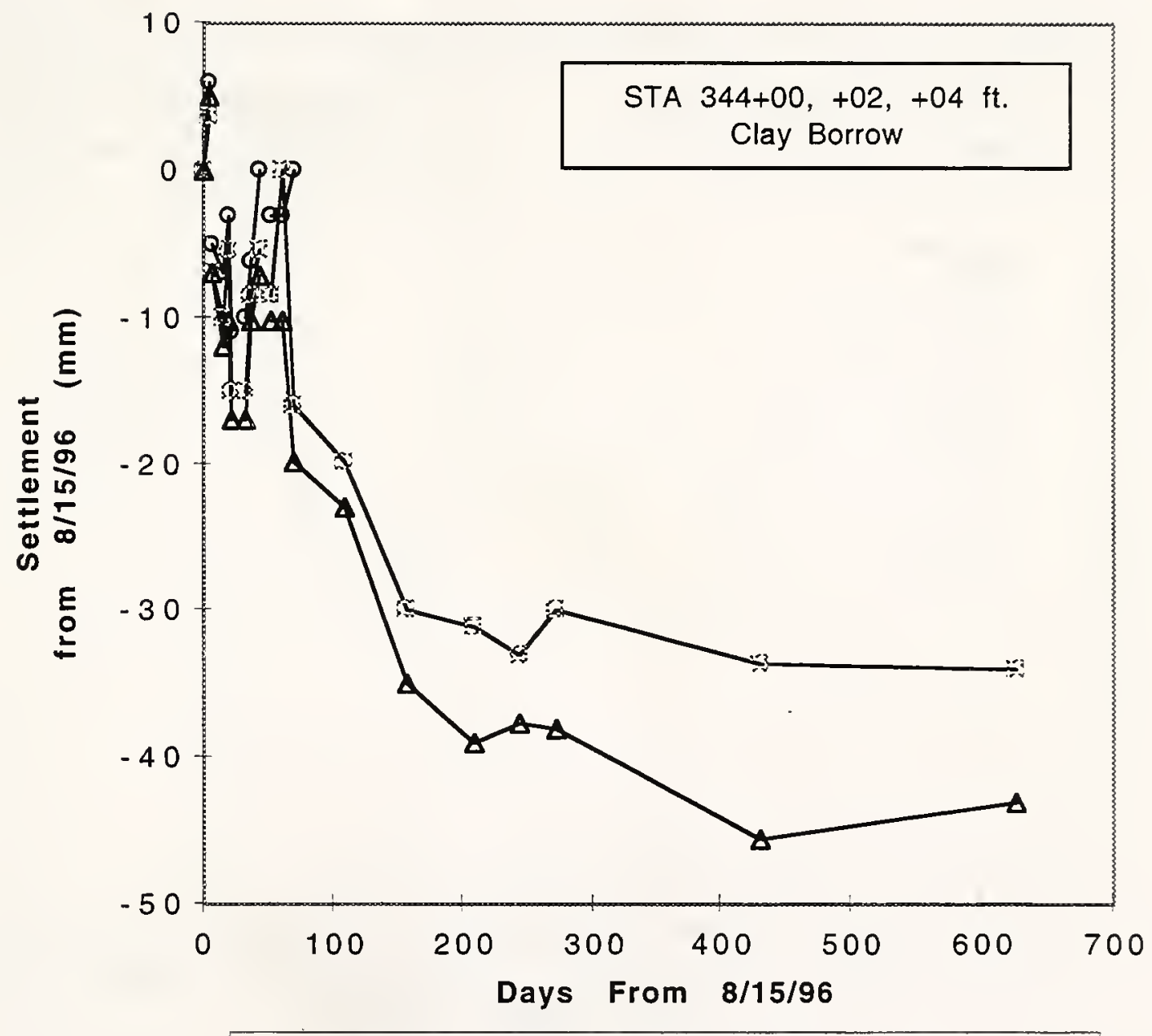

- Elev. $268.2 \mathrm{~m}-5-$ Elev. $272.8 \mathrm{~m} \triangle$ Elev. $277.3 \mathrm{~m}$

Figure 5.16(a). Settlement of Clay Borrow Settlement Plates. 


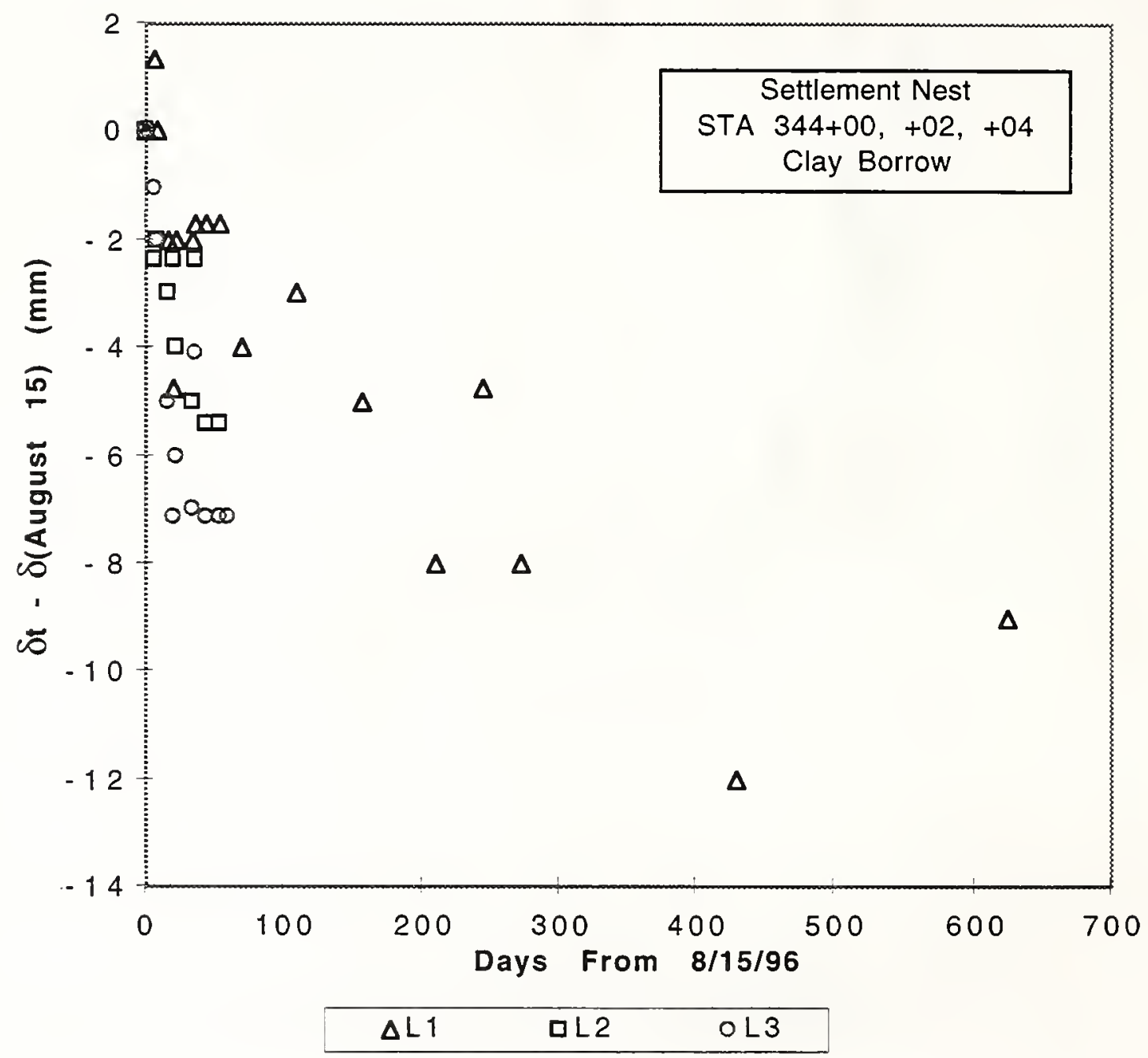

Figure 5.16(b). Elevation Differences for Clay Borrow Settlement Plates. 


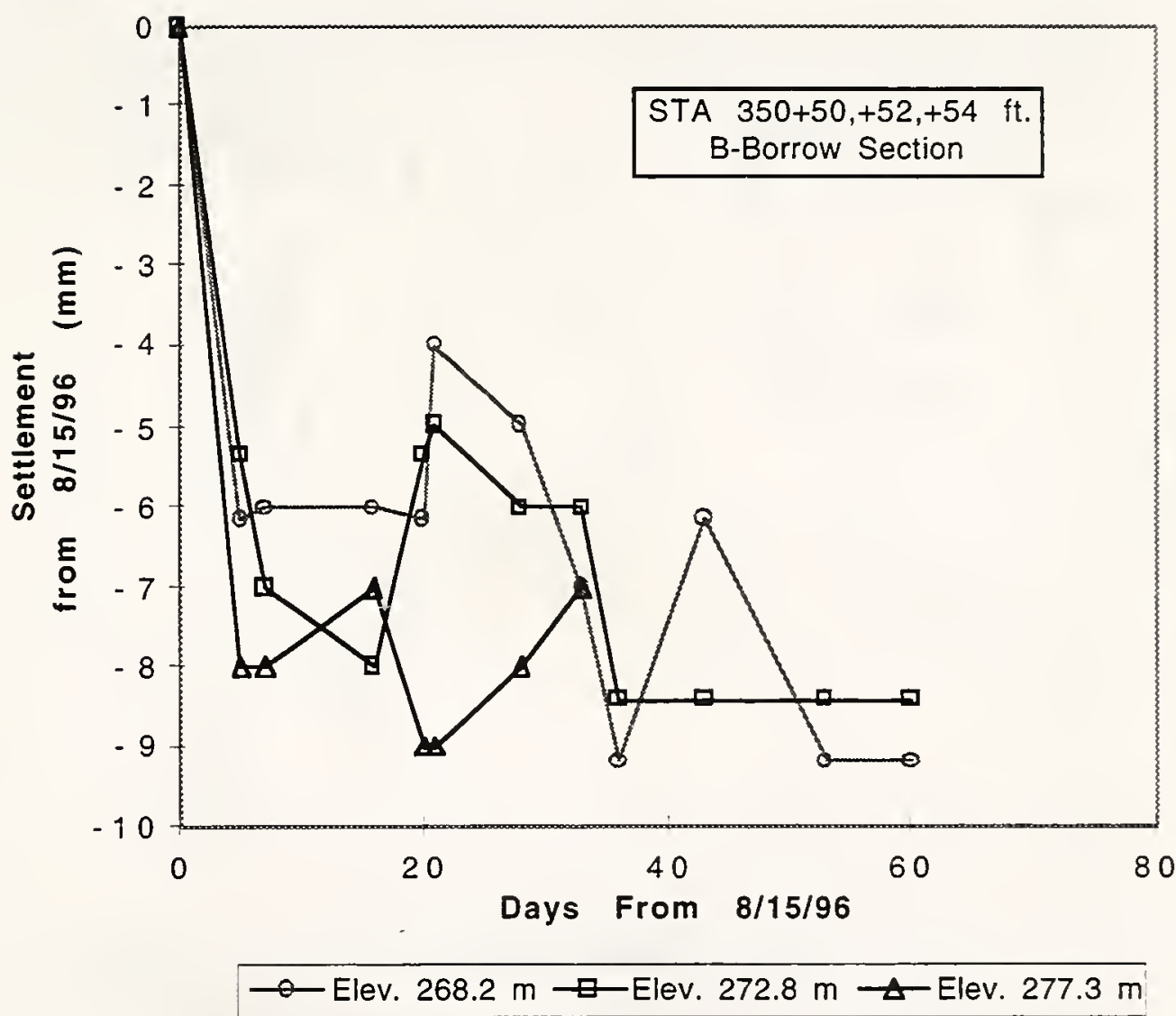

Figure 5.17(a). Settlement of B-Borrow Settlement Plates. 


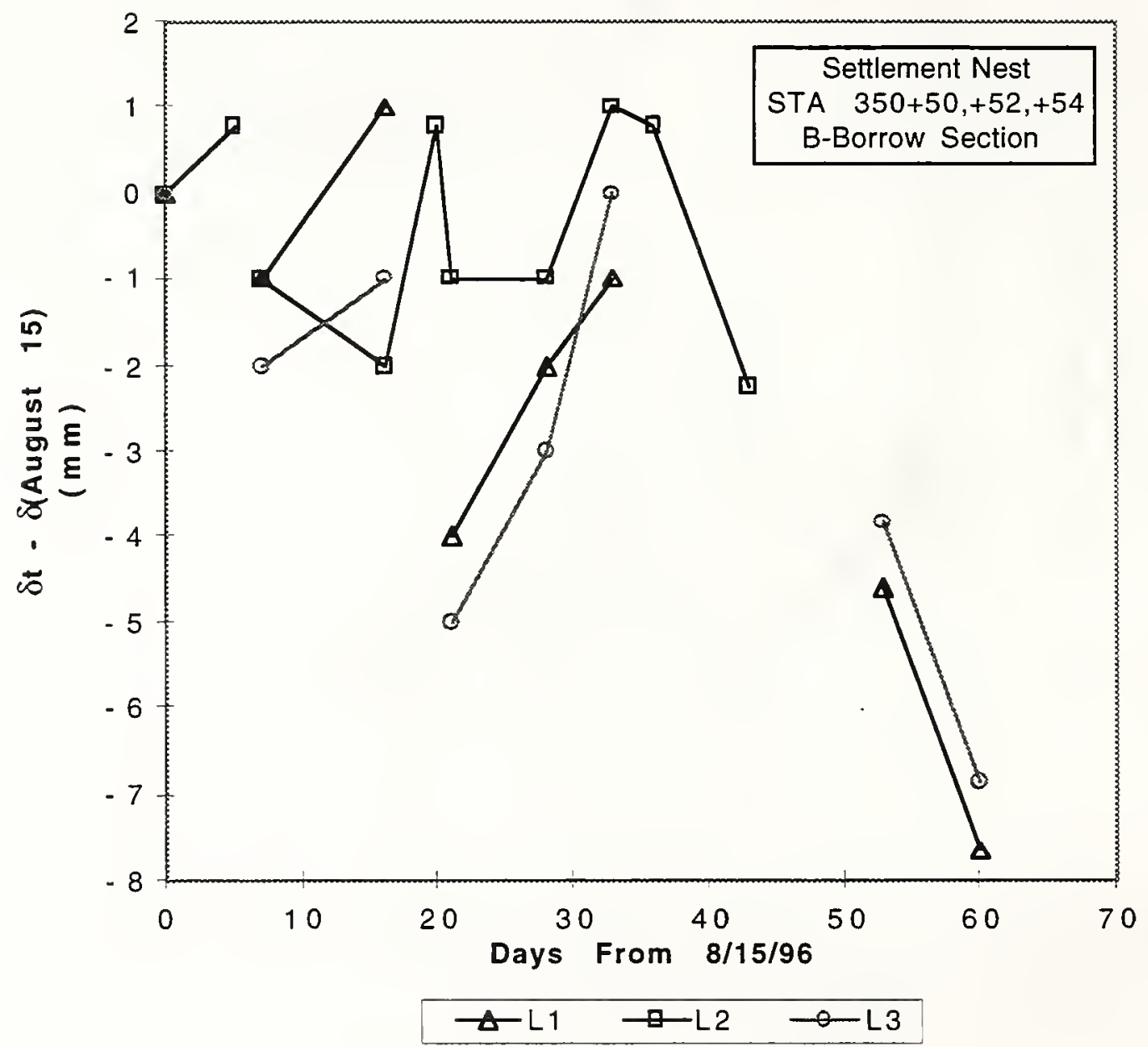

Figure 5.17(b). Elevation Differences for B-Borrow Settlement Plates. 


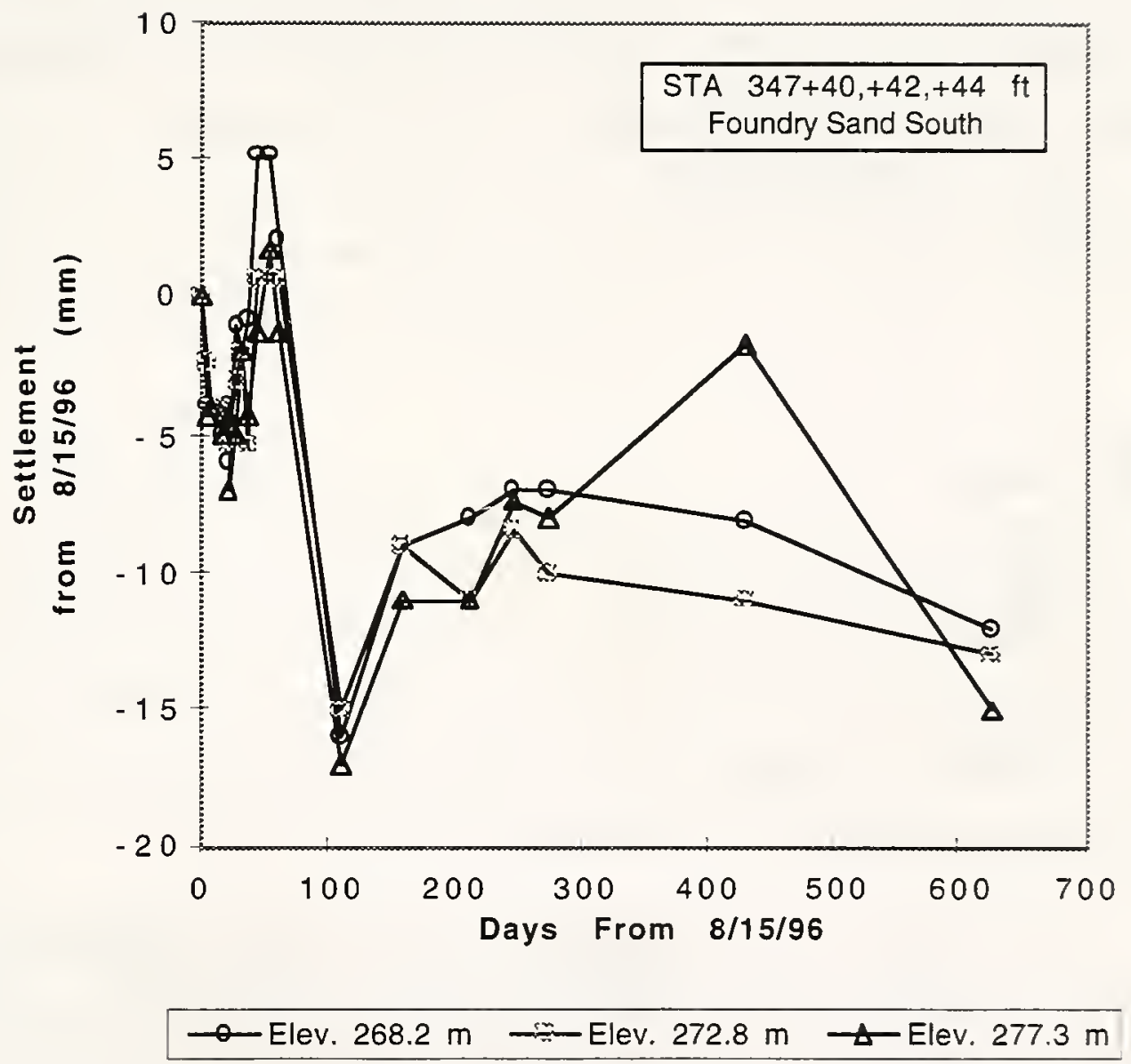

Figure 5.18(a). Settlement of WFS South Settlement Plates. 


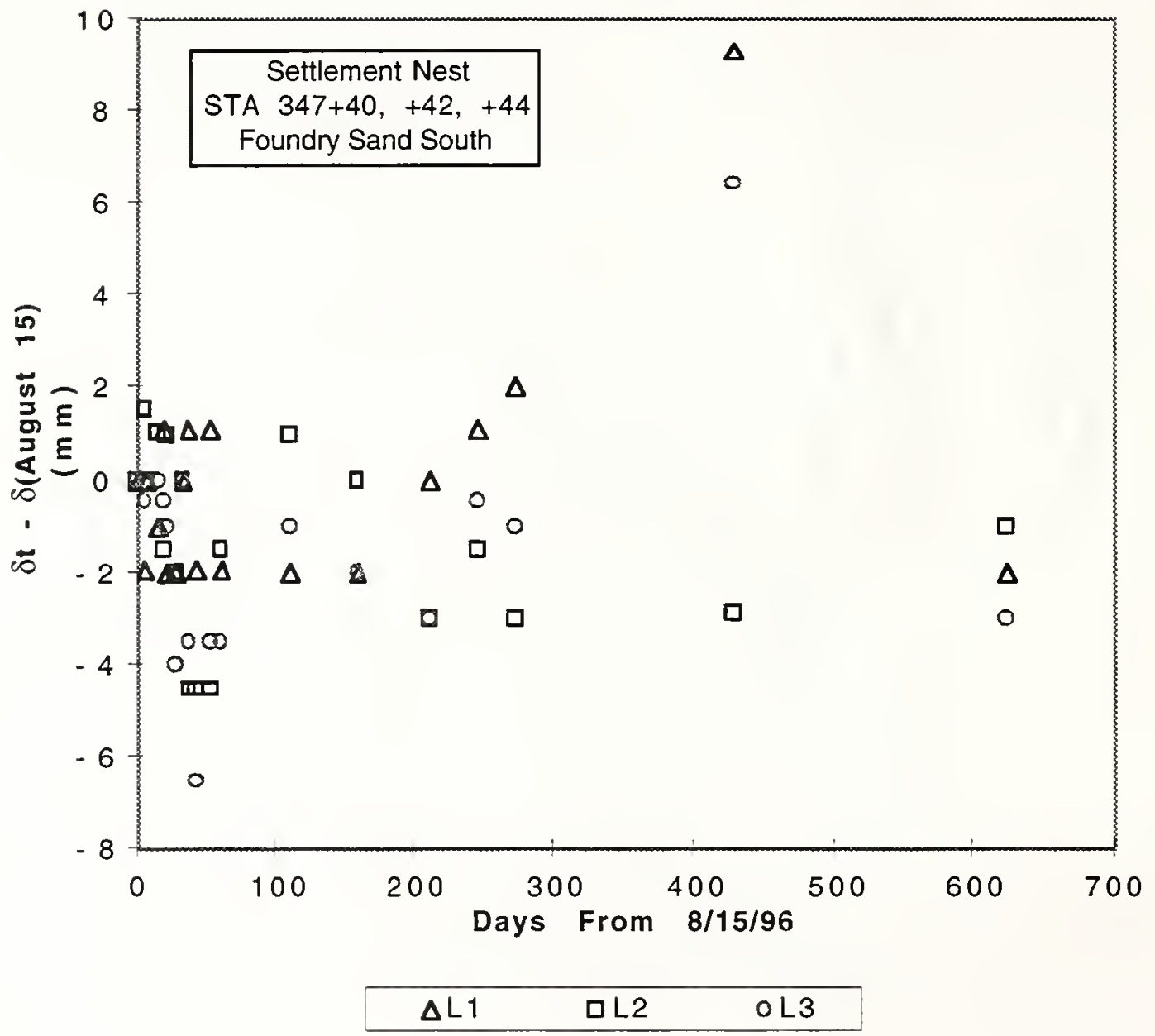

Figure 5.18(b). Elevation Differences for WFS South Settlement Plates. 
on August 15, 1996. Chart (b) of each figure gives L1, L2, and L3 vs. time from August 15, 1996. The data from the WFS North set did not follow a clear pattem and is not presented. Surveying errors and damage during construction are likely responsible the erratic behavior of the settlement plate data. The clay borrow (Figure 5.16) shows a maximum settlement of approximately $45 \mathrm{~mm}$ and a maximum compression of $12 \mathrm{~mm}$. For comparison, the WFS The B-Borrow (Figure 5.17) showed $8.9 \mathrm{~mm}$ of settlement in the foundation plate before damage and $6.4 \mathrm{~mm}$ of compression between the top and bottom plates before damage. South data (Figure 5.18) indicates $15.2 \mathrm{~mm}$ of foundation settlement and a maximum of $7 \mathrm{~mm}$ compression between the top and bottom plates. These data suggest that compression of the WFS was comparable to B-Borrow for this project.

\subsubsection{Lateral Movement}

\subsubsection{Installation of Vertical Inclinometers}

Vertical inclinometers were installed prior to embankment construction in order to measure WFS deformation during construction. As construction proceeded, the contractor was instructed to compact WFS around the inclinometer tubes using a small vibratory plate. As the embankment reached the top of the inclinometer tubes, new lengths of tubing were added. Weekly vertical inclinometer readings were taken during the construction of the embankment.

\subsubsection{Difficulties with Vertical Inclinometers}

Construction vehicles damaged the vertical inclinometers on several occasions. On July 22, the east vertical inclinometer was repaired after it was broken off by a truck. The west vertical inclinometer was damaged by a bulldozer on August 22. Finally, the vertical inclinometer tubes were disturbed as cover soil was placed on the embankment. As a result, the vertical inclinometer data does not provide a useful assessment of lateral embankment deformation during construction. Consequently, the data recorded during construction is not presented.

\subsubsection{Lateral Movements after Construction}

Figure 5.19 presents lateral displacements of the east vertical inclinometer taken with respect to the measurements of August 8, 1996, when WFS placement was nearly completed. An approximate soil profile is shown adjacent to the data. The majority of the movement is away 


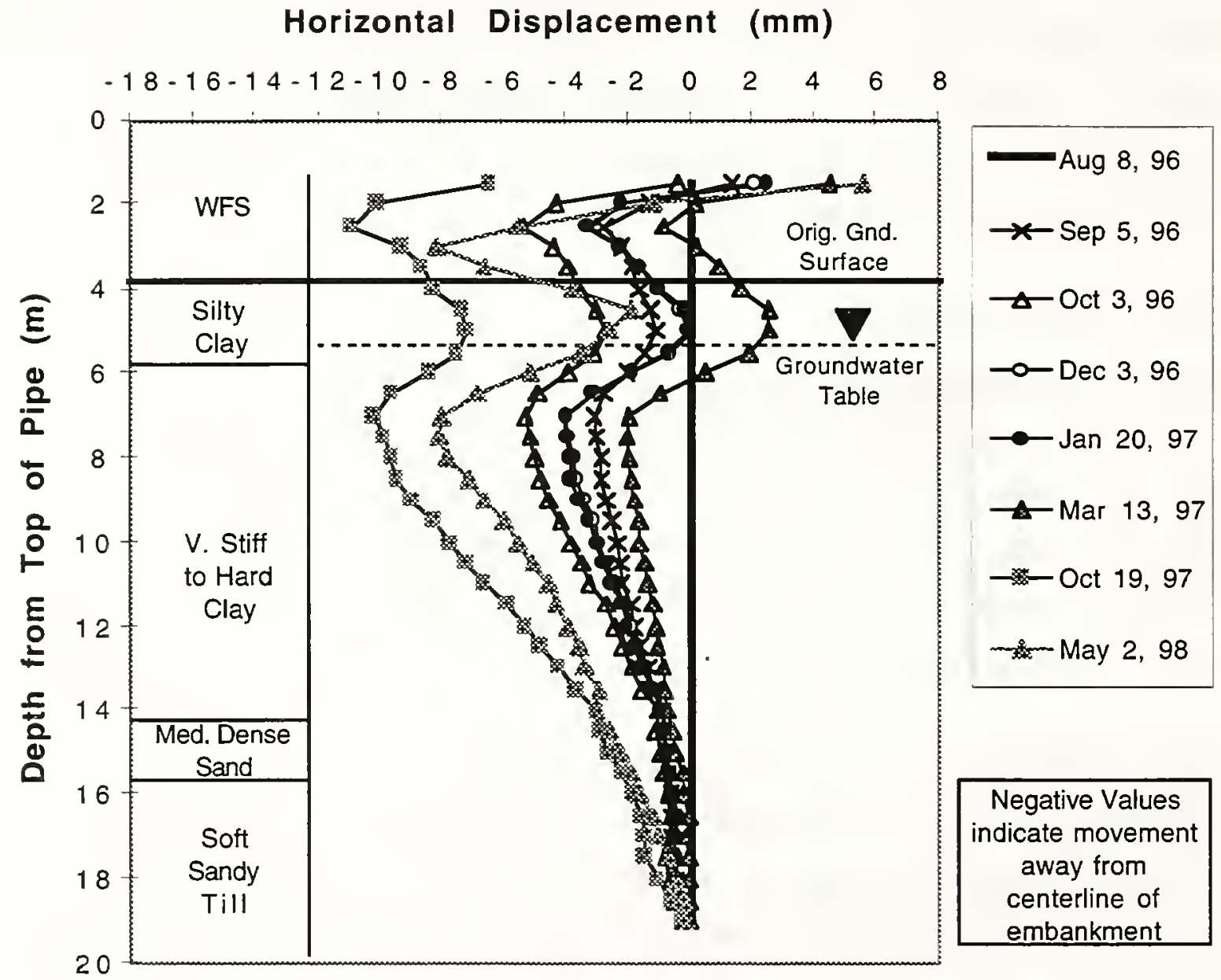

Figure 5.19. Horizontal Displacements of East Vertical Inclinometer. 
from the centerline of the embankment, as expected. Figure 5.20 presents the west vertical inclinometer displacements with respect to measurements taken on August 8, 1996. For both figures, negative values indicate movement away from the centerline of the embankment.

The east vertical inclinometer experienced lateral displacements as large as $5 \mathrm{~mm}$ between August 8, 1996, and March 13, 1997. The maximum displacement increased to $11 \mathrm{~mm}$ on October 19, 1997. Profiles for the west vertical inclinometer indicate lateral displacements of 3 to $4 \mathrm{~mm}$ up to March 13, 1997, with a small increase in October, 1997. In June, 1998, significant horizontal movement was recorded in the WFS section. Repeated measurements have shown the indicated movement is not due to instrument error. Continued monitoring may be warranted for the west side of the embankment.

\subsubsection{Sondex Measurements}

During installation of the horizontal inclinometers, metal plates were placed around the inclinometer tubes at $6.1 \mathrm{~m}$ intervals to measure lateral deformations within the embankment. A Sondex probe was inserted into the inclinometer casing to make these measurements. This probe uses an electric field to locate the position of each metal plate. In concept, if the soil moves laterally within the embankment, the metal plates will slide along the inclinometer tubing with the soil. Then, by comparing the position of the plates with the baseline reading, lateral movement can be estimated.

Data was gathered for the Sondex system three times, over a period of 2 months, after the WFS was placed. The measurements showed no movement of the metal plates. These measurements are considered accurate to approximately $30 \mathrm{~mm}$.

\subsection{IN SITU HYDRAULIC CONDUCTIVITY TESTING}

In order to verify the laboratory hydraulic conductivity measurements for compacted Auburn WFS, a sealed double-ring infiltrometer (SDRI) test was performed in the field (Figure 5.21). 


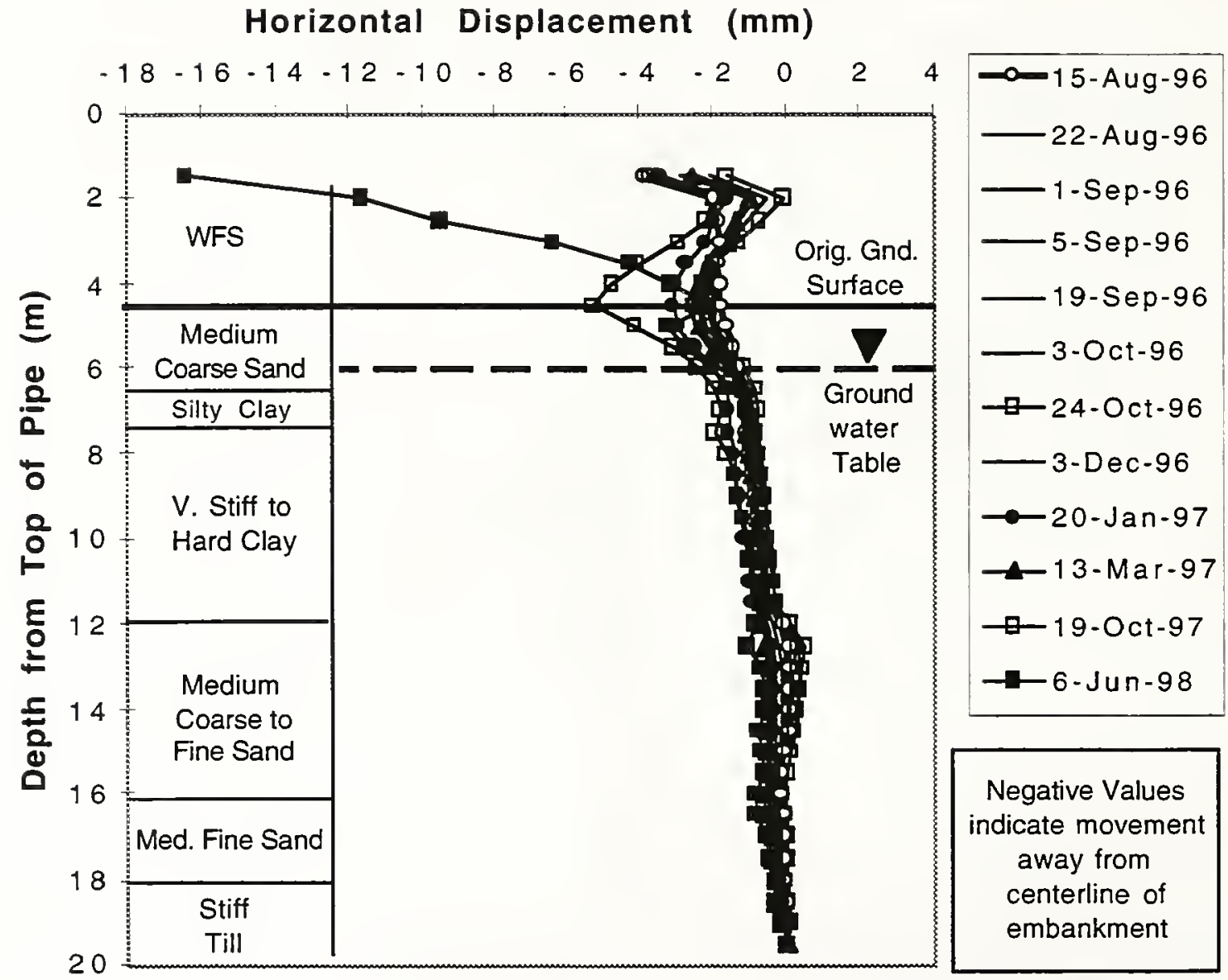

Figure 5.20. Horizontal Displacements of West Vertical Inclinometer. 


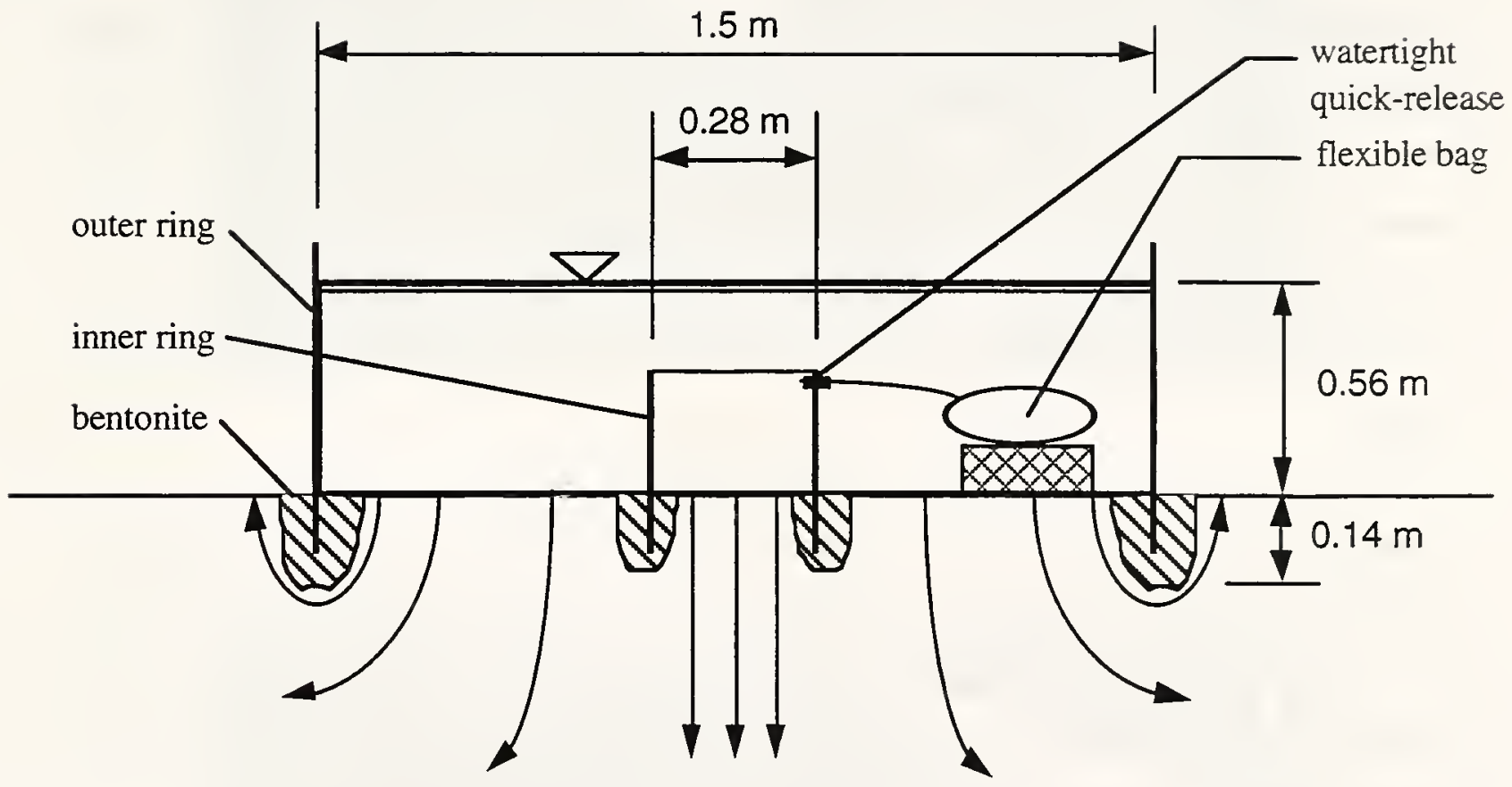

Figure 5.21. SDRI Test of WFS. 
The SDRI eliminates evaporation losses during testing and produces approximately onedimensional flow through the inner ring (Trautwein and Boutwell 1994).

Prior to SDRI installation, the hardened WFS surface material was loosened to a depth of approximately $50 \mathrm{~mm}$. To begin the test, the outer ring was filled with water and the plastic bag was filled with water and weighed. It was attached to the inner ring by a quick-release connection. The bag was then weighed periodically to determine the volumetric flow rate. Tensiometers were not installed under the SDRI due to the hardness of the compacted WFS. The test was interrupted after 2 weeks to check the WFS surface inside the ring. After loosening the WFS surface within the outer ring, a second test trial was initiated. Construction operations required removal of the SDRI after 18 days of measurements. The data from the first testing period was ignored in this analysis due to the hardened condition of the WFS surface.

A photograph of the SDRI during installation is shown in Figure 5.22(a). A yardstick is shown inside the SDRI for scale. The 3-liter plastic inflow bag is resting on top of the inner ring. Figure 5.22(b) shows the SDRI during testing. In this photo, the inner ring can be seen under the water. The plastic bag is tied to a concrete block to keep it submerged, assuring that the total head inside of the inner ring is identical to that inside the outer ring.

Figure 5.23 presents volumetric flow rate versus time for the SDRI test. Prior to termination of the test, the flow rate approached a steady value of $0.0078 \mathrm{~mL} / \mathrm{s}$. To calculate the position of the wetting front, it was assumed that the inflow water saturated a cylinder of WFS directly below the inner ring. The pore pressure at the wetting front was assumed to be zero. Thus, the hydraulic gradient was calculated as $\left(\mathrm{H}_{w}+\mathrm{L}\right) / \mathrm{L}$, where $\mathrm{H}_{\mathrm{w}}=$ height of water in the outer ring and $\mathrm{L}=$ calculated depth of the wetting front.

Based on the WFS properties given in Figure 5.23, the initial porosity and initial degree of saturation were 0.32 and $57 \%$, respectively. The total inflow included $12,190 \mathrm{~mL}$ from bag readings and 3.5 days of saturation prior to the first reading at an assumed flow rate of 0.010 


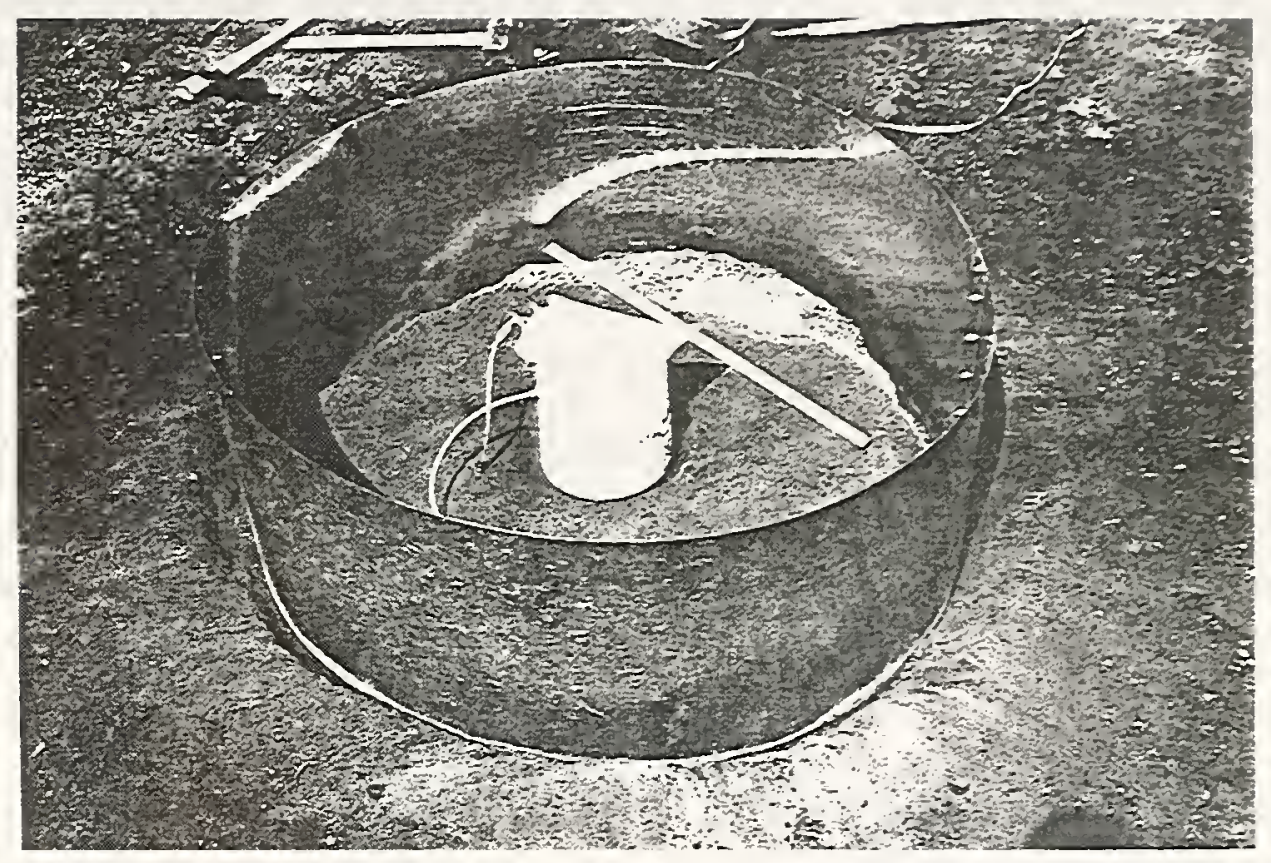

Figure 5.22(a). Installation of SDRI.

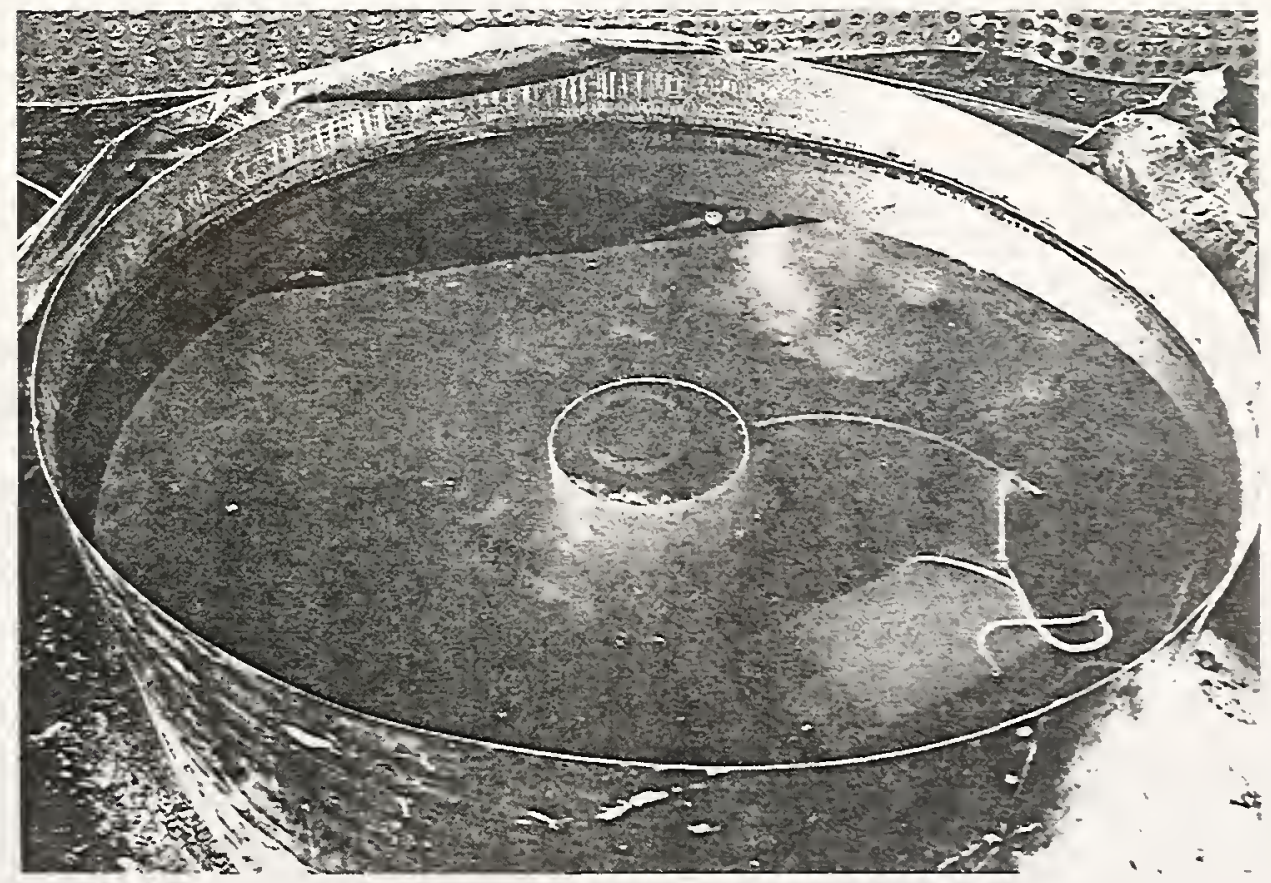

Figure 5.22(b). SDRI Test. 


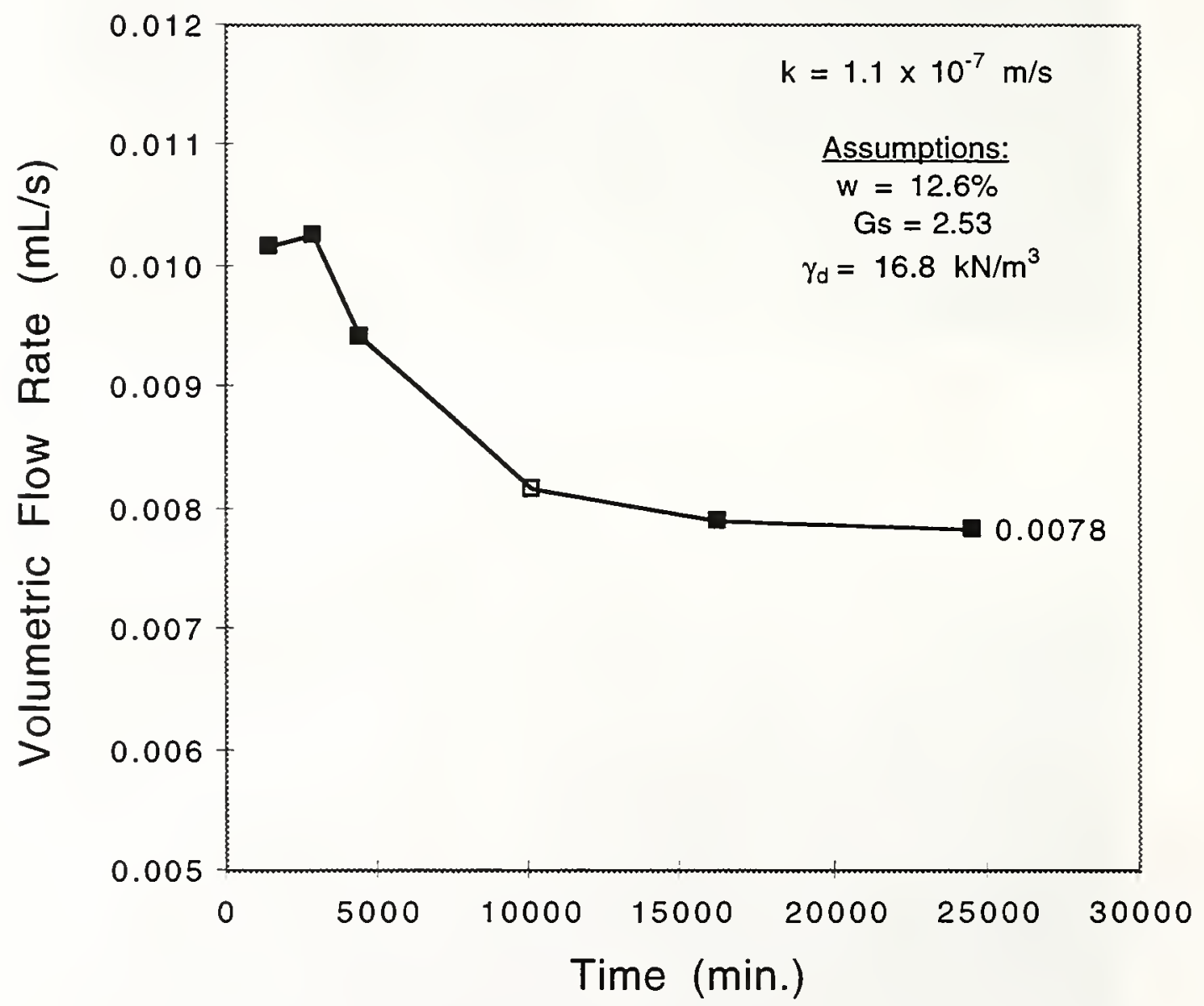

Figure 5.23. Volumetric Flow Rate vs. Time for SDRI. 
$\mathrm{mL} / \mathrm{s}$. Knowing the total volume of inflow water $(15,210 \mathrm{~mL})$ and the inner ring area $(0.0616$ $\mathrm{m}^{2}$ ), the depth of the wetting front is calculated as $2.34 \mathrm{~m}$. The height of water in the outer ring remained nearly constant throughout the test at $0.475 \mathrm{~m}$. Thus, the hydraulic gradient at the end of the test was 1.20 and the hydraulic conductivity for the compacted WFS is estimated as $1.1 \times 10^{-7} \mathrm{~m} / \mathrm{s}$. These results are consistent with field observations of low hydraulic conductivity made for a similar WFS embankment project in Wisconsin (Lovejoy et al. 1996). In addition, the estimated hydraulic conductivity value falls within the range of laboratory testing results presented in Table 4.1. An upper bound to the estimate of hydraulic conductivity can be calculated using a unit hydraulic gradient, which gives a value of $1.3 \times 10^{-7}$ $\mathrm{m} / \mathrm{s}$.

It should be noted no movements of the inner ring were measured to obtain a swell correction for this test. It was expected that this correction would be minimal because the CBR swell test showed negligible swelling for weathered WFS samples. The SDRI test indicates that the bentonite and other fines reduce the hydraulic conductivity of compacted Auburn WFS from that expected of a sandy material, as the term waste foundry "sand" implies. Compacted Auburn WFS is thus not considered a freely draining material.

\subsection{TOTAL STRESS MEASUREMENTS}

Two total pressure cells measured the stress imposed on the foundation soils under the centerline and shoulder ( $7 \mathrm{~m}$ east of centerline) of the embankment. Figure 5.24 presents vertical total stress vs. time for both cells. The final difference in stress for the pressure cells (36 $\mathrm{kPa}$ ) may be due to the effects of soil arching and/or the different locations of the cells underneath the embankment. Using the average measured total stress, the final embankment height, and an average moisture content of $12.6 \%$, a dry unit weight of $17.4 \mathrm{kN} / \mathrm{m}^{3}$ is calculated for the WFS. This estimate is in good agreement with the field unit weight values presented in Figure 5.8. 
$\mathrm{mL} / \mathrm{s}$. Knowing the total volume of inflow water $(15,210 \mathrm{~mL})$ and the inner ring area $(0.0616$ $\mathrm{m}^{2}$ ), the depth of the wetting front is calculated as $2.34 \mathrm{~m}$. The height of water in the outer ring remained nearly constant throughout the test at $0.475 \mathrm{~m}$. Thus, the hydraulic gradient at the end of the test was 1.20 and the hydraulic conductivity for the compacted WFS is estimated as $1.1 \times 10^{-7} \mathrm{~m} / \mathrm{s}$. These results are consistent with field observations of low hydraulic conductivity made for a similar WFS embankment project in Wisconsin (Lovejoy et al. 1996). In addition, the estimated hydraulic conductivity value falls within the range of laboratory testing results presented in Table 4.1. An upper bound to the estimate of hydraulic conductivity can be calculated using a unit hydraulic gradient, which gives a value of $1.3 \times 10^{-7}$ $\mathrm{m} / \mathrm{s}$.

It should be noted no movements of the inner ring were measured to obtain a swell correction for this test. It was expected that this correction would be minimal because the CBR swell test showed negligible swelling for weathered WFS samples. The SDRI test indicates that the bentonite and other fines reduce the hydraulic conductivity of compacted Auburn WFS from that expected of a sandy material, as the term waste foundry "sand" implies. Compacted Auburn WFS is thus not considered a freely draining material.

\subsection{TOTAL STRESS MEASUREMENTS}

Two total pressure cells measured the stress imposed on the foundation soils under the centerline and shoulder ( $7 \mathrm{~m}$ east of centerline) of the embankment. Figure 5.24 presents vertical total stress vs. time for both cells. The final difference in stress for the pressure cells ( $36 \mathrm{kPa}$ ) may be due to the effects of soil arching and/or the different locations of the cells underneath the embankment. Using the average measured total stress, the final embankment height, and an average moisture content of $12.6 \%$, a dry unit weight of $17.4 \mathrm{kN} / \mathrm{m}^{3}$ is calculated for the WFS. This estimate is in good agreement with the field unit weight values presented in Figure 5.8. 


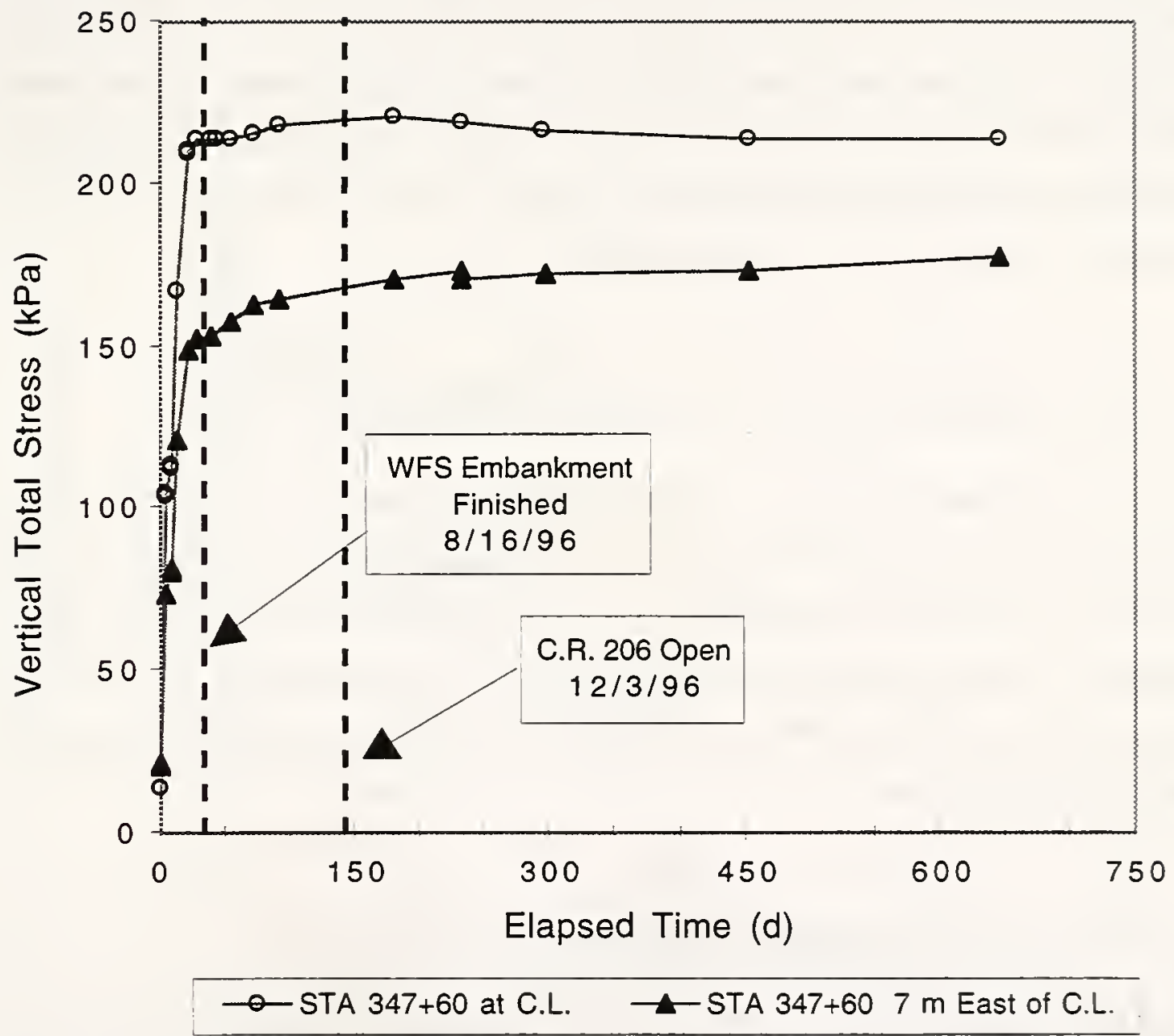

Figure 5.24. Total Stress at the Base of the WFS Embankment vs. Time. 


\subsection{SUBSURFACE PORE PRESSURE MEASUREMENTS}

Two hydraulic (constant volume) piezometers were installed at STA $348+52,7 \mathrm{~m}$ west of the centerline and STA $347+52,7 \mathrm{~m}$ east of the centerline. Both piezometers were installed at a depth of $6.1 \mathrm{~m}$ below the original ground surface. Figure 5.25 shows measured pore pressure vs. time for both piezometers. Consistent with the total stress measurements, pore pressures in the subsurface increased during WFS placement, peaked at approximately the same time as the pressure cells, and then returned to baseline readings.

\subsection{POST CONSTRUCTION STANDARD PENETRATION TESTING}

On March 4, 1997, three borings were drilled to evaluate the in situ properties of the WFS, Bborrow, and clay borrow embankments. Figure 5.26 presents the Standard Penetration Test (SPT) blow counts $(\mathrm{N})$ for each boring as a function of depth below the top of each embankment. Based on penetration resistance, the WFS section had relative densities which were comparable to the B-borrow section. In addition, the WFS had substantially higher blow counts than the clay borrow.

\subsection{DISCUSSION AND OBSERVATIONS}

The results of laboratory tests performed by Javed and Lovell (1994), as well as tests performed on the Auburn Foundry WFS, indicated that WFS should be generally acceptable as an embankment material. Ideally, such a material should have small intemal deformations; it should compact well with little dust control required; it should be freely draining; it should have good shear strength after compaction; it should require little added water to reach OMC; it should be homogeneous and free of foreign materials; and it should not be easily eroded. The results of field tests and observations suggest that the WFS used on this project met some, but not all, of these criterion. 


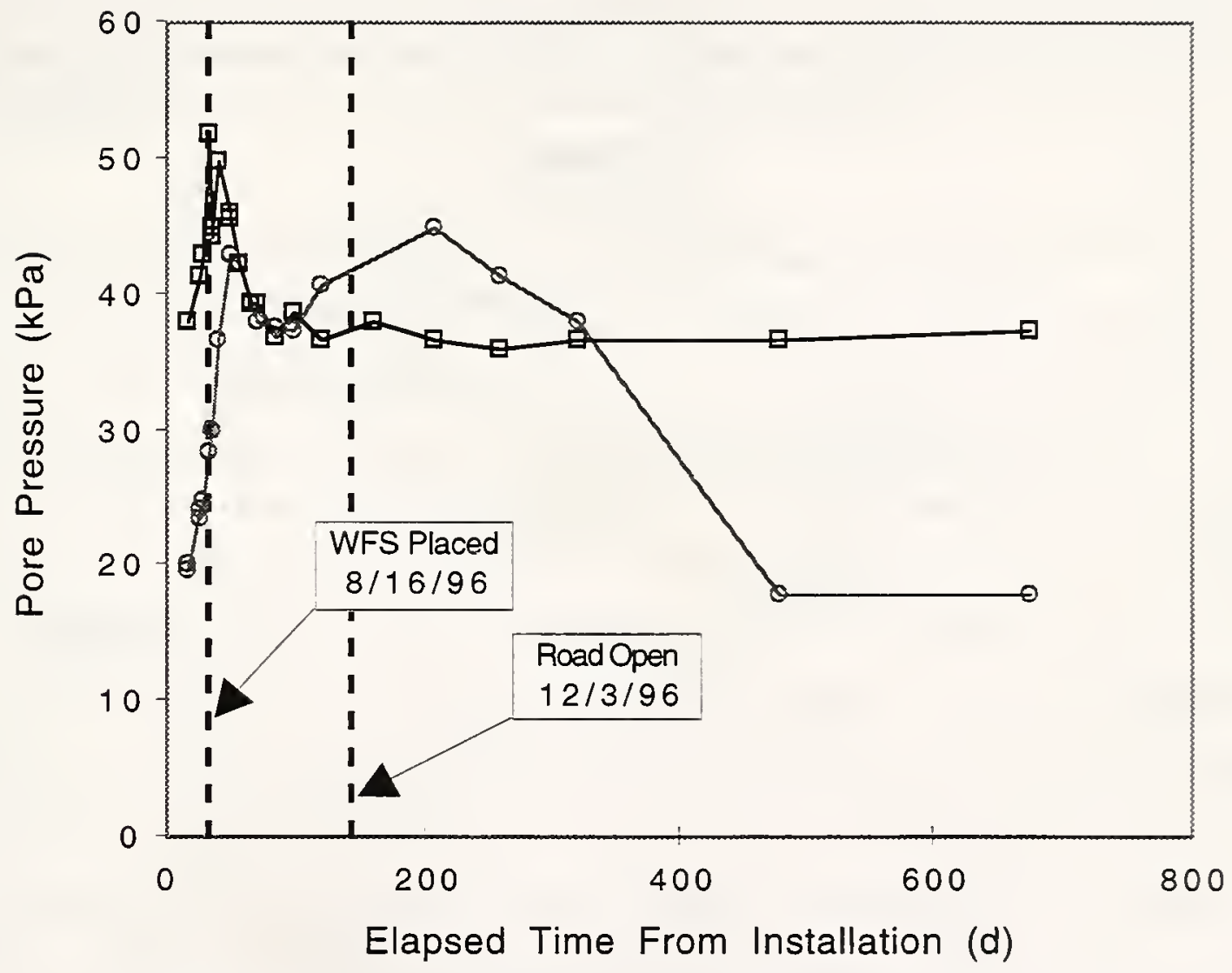

$\longrightarrow$ STA $347+507 \mathrm{~m}$ East of C.L. $\quad \longrightarrow$ STA $348+507 \mathrm{~m}$ West of C.L

Figure 5.25. Subsurface Pore Pressure vs. Time. 


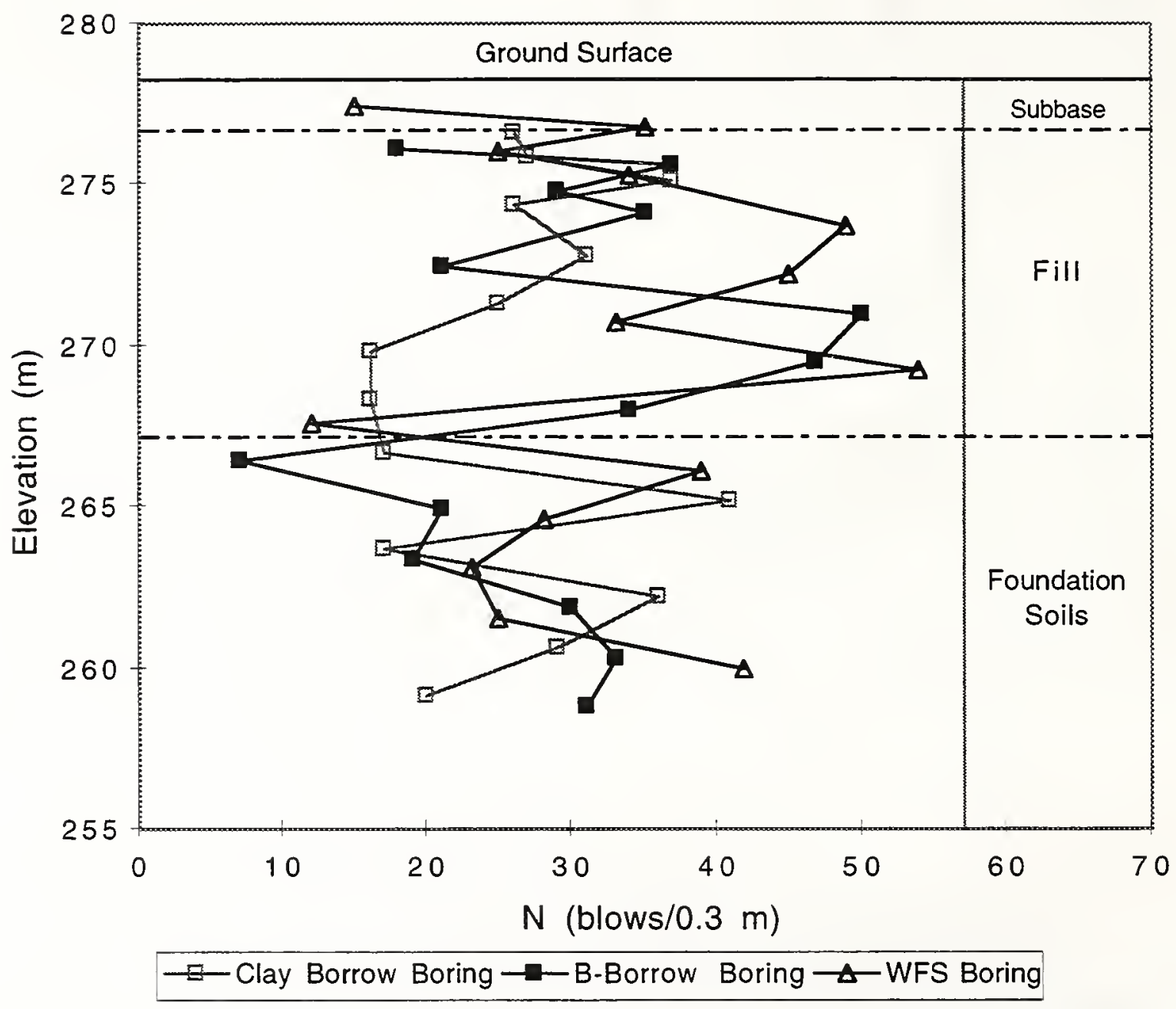

Figure 5.26. Standard Penetration Test Results. 
Construction of the WFS embankment proceeded with few problems. Initially, there was concern that foreign objects (e.g., slag, cores, castings, welding rods) in the WFS would damage construction equipment. Some of these objects were removed at the foundry monofill by a magnetic scraper bar dragged behind a tractor. Some of the larger objects were removed by hand in the early stages of the project. However, as the compactor operator became more comfortable with the material, most of these large objects were simply pushed into the fill and presented no problems. In all, two truck tires were punctured by foreign objects during construction.

One of the early problems with the WFS was dust control. In general, the WFS arrived on site at a water content within the required range for compaction (12-15\%). If it was compacted quickly, little watering was necessary to reach OMC or to control dust. However, the WFS dried quickly in direct sunlight and when transported in uncovered trucks, resulting in a dust control problem. The contractor solved this problem by watering the top of the embankment regularly and instructing drivers to keep their trucks covered during transport. In addition to the dust control problem, silt fences were needed around the embankment to catch fines that washed off the fill. This would be especially important if WFS were used in a populated area. Overall, the WFS compacted well. During construction, there was no observable "pumping" or "rutting" of the compacted WFS under heavy construction equipment, such as large cranes. 
- 


\section{CHAPTER 6: CONCLUSIONS AND RECOMMENDATIONS}

\subsection{CONCLUSIONS}

This report presents laboratory and field test data describing the geotechnical properties of weathered and fresh waste foundry sand (WFS) and the geotechnical performance of a highway embankment constructed using weathered WFS. The WFS used for this project came from Aubum Foundry, Inc. of Auburn, Indiana. The following conclusions were reached as a result of this study:

1. The geotechnical performance of the WFS was comparable to that of the clean natural sand, with small internal deformations and a high standard penetration resistance.

2. Dry unit weights of weathered WFS obtained in the field were in general agreement with standard and modified Proctor compaction curves using the Method B procedure. Limited test data using the Method A procedure did not agree as well with field measurements.

3. Moisture contents obtained using the Speedy Moisture Meter compared well to those obtained from oven-dry samples. Dry unit weights obtained using the nuclear density gauge showed small errors $(\leq 3 \%)$ when compared to those obtained using the sand cone method. This can probably be attributed to differences in measured moisture contents for the nuclear density gauge and Speedy Moisture Meter.

4. As a result of weathering, lower fines contents were measured in WFS samples taken from the top of the monofill. The amount of fines in WFS may affect the strength, hydraulic conductivity, and compaction characteristics of the material. 
5. Laboratory and field tests indicated the hydraulic conductivity for compacted WFS ranged from $1 \times 10^{-8}$ to $7 \times 10^{-7} \mathrm{~m} / \mathrm{s}$. In this study, compacted weathered WFS was not considered a free-draining material.

6. WFS dust was controlled during construction by frequent watering of the working surface. Possible damage to construction equipment due to foreign objects in the WFS was initially a concern for this project. However, damage was minimal once the contractor became familiar with the material.

7. The laboratory and field data presented in this paper are applicable specifically to WFS obtained from a single stockpile. WFS properties will vary depending on the foundry product, casting and recycling processes, storage method, and field construction methods. Appropriate testing is needed for each proposed WFS material. In addition, environmental testing may be required in order to satisfy regulatory requirements.

\subsection{RECOMMENDATIONS}

1. Use standard material tests to determine the geotechnical properties of WFS. These tests should be performed on representative samples of the WFS material to be used for construction. Weathering can significantly change the properties of fresh WFS. When appropriate, use method B Proctor compaction tests for WFS to account for large particles.

2. Compact WFS using heavy equipment which imparts a kneading action to the surface. Smooth drum and smooth drum vibratory rollers were found to be relatively ineffective for compacting WFS in the field. Control dust by frequent watering of the compaction surface.

3. Use the sand cone method and Speedy Moisture Meter for field compaction testing of WFS until adequate corrections can be developed for nuclear density gauge testing.

4. Foundry operators should make efforts to limit the amount of foreign objects and bag house dust in WFS prior to use in construction. 


\section{REFERENCES}

ASTM. (1998). Annual Book of ASTM Standards. Volume 04.08, American Society for Testing and Materials, West Conshohocken, PA.

Bowles, J. E. (1992). Engineering Properties of Soils and Their Measurement. McGrawHill, Inc., New York, NY.

Das, B. M. (1994). Principles of Geotechnical Engineering, PWS-Kent, Boston, MA.

INCMA. (1992). Indiana Cast Metals Association, Foundry Survey of 1991.

Javed, S., Lovell, C. W., and Hollenbeck, D. (1994). "Spent Foundry Sand and its Uses in Civil Engineering", Proceedings, Third Int. Conf. on Envir. Issues and Waste Man. in Energy and Mineral Production, Brodie-Hall Research \& Consultancy Centre Pty. Ltd., Perth, Western Australia, Cuirtin University of Technology, 541-556.

Javed, S. and Lovell, C. W. (1994). Use of Waste Foundry Sand in Highway Construction. Report JHRP/INDOT/FHWA-94/2J Final Report. School of Civil Engineering, Purdue University, West Lafayette, $\mathbb{I N}$.

Lovejoy, M. A., Ham, R. K., Traeger, P. A., Wellander, D., Hippe, J., and Boyle, W. C. (1996). "Evaluation of Selected Foundry Wastes for Use in Highway Construction," Proceedings, $19^{\text {th }}$ Int. Madison Waste Conf., Madison, WI, 19-31.

Mast, D. G. (1997). "Field Demonstration of a Highway Embankment Using Waste Foundry Sand," Master of Science Thesis, School of Civil Engineering, Purdue University, West Lafayette, IN.

Partridge, B., and Alleman, J. (1998). Field Demonstration of Highway Embankment Constructed Using Waste Foundry Sand, Joint Transportation Research Program, Final Report, FHWA/IN/JTRP-98-8, Purdue University, West Lafayette, IN.

Peck, R. B., Hanson, W. E., and Thornburn, T. H. (1974). Foundation Engineering. John Wiley \& Sons, New York, NY.

Terzaghi, K., and Peck, R. B. (1948). Soil Mechanics in Engineering Practice. John Wiley \& Sons, New York, NY.

Trautwein, S. J., and Boutwell, G. P. (1994). "In Situ Hydraulic Conductivity Tests for Compacted Soil Liners and Caps," Hydraulic Conductivity and Waste Contaminant Transport in Soil. ASTM STP 1142. D. Daniel and S. Trautwein, Eds., American Society for Testing and Materials, West Conshohocken, PA, 184-223.

"The Use of Foundry Sand in Highway Construction." (1994). Technical Summary, INDOT Division of Research, September 1994, West Lafayette, IN. 
- 


\section{APPENDIX}

INDOT SOIL BORING LOGS 
. 


\section{INDIANA DEPARTMENT OF TRANSPORTATION}

PROJECT NO. ST-9917 (A)

STRUCTUAE NO.

PROJECT LOCATION: NEW SR 206

STATION/OFFSET/LINE: $348+00 / \mathrm{CL} /$. "A"

BORING METHOD \& RIG TYPE: HSA / CME 45-B

WATER OEPTH I COMP. NA : AFTER - HRS.-

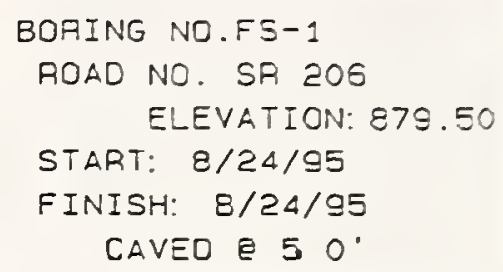

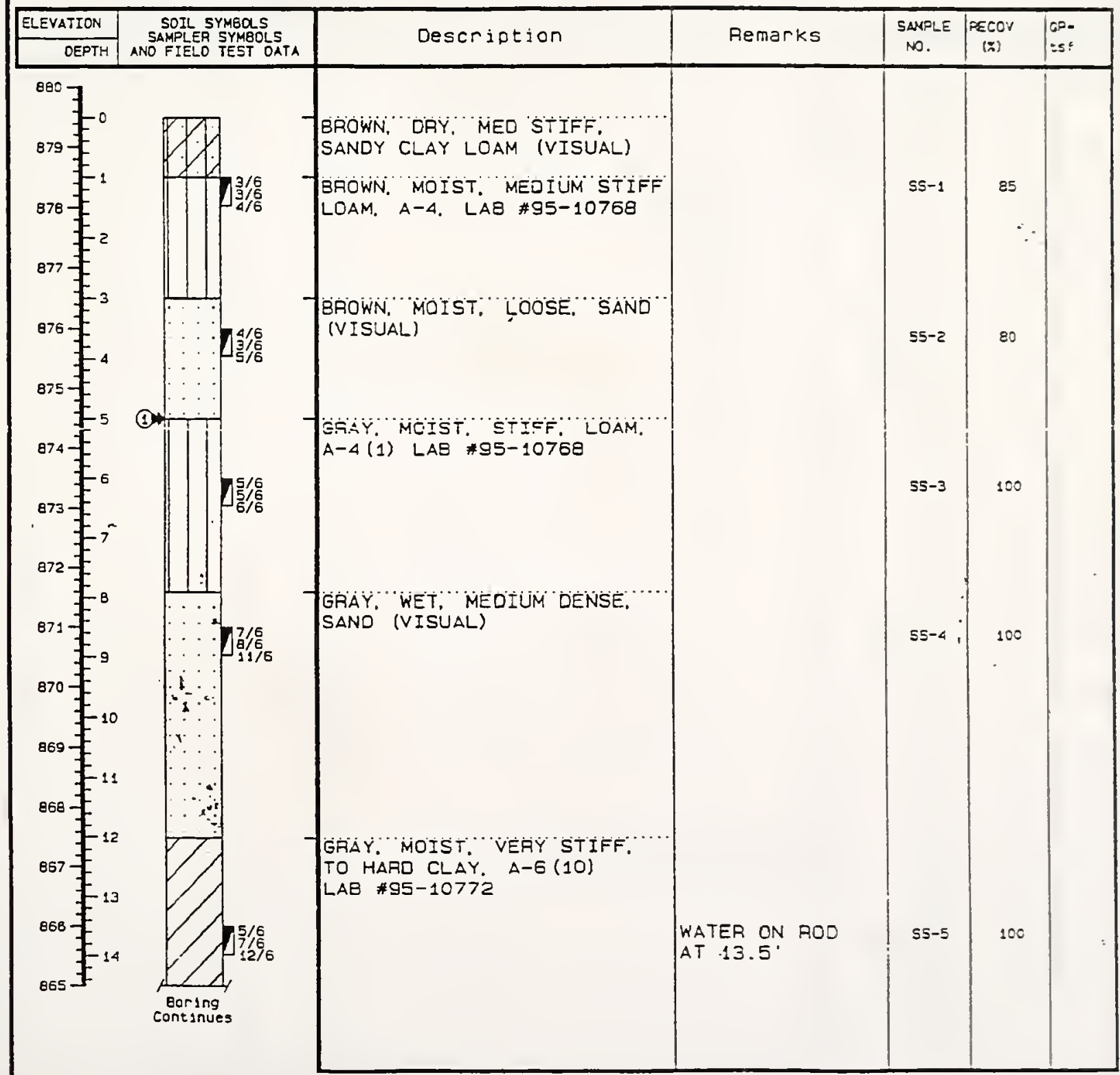

DRILLER: DENNIS TORRANCE

WEATHER: CLOUDY
INSPECTOR: DENNIS TORRANCE TEMPERATURE: $87 \mathrm{~F}$
DATUM: USCEGS

PAGE OF 


\section{INDIANA DEPARTMENT OF TRANSPORTATION}
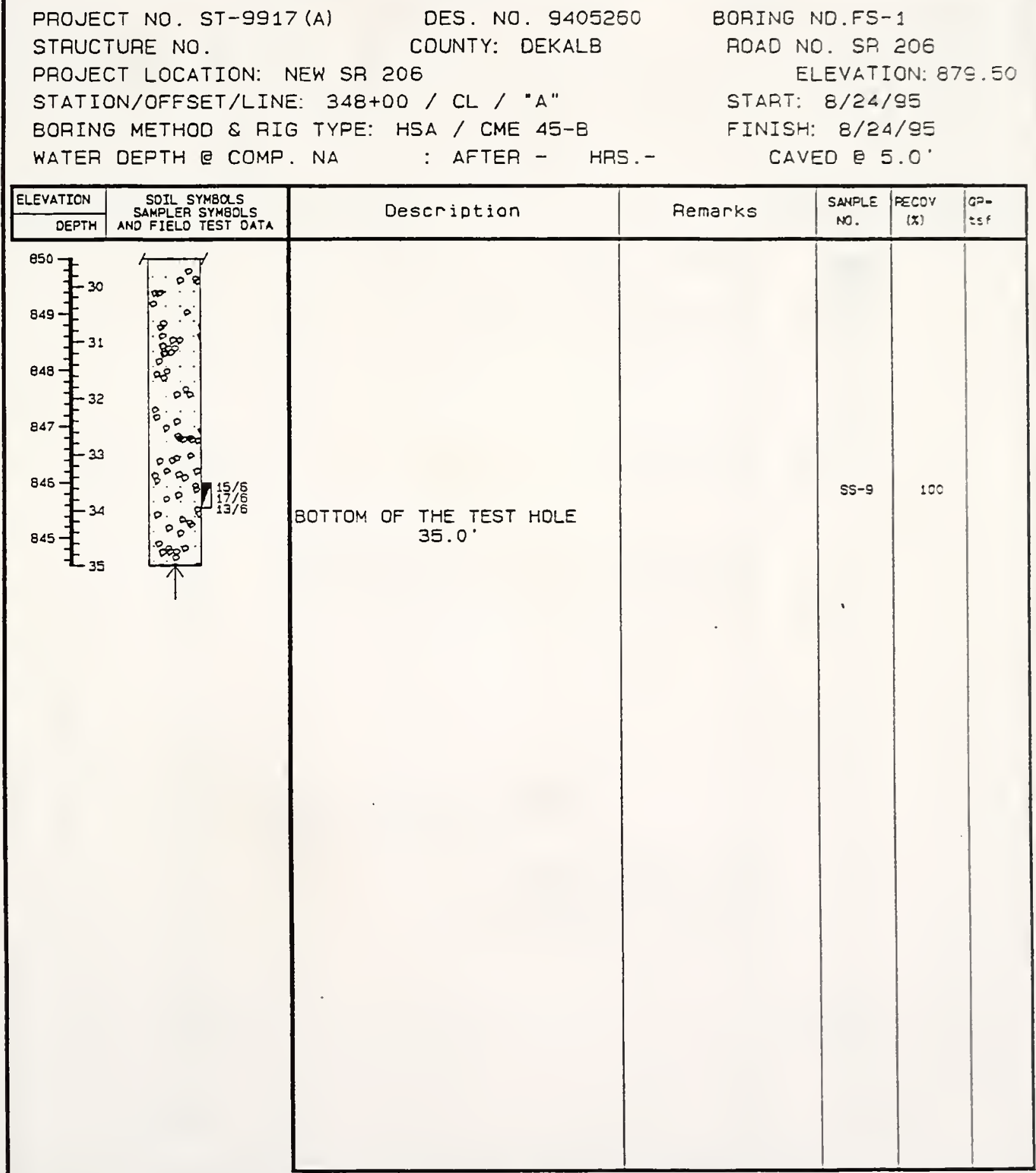

DRILLER: DENNIS TORFANCE WEATHER: CLOUDY
INSPECTOA: DENNIS TORRANCE

TEMPEAATURE: $87 \mathrm{~F}$
DATUM: USCEES

PAGE OF 


\section{INDIANA DEPARTMENT OF TRANSPORTATION}

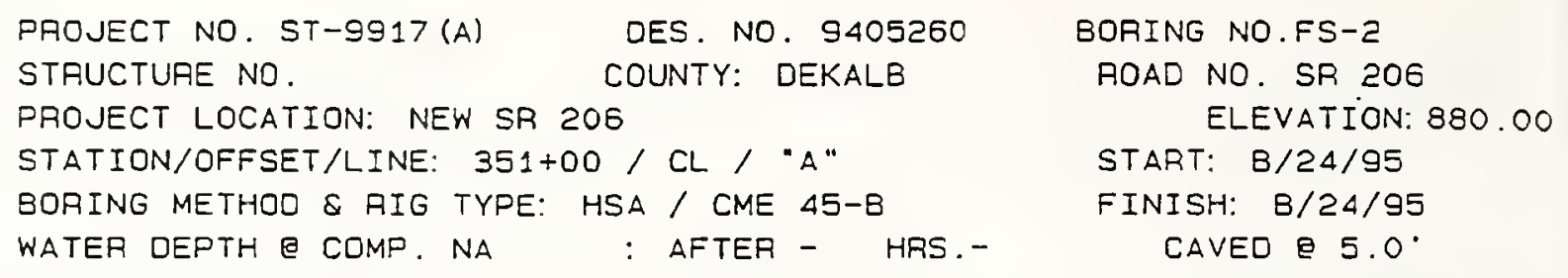

DES. NO. 9405260

COUNTY: DEKALB

PROJECT LOCATION: NEW SR 206

STATION/OFFSET/LINE: $351+00 / \mathrm{CL} /$ "A"

BORING METHOD \& RIG TYPE: HSA / CME 45-B

WATER DEPTH E COMP. NA : AFTER - HRS.-

\author{
BORING NO.FS-2 \\ AOAD NO. SR 206 \\ ELEVATION: 880.00 \\ START: $B / 24 / 95$ \\ FINISH: $B / 24 / 95$ \\ CAVEO $95.0^{\circ}$
}

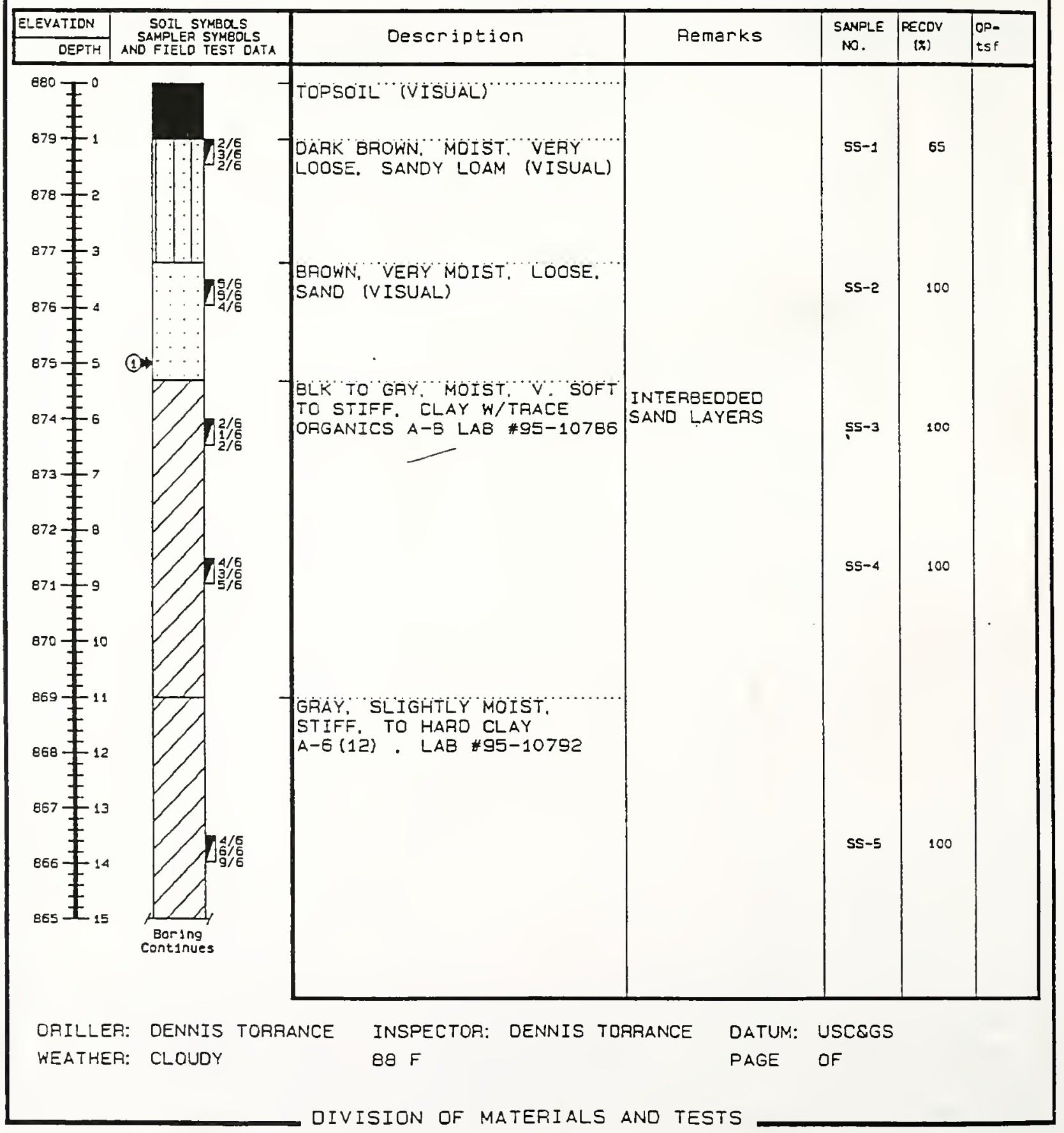




\section{INDIANA DEPARTMENT OF TRANSPORTATION}

PAOJECT NO. ST-9917 (A)

STRUCTURE NO.

PROJECT LOCATION: NEW SR 206

STATION/OFFSET/LINE: $351+00$ / CL / "A"

BOAING METHOD \& RIG TYPE: HSA / CME 45-B

WATER DEPTH E COMP. NA

\author{
DES. NO. 9405260 \\ COUNTY: DEKALB
}

: AFTER - HFS.-

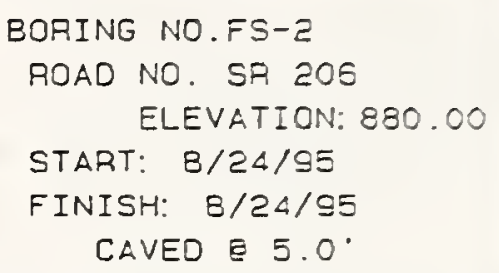

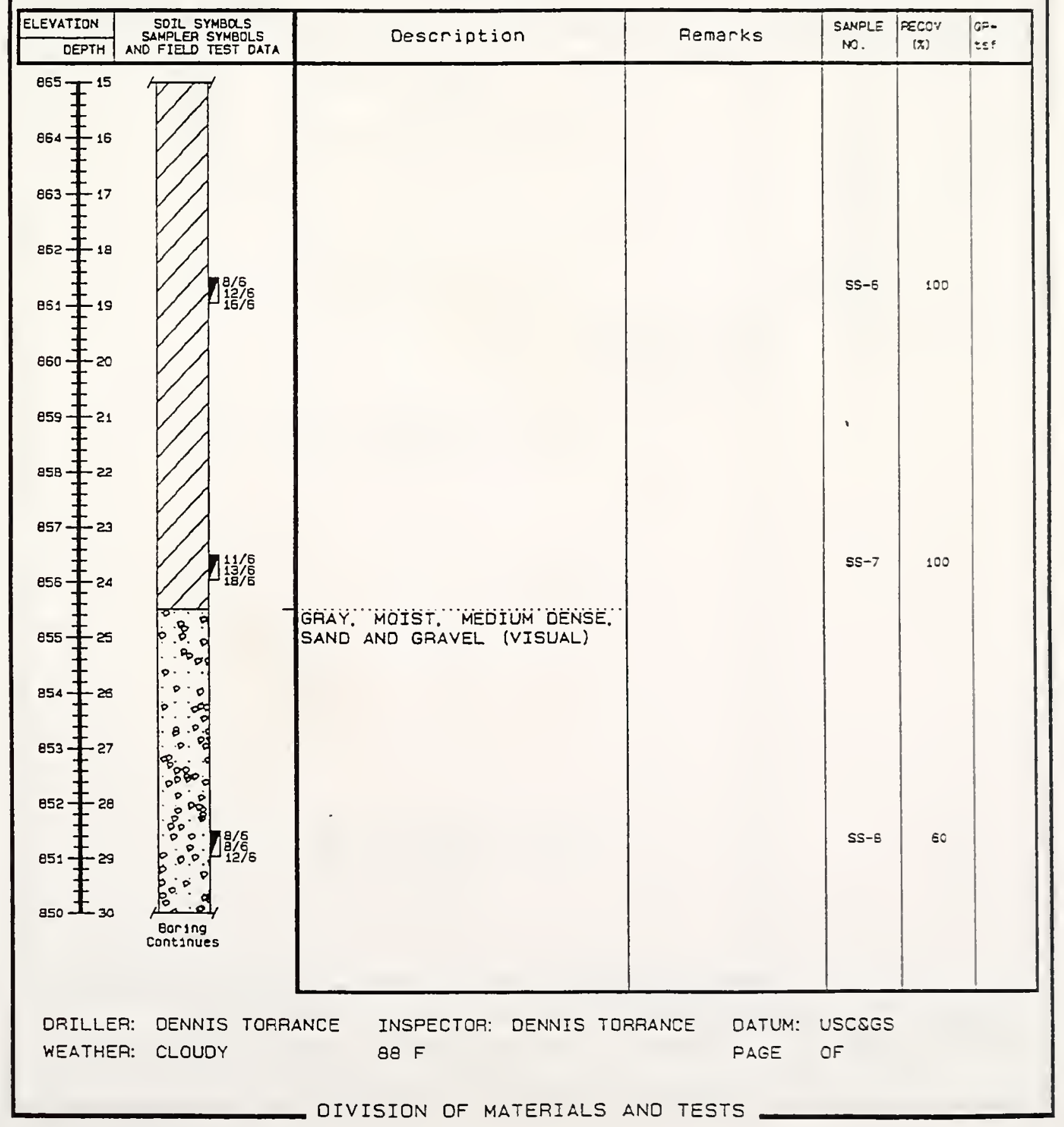




\section{INDIANA DEPARTMENT OF TRANSPORTATION}
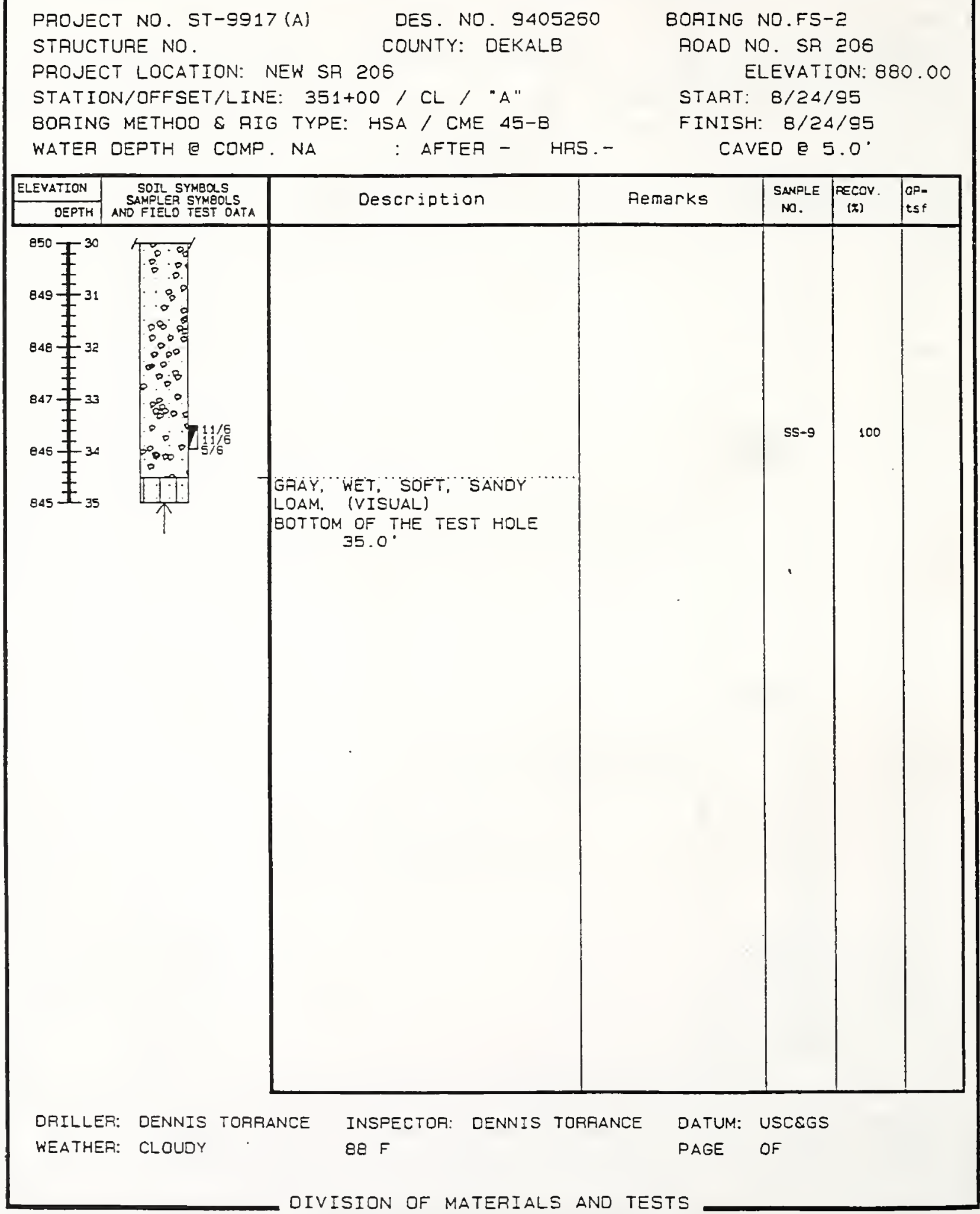


\section{INDIANA DEPARTMENT OF TRANSPORTATION}

PROJECT NO. ST-9917(A)

STAUCTUAE NO.

PROJECT LOCATION: NEW SR 206 IN DEKALB COUNTY STATION/OFFSET/LINE: $350+00 / \mathrm{CL} /$ "A"

BORING METHOD \& RIG TYPE: HSA / TRUCK

WATER DEPTH $E$ COMP. 15.0 $0^{\circ}$ : AFTER 24 HRS.5.5.

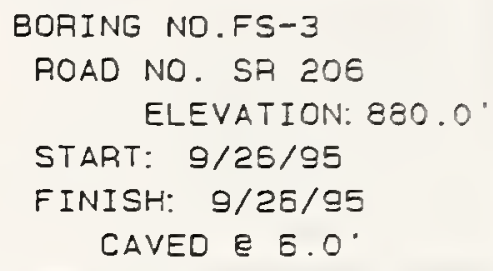

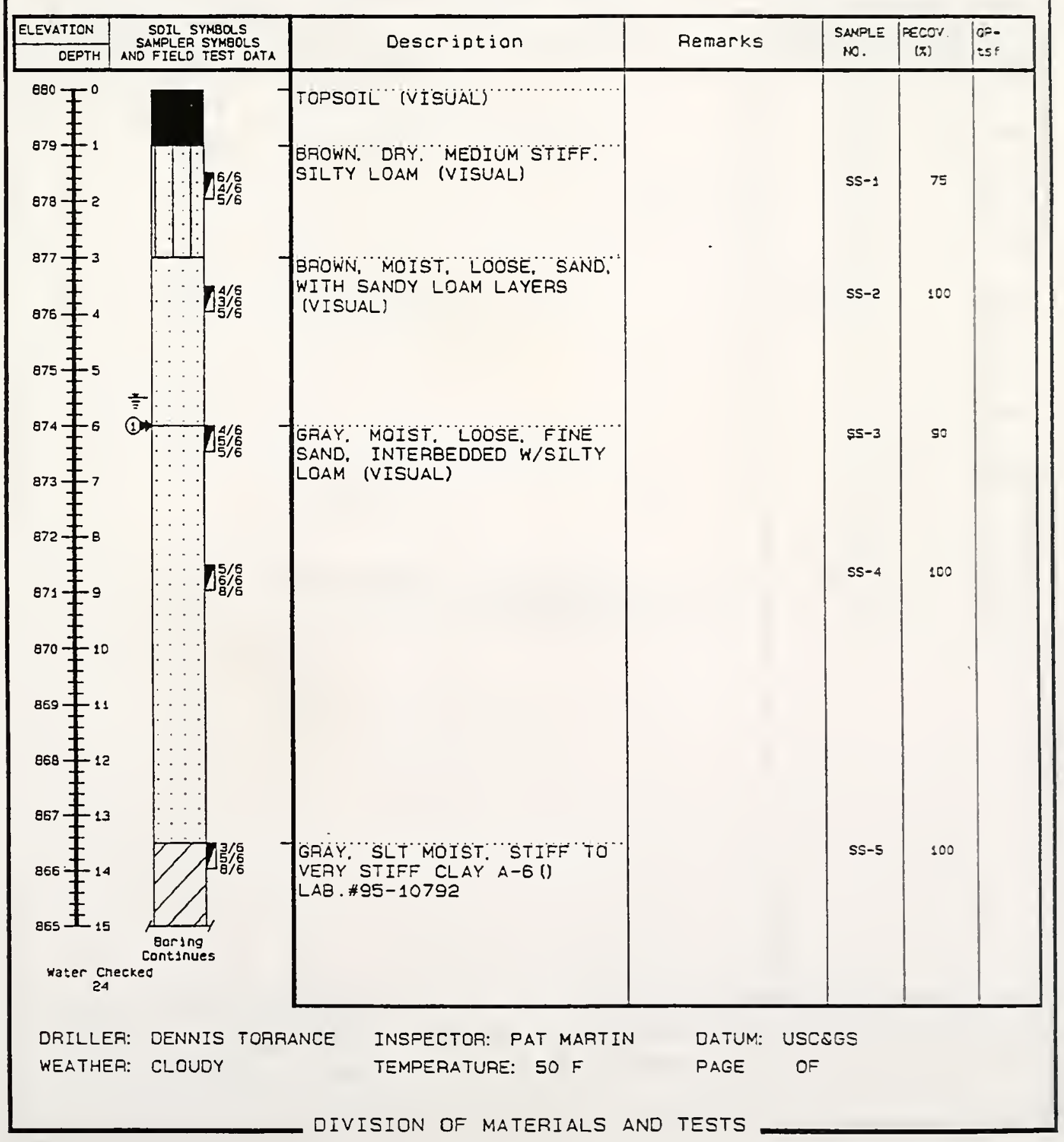




\section{INDIANA DEPARTMENT OF TRANSPORTATION}
PROJECT NO. ST-9917 (A)
DES. NO. 9405260
STRUCTURE NO. COUNTY: DEKALB
PROJECT LOCATION: NEW SR 206 IN DEKALB COUNTY STATION/OFFSET/LINE: $350+00 / C L /$ "A"
BORING METHOD \& RIG TYPE: HSA / TRUCK
WATER DEPTH E COMP. $15.0^{\circ}$ : AFTER 24 HRS.5.5.

\author{
BORING NO.FS-3 \\ AOAD NO. SR 206 \\ START: $9 / 26 / 95$ \\ FINISH: $9 / 26 / 95$
}
ELEVATION: $880.0^{\circ}$

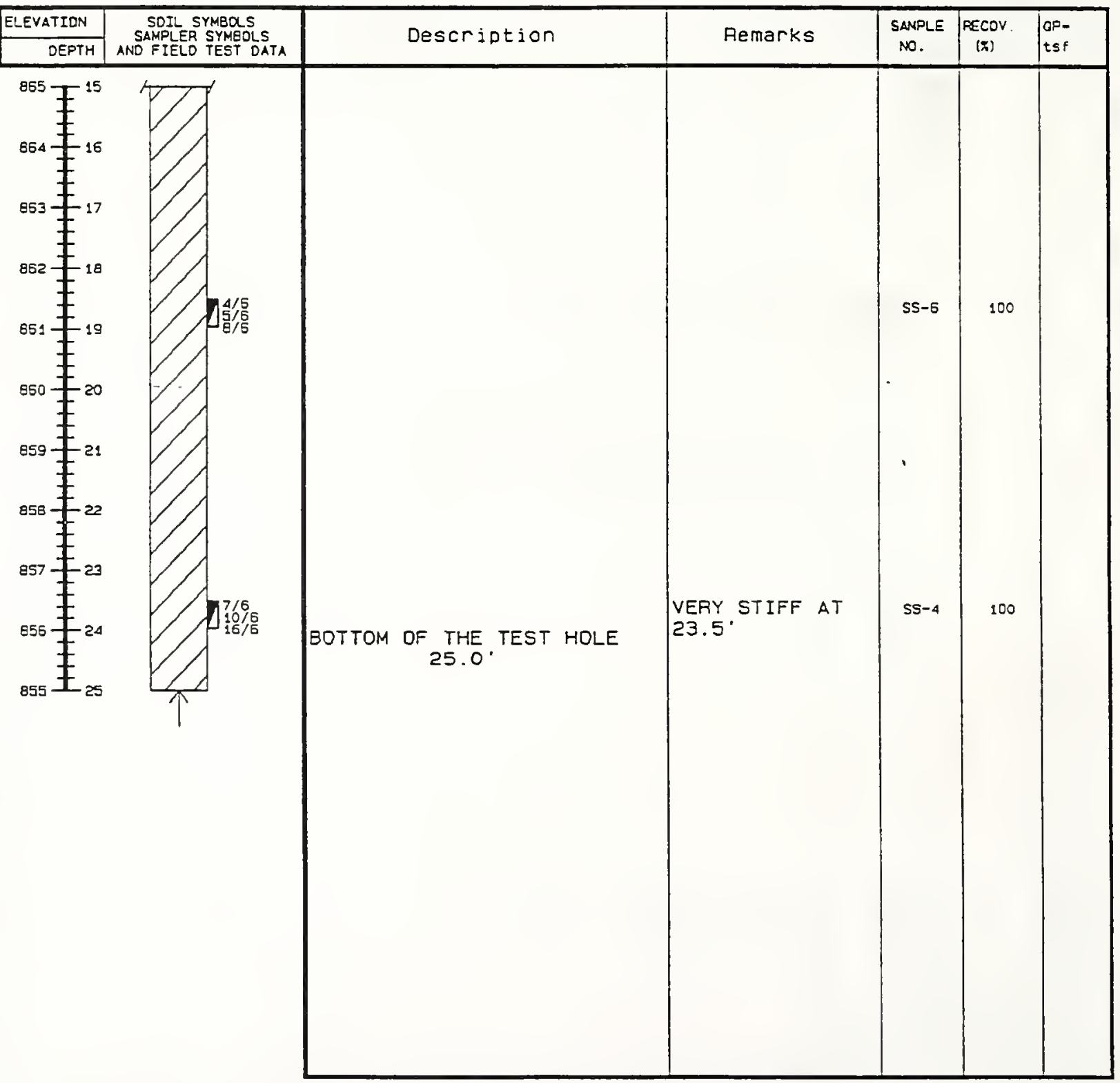

DRILLER: DENNIS TORRANCE

INSPECTOR: PAT MARTIN

DATUM: USCEGS

WEATHER: CLOUDY

TEMPERATURE: $50 \mathrm{~F}$

PAGE OF 


\section{INDIANA DEPARTMENT OF TRANSPORTATION}

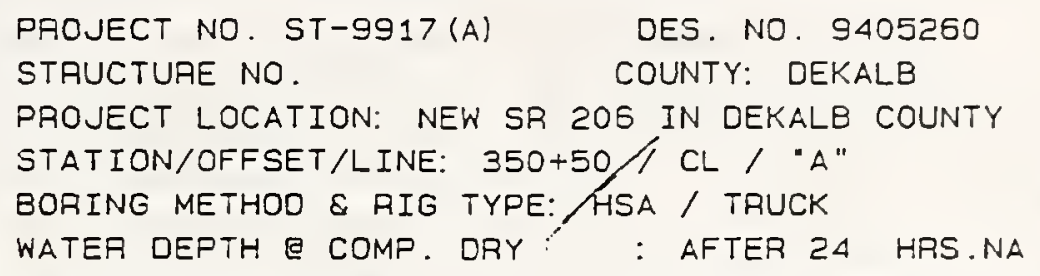

PROJECT LOCATION: NEW SR 206 IN DEKALB COUNTY

WATER DEPTH E COMP. DRY : : AFTER 24 HRS.NA

DES. NO. 9405260

COUNTY: DEKALB
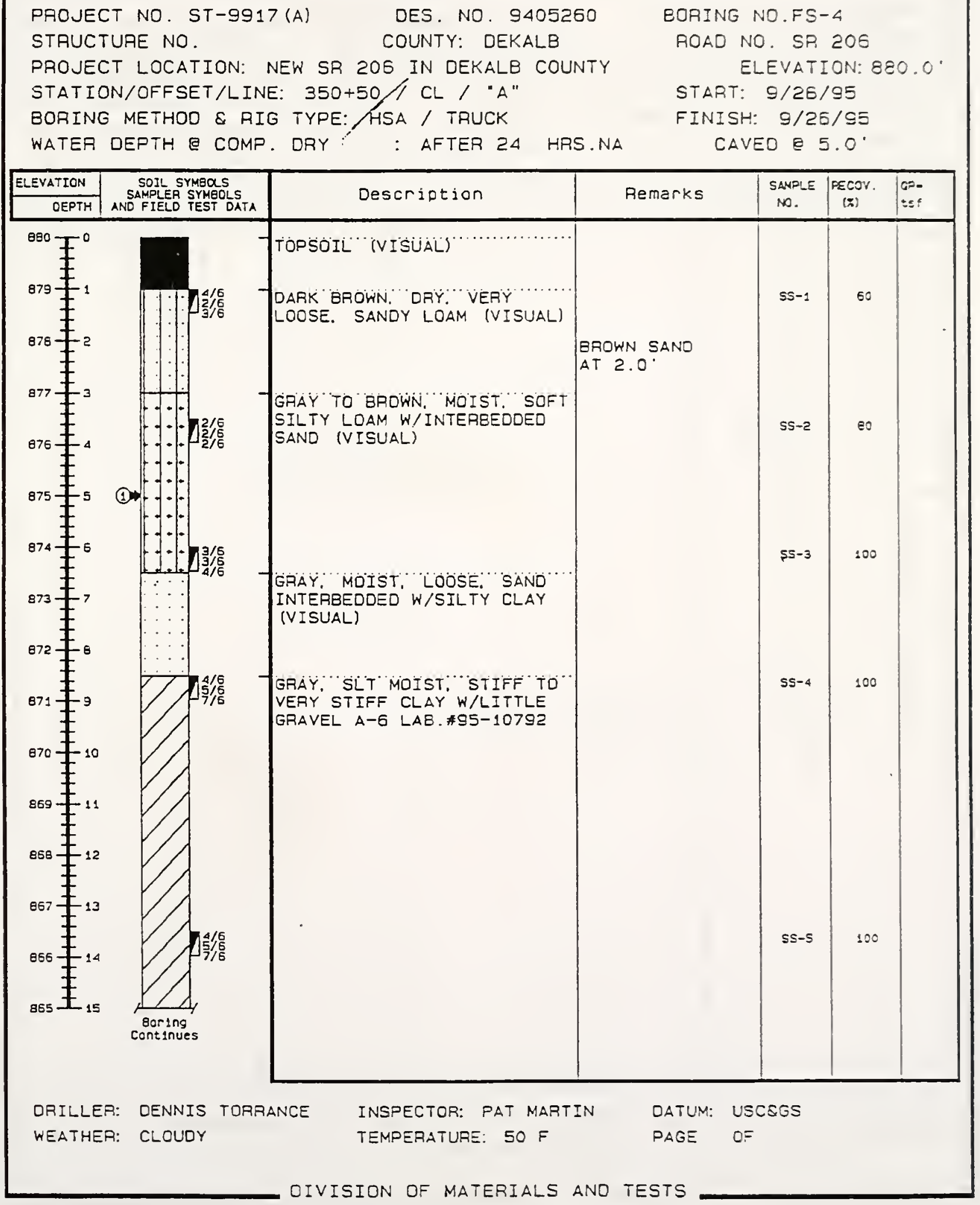


\section{INDIANA DEPARTMENT OF TRANSPORTATION}

PROJECT NO. ST-9917 (A) DES. NO. 9405250
STAUCTURE NO.

PROJECT LOCATION: NEW SR 206 IN DEKALB COUNTY STATION/OFFSET/LINE: $350+50 / \mathrm{CL} /$ "A"

BORING METHOO \& RIG TYPE: HSA / TRUCK

WATER OEPTH @ COMP. ORY : AFTEF 24 HRS.NA

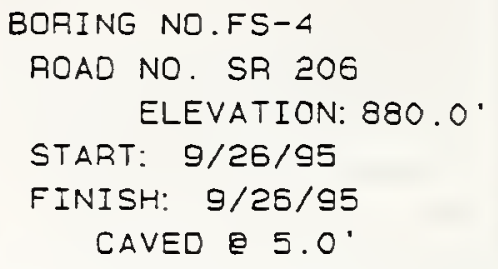

BORING NO.FS- 4

ROAD NO. SR 206

ELEVATION: $880.0^{\circ}$

START: $9 / 26 / 95$

FINISH: $9 / 25 / 95$

CAVED $5.0^{\circ}$

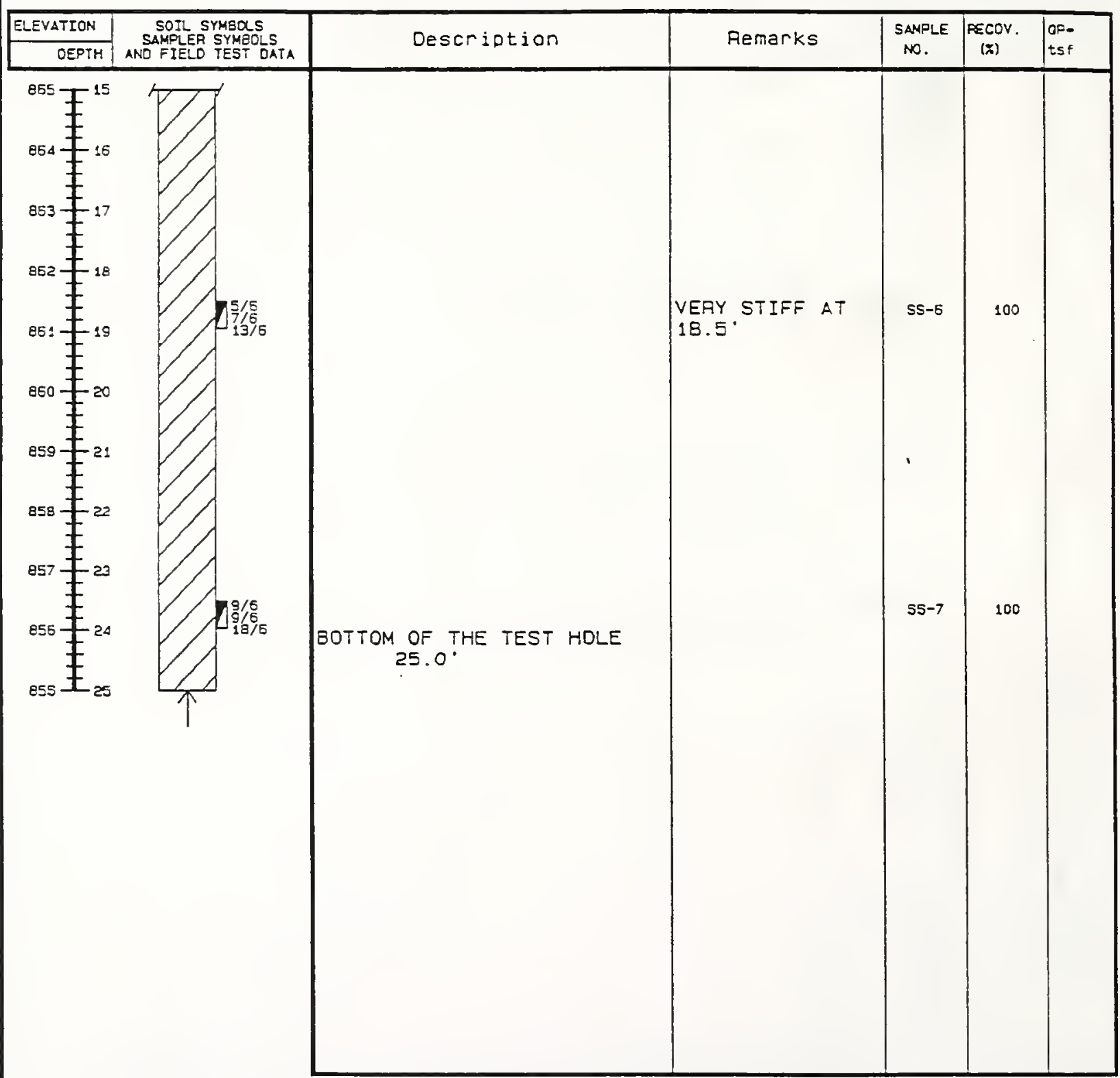

DRILLER: DENNIS TORRANCE WEATHER: CLOUDY
INSPECTOR: PAT MARTIN

TEMPERATURE: SO $\mathrm{F}$
DATUM: USCEGS

PAGE OF 


\section{INDIANA DEPARTMENT OF TRANSPORTATION}

PROJECT NO. ST-9917 (A)

STAUCTURE NO.

PROJECT LOCATION: NEW SR 206 IN DEKALB COUNTY STATION/OFFSET/LINE: $349+50 / \mathrm{CL} /$ "A" BORING METHOD \& AIG TYPE: HSA / TRUCK WATER DEPTH Q COMP. DRY : AFTEA 24 HRS.NA

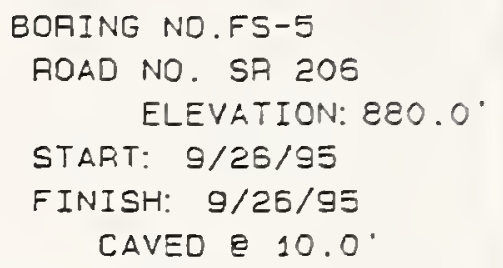

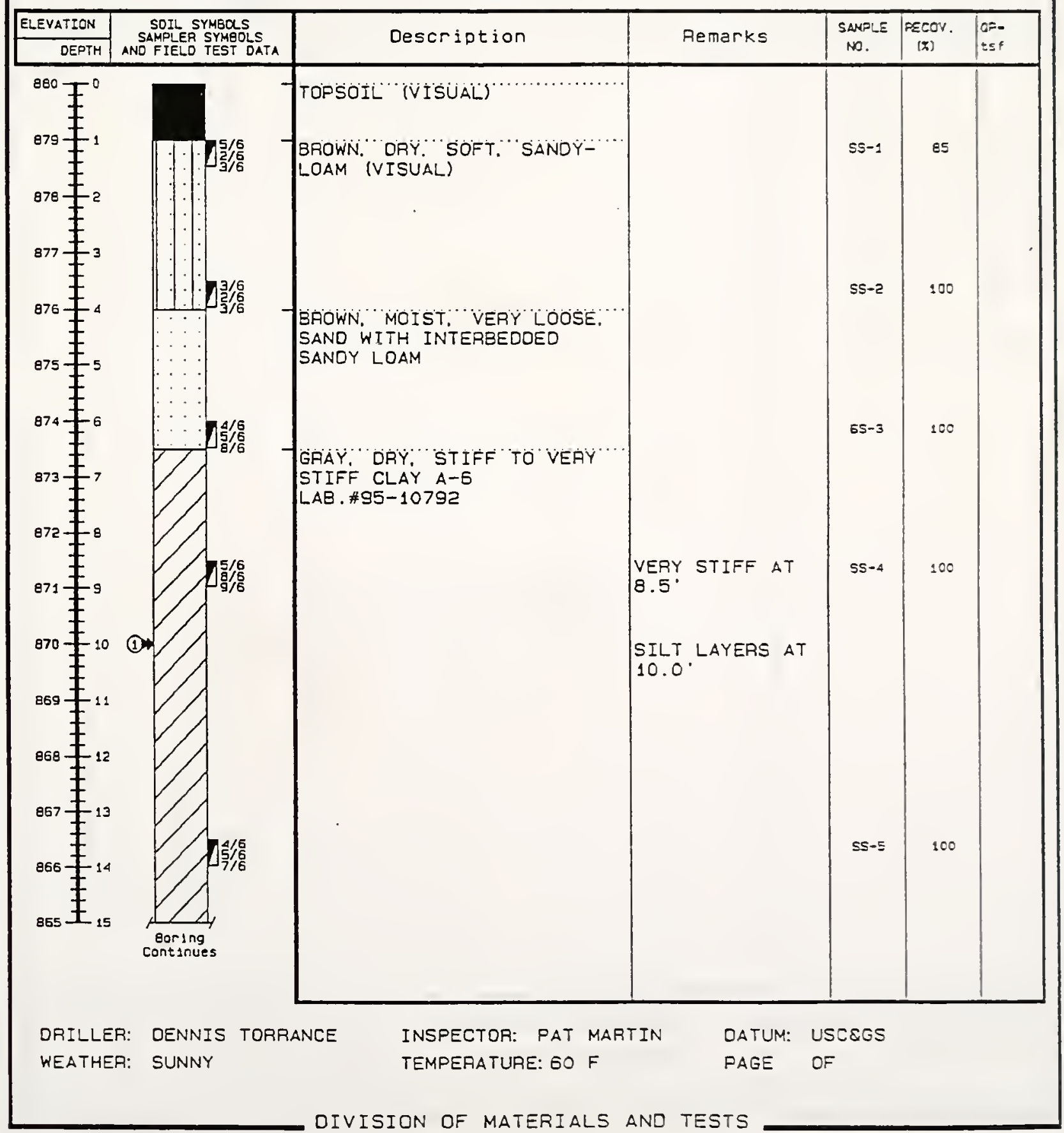




\section{INDIANA DEPARTMENT OF TRANSPORTATION}

PROJECT NO. ST-9917(A)

STAUCTURE ND.

DES. NO. 9405260

COUNTY: DEKALB

PROJECT LOCATION: NEW SR 206 IN DEKALB COUNTY

STATION/OFFSET/LINE: $349+50 / \mathrm{CL} /$ "A"

BORING METHOD \& RIG TYPE: HSA / TRUCK

WATER DEPTH E COMP. DRY : AFTER 24 HRS.NA

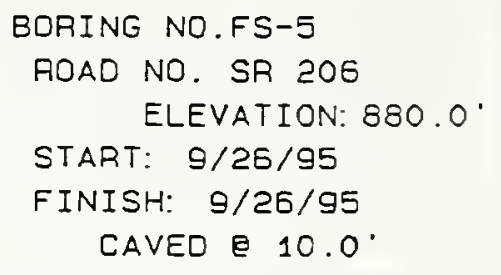

DRILLER: OENNIS TORRANCE

WEATHER: SUNNY
INSPECTOR: PAT MARTIN

TEMPERATURE: EO $F$
DATUM: USCEGS

PAGE OF 


\section{INDIANA DEPARTMENT OF TRANSPORTATION}

PROJECT NO. ST-9917 (A)

STRUCTURE NO.

PROJECT LOCATION: NEW SR 206 IN DEKALB COUNTY STATION/OFFSET/LINE: $352+00 / \mathrm{CL} /$ "A"

BORING METHOD \& RIG TYPE: HSA / TRUCK

WATER DEPTH E COMP. DRY : AFTER 24 HRS.NA

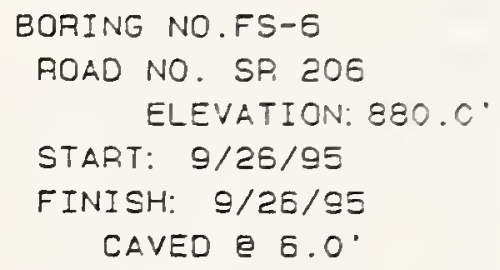

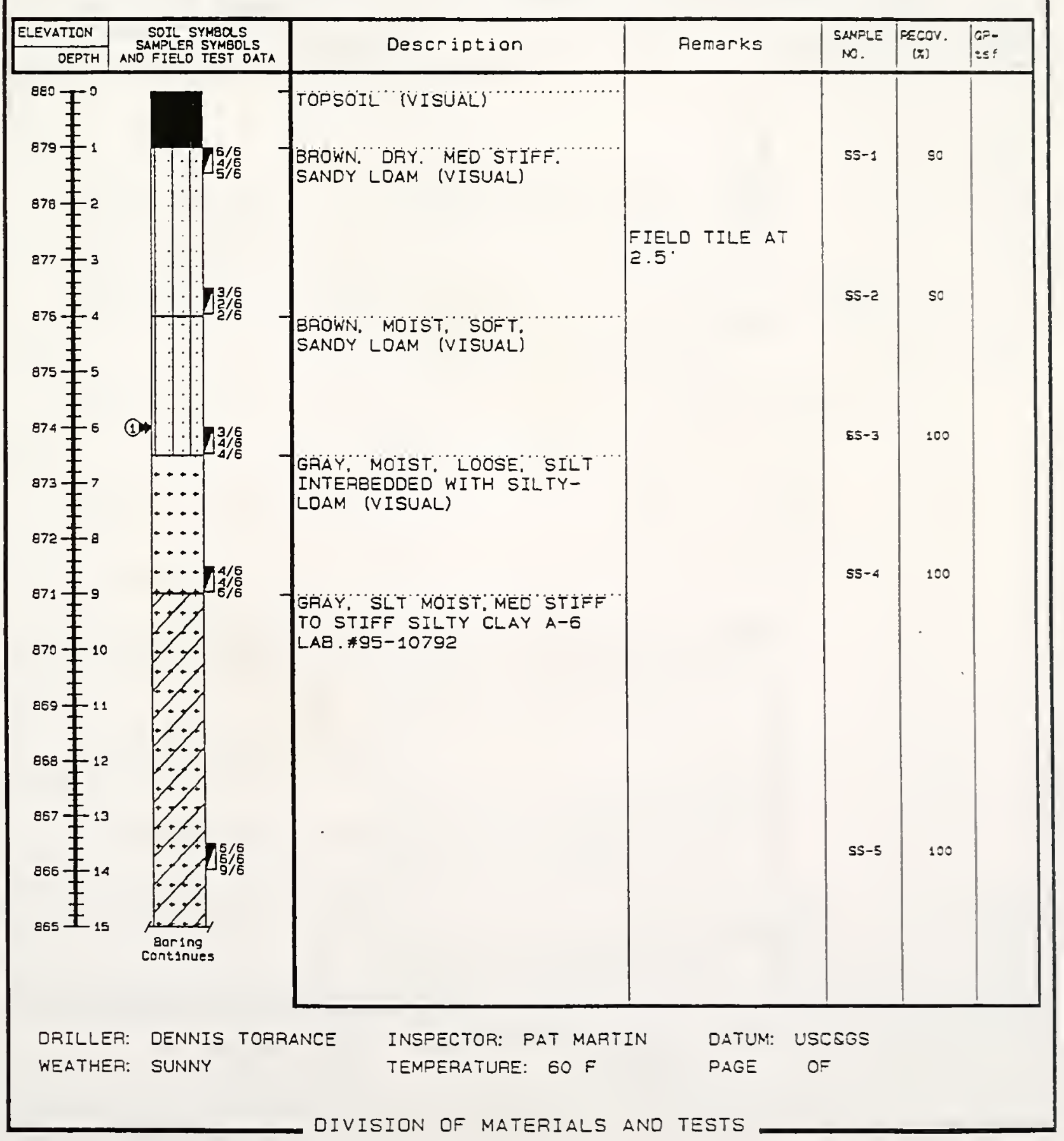




\section{INDIANA DEPARTMENT OF TRANSPORTATION}
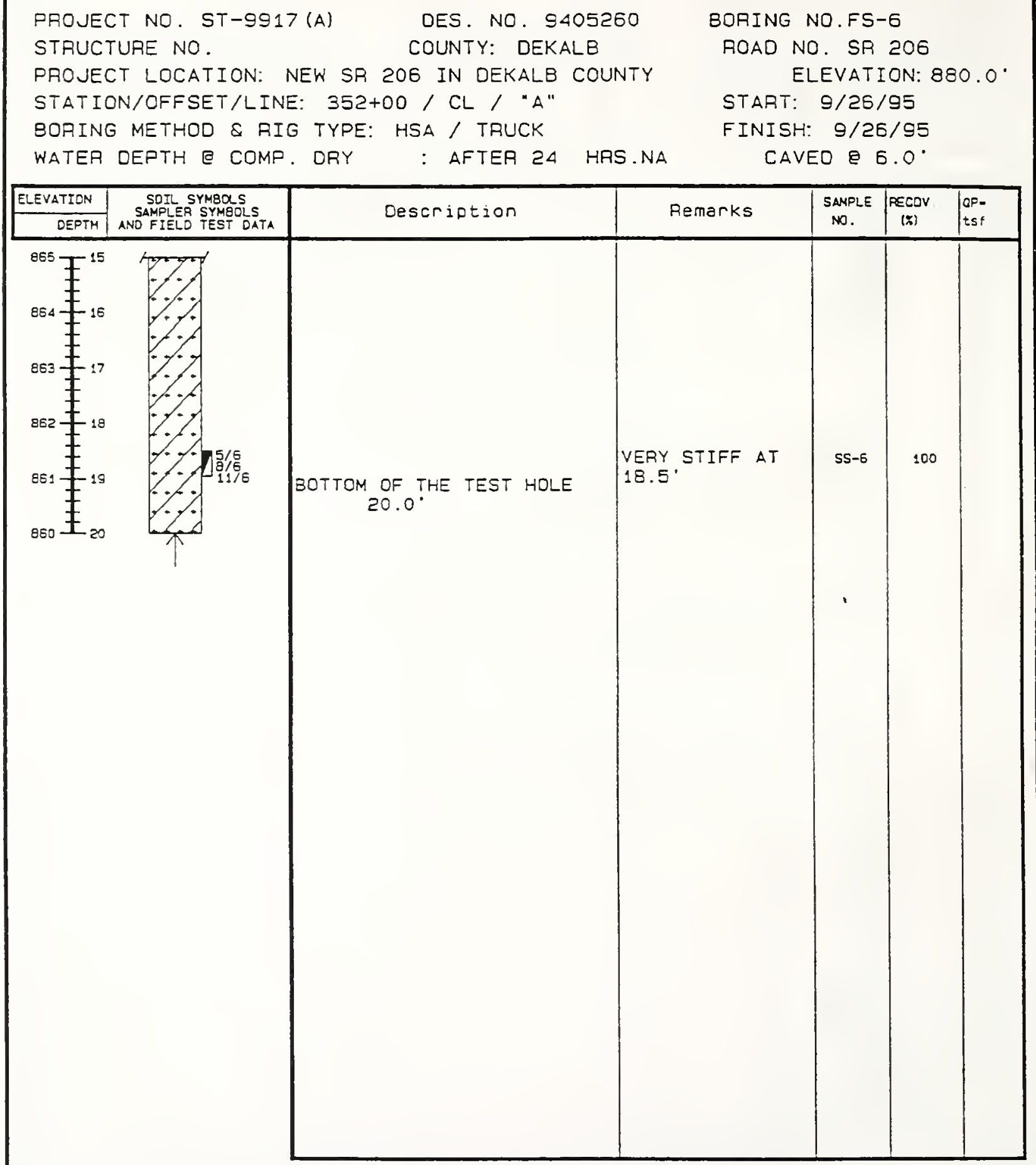

ORILLER: OENNIS TORRANCE

WEATHER: SUNNY
INSPECTOR: PAT MAATIN

TEMPERATURE: $60 \mathrm{~F}$
DATUM: USCEGS

PAGE OF 


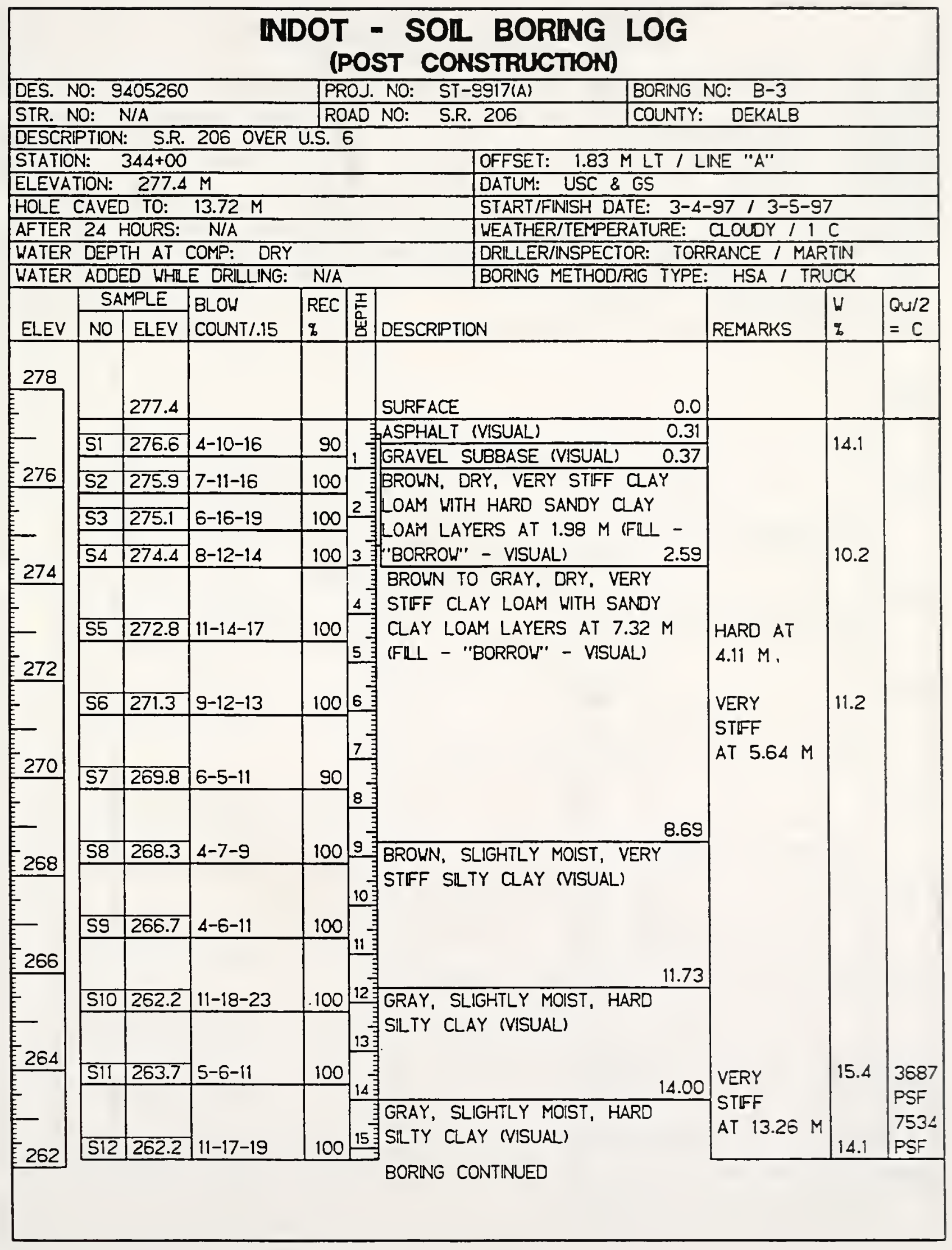




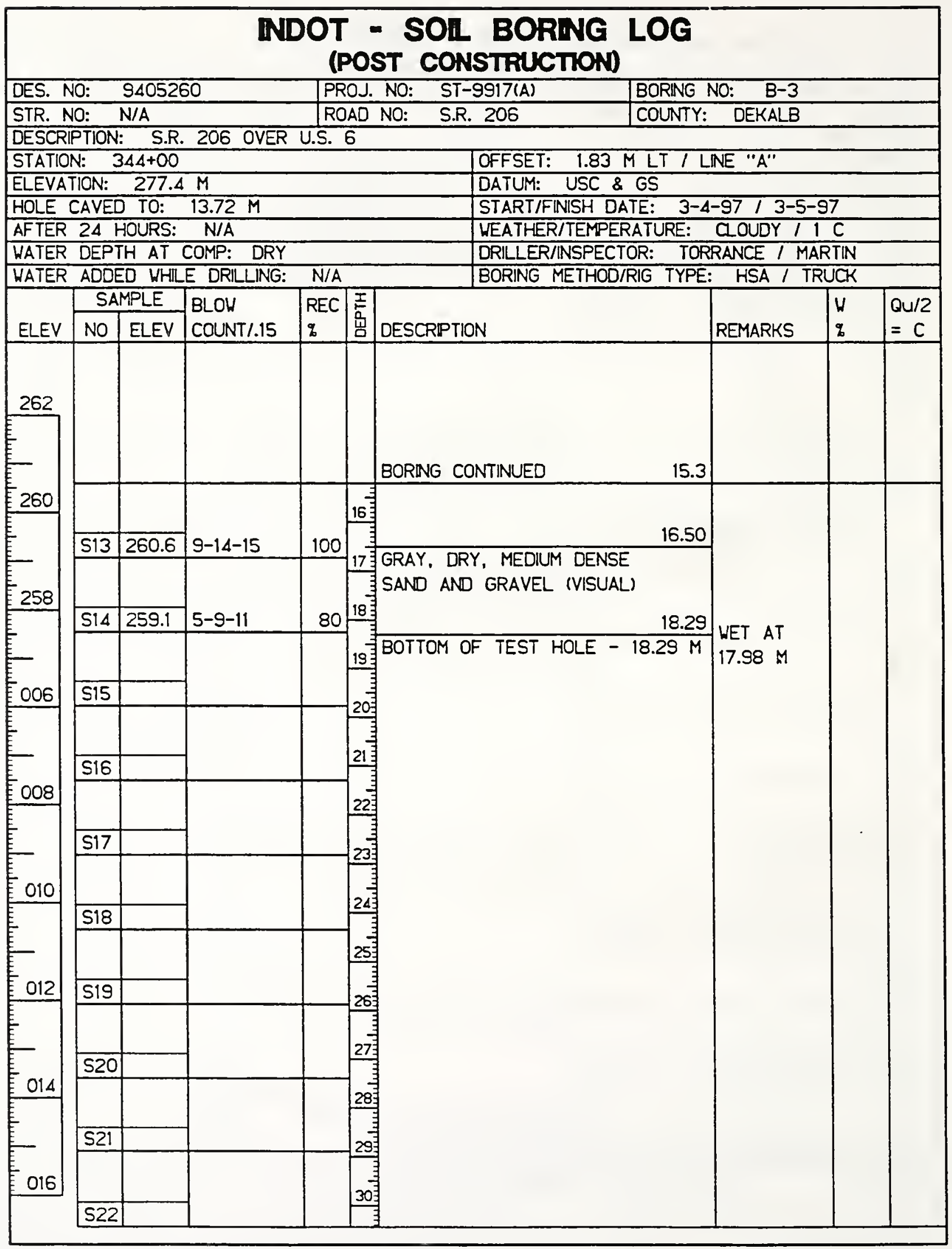




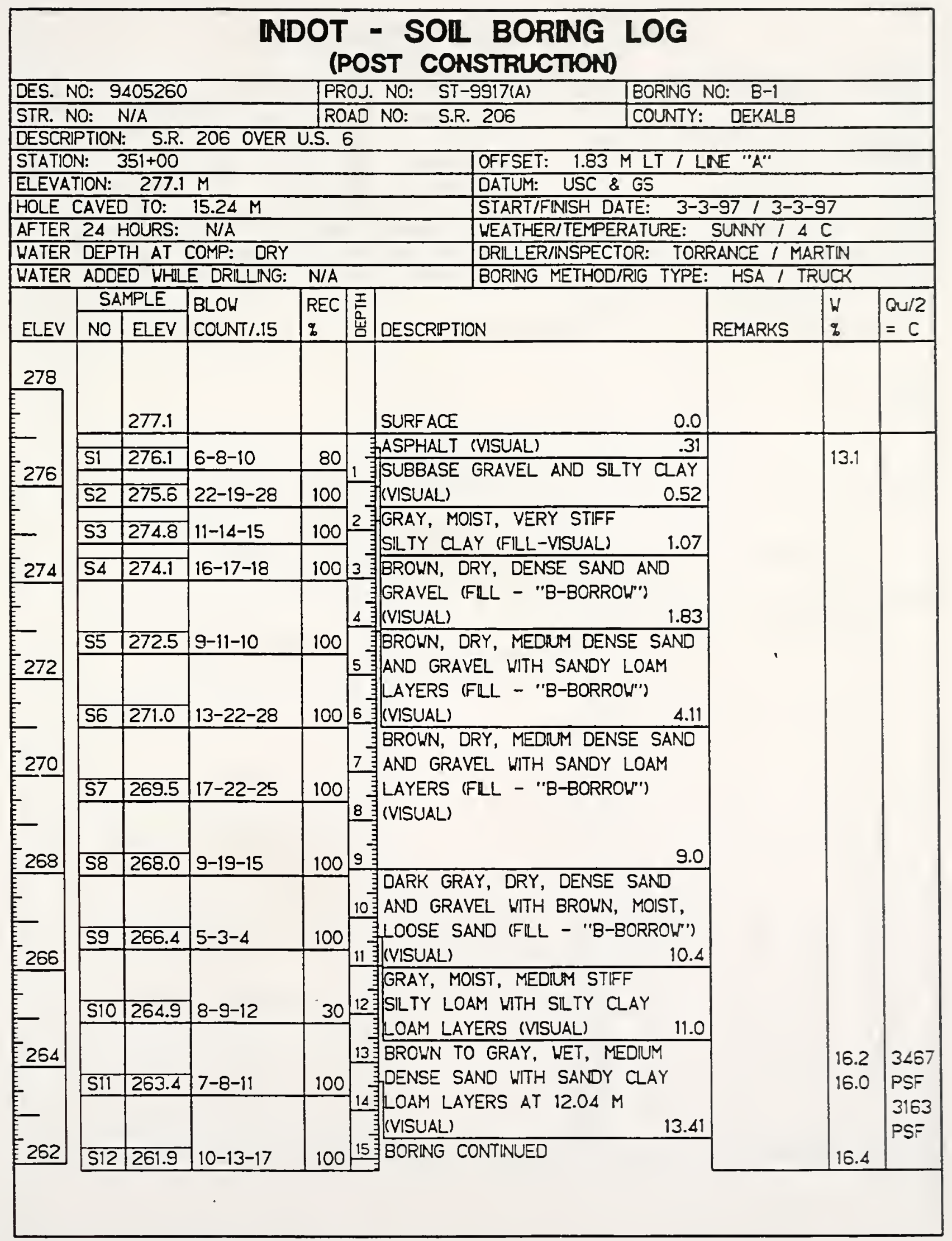




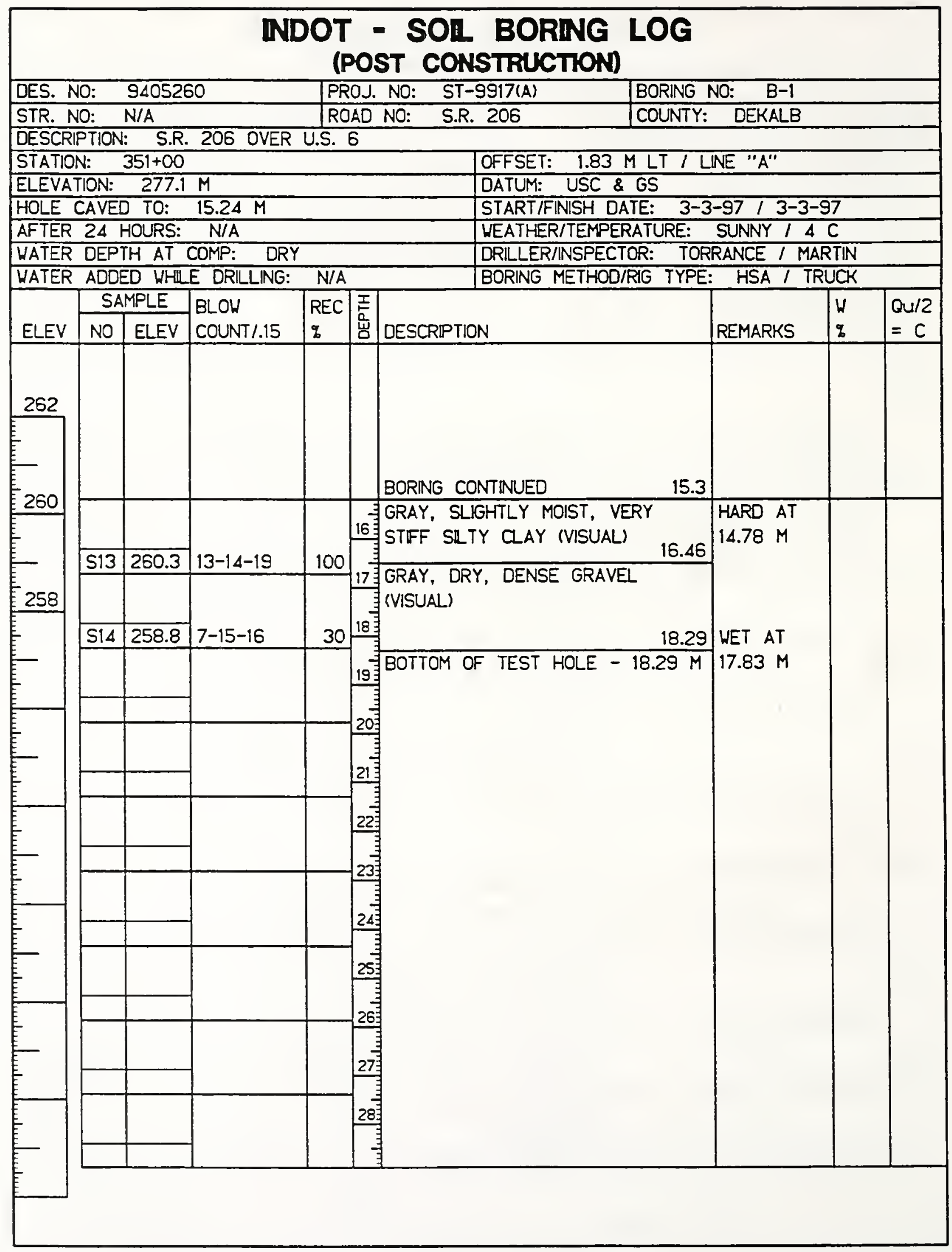




\section{INDOT - SOL BORING LOG \\ (POST CONSTRUCTION)}

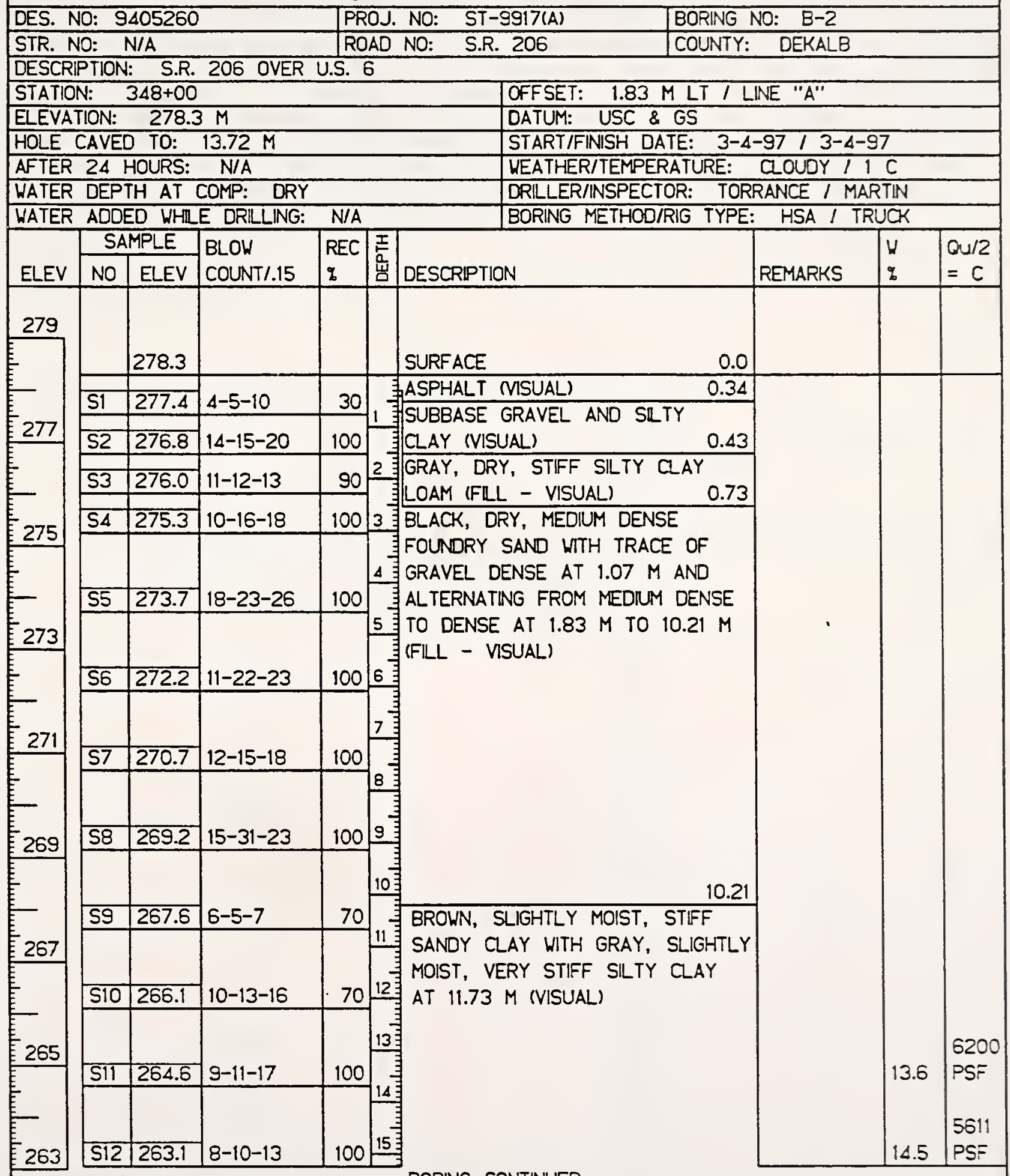




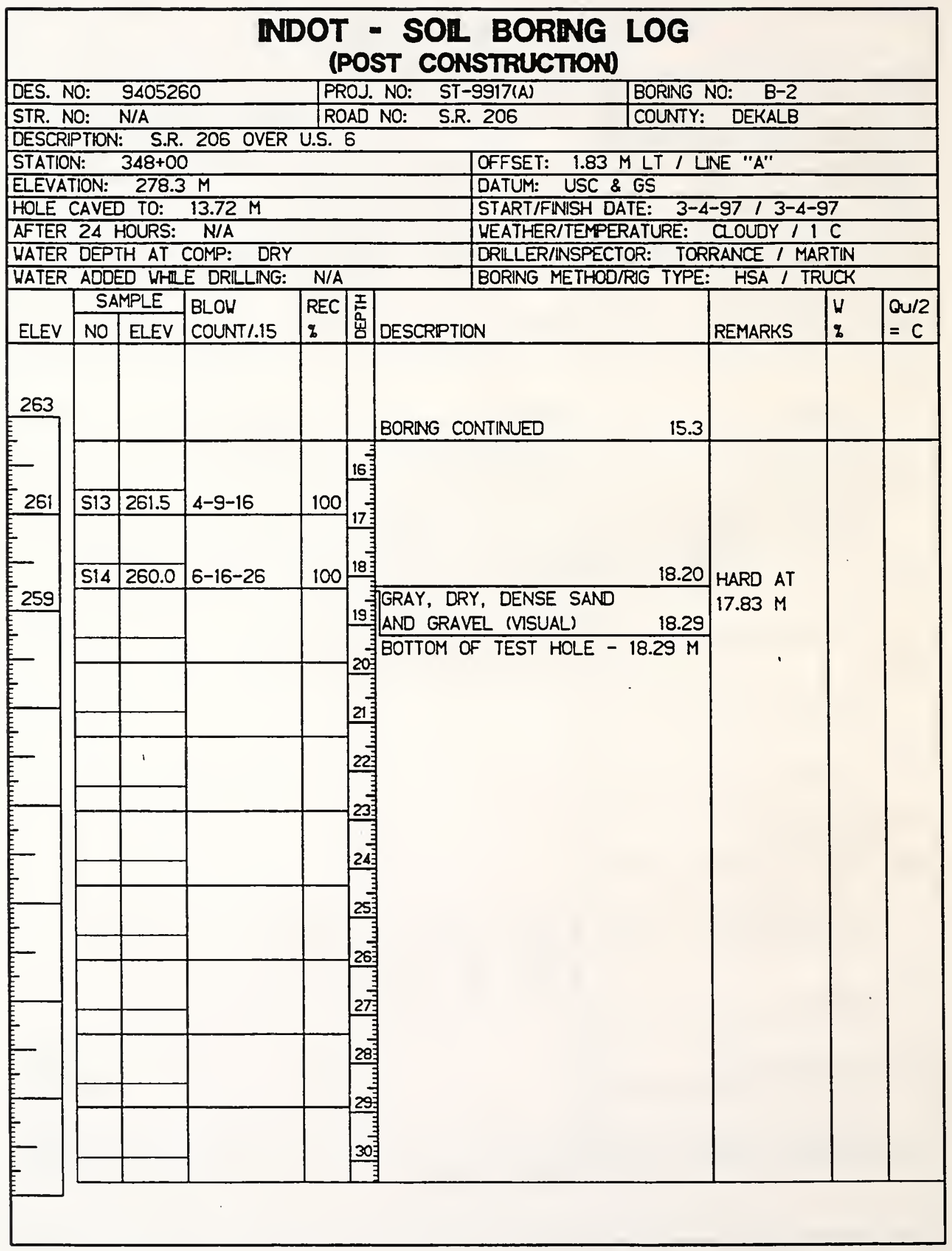



